THIAGO LOPES DA SILVA ARAUJO

\title{
DESEMPENHO DE REATOR ANAERÓBIO HÍBRIDO (LEITO FIXO E MANTA DE LODO) TRATANDO ESGOTO SANITÁRIO EM ESCALA PILOTO
}

Orientador: Prof. Tit. Eugenio Foresti

VERSÃO CORRIGIDA

São Carlos, SP

2014 



\section{DESEMPENHO DE REATOR ANAERÓBIO HÍBRIDO (LEITO FIXO E MANTA DE LODO) TRATANDO ESGOTO SANITÁRIO EM ESCALA PILOTO}

Dissertação apresentada à Escola de Engenharia de São Carlos, da Universidade de São Paulo, como parte dos requisitos para obtenção do título de Mestre em Ciências: Engenharia Hidráulica e Saneamento

Orientador:

Prof. Tit. Eugenio Foresti 
AUTORIZO A REPRODUÇÃO TOTAL OU PARCIAL DESTE TRABALHO, POR QUALQUER MEIO CONVENCIONAL OU ELETRÔNICO, PARA FINS DE ESTUDO E PESQUISA, DESDE QUE CITADA A FONTE.

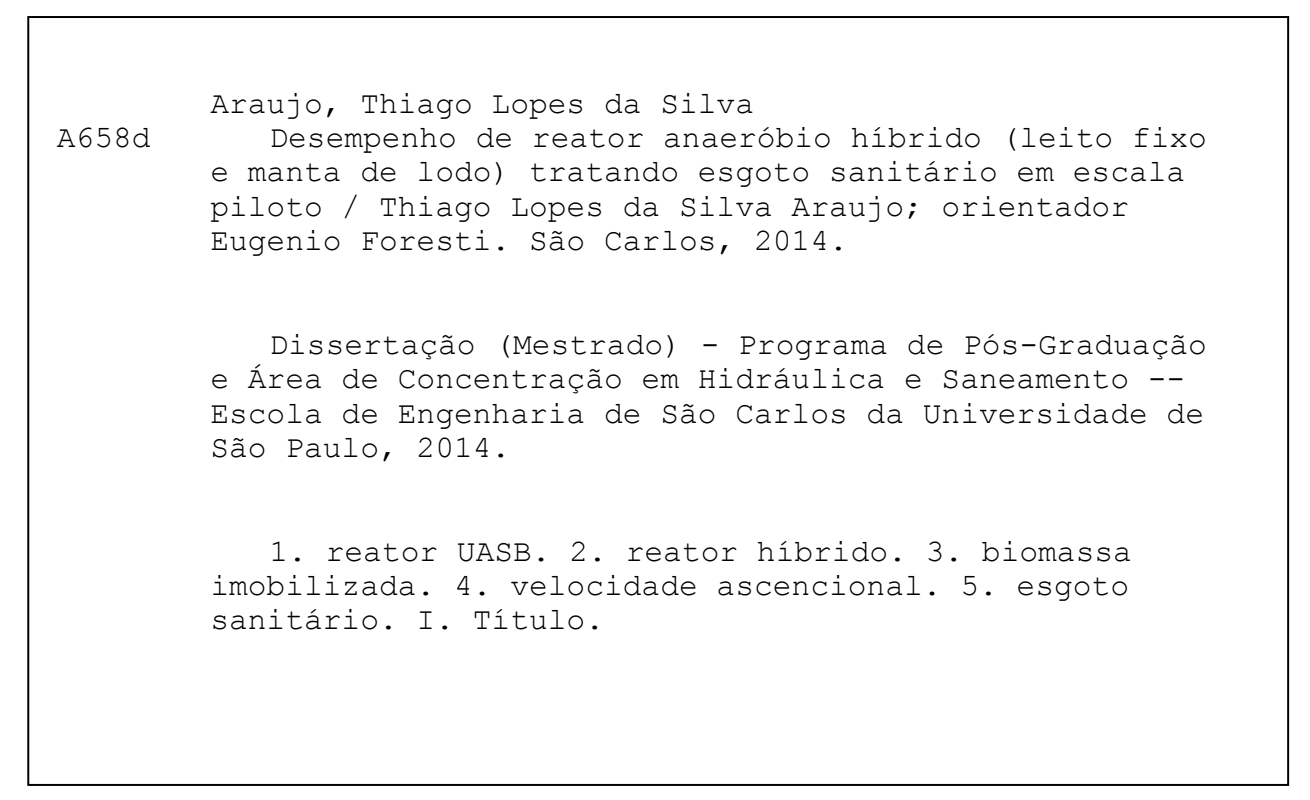




\section{FOLHA DE JULGAMENTO}

Candidato: Engenheiro THIAGO LOPES DA SILVA ARAÚJO.

Título da dissertação: "Desempenho de reator anaeróbio híbrido (leito fixo e manta de lodo) tratando esgoto sanitário em escala piloto".

Data da defesa: 09/06/2014

Comissão Julgadora:

Prof. Titular Eugenio Foresti (Orientador)

(Escola de Engenharia de São Carlos/EESC)

Profa. Dra. Márcia Helena R. Zamariolli Damianovic (Escola de Engenharia de São Carlos/EESC)

Prof. Dr. Carlos Augusto de Lemos Chernicharo

(Universidade Federal de Minas Gerais)
Resultado:
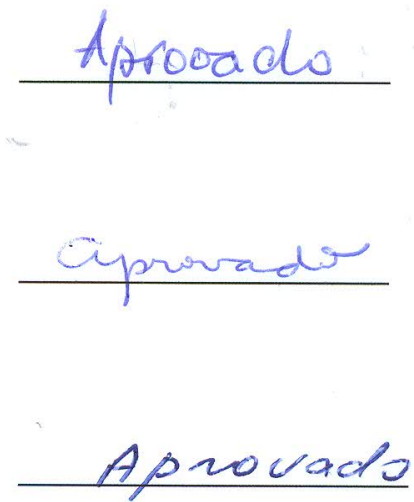

Coordenadora do Programa de Pós-Graduação em Engenharia Hidráulica e Saneamento:

Profa. Associada Maria Bernadete A. Varesche Silva

Presidente da Comissão de Pós-Graduação:

Prof. Titular Denis Vinicius Coury 

Dedico este trabalho à minha amada família, em especial à minha esposa Audrey, ao meu filho Luca Yugo, ao meu filho ou filha que já está a caminho e aos meus pais Moacir e Noemia. 

Um dia discursa a outro dia, e uma noite mostra sabedoria a outra noite.

Não há linguagem, nem há palavras, e deles não se houve nenhum som;

No entanto, por toda a terra se faz ouvir a sua voz, e as suas palavras até aos confins do mundo...

... A lei do Senhor é perfeita e restaura a alma; o testemunho do Senhor é fiel, e dá sabedoria aos simplices...

... Que as palavras dos meus lábios e o meditar do meu coração sejam agradáveis na tua presença, Senhor, rocha minha e redentor meu! 



\section{Agradecimentos}

Agradeço a Deus, por estar acima e no controle de tudo, por todo o amor e graça concedidos às pessoas que amo, por guiar os meus passos e aplainar os meus caminhos.

Aos amores da minha vida, minha esposa Audrey, meu filho Luca Yugo e ao meu filho ou filha que já está a caminho, por me fazerem ter a absoluta certeza de que tudo está sob a maravilhosa Graça de Deus. Amo vocês de todo o meu entendimento, de todo o meu coração e de toda a minha alma.

Aos meus pais, Moacir e Noemia, por me ensinarem a ser sempre um homem melhor, honrado, digno e fiel.

Aos meus irmãos, Moacir Jr. e Philippe, meus companheiros e protetores, com quem tenho a honra de compartilhar minha história.

Ao meu compadre Luis Barrales e à minha comadre Lauren Hikage, pelo constante carinho e exemplo, nos ajudando a forjar o caráter do Luca Yugo.

À toda minha família pelo amor, dedicação e compreensão durante toda minha vida. Em especial aos avós Silvana Lopes, Nelton Lopes (in memoriam), Rosalina Roberto de Araujo (in memoriam) e José Messias de Araujo (in memoriam).

Ao professor Eugenio Foresti pela cordialidade, compreensão e gentileza de todos os dias, pela excelente companhia e pelo excelente auxílio, mesmo sabendo de minhas limitações.

Aos grandes amigos: Felipe Scanavini, José Luiz Scanavini, Luiz Fernando Bezerra, Amanda Cavalheiro, Daniel Scribano, Yugo Matsuda, Lucas Hikage, André Turini, Rafael Esposito, Bruno Callado, Vitor Scaranello, Welldemberg Hubner, Felipe Silva, Aristides Barcellos, Henrique Ferraz e Heber Yamamoto pelo exemplo, companheirismo e por comporem meu caráter.

Aos amigos de BioProj: Paulo Gonçalves, Henrique Sonobe, Henrique Altero, Bruno Gaudencio, Stephanie Graciano, Margareth Sant'Anna e Nadir Guimarães pela 
colaboração durante todo o projeto de pesquisa. Em especial ao amigo Alessandro Daré pela dedicação dispensada, sem a qual não seria possível a conclusão deste trabalho.

Aos amigos de Águas de Niterói: Márcia Freiberg, André Malhando, André Pinheiro e Rodrigo Pereira pela fundamental colaboração durante toda a fase experimental.

À professora Marcia Damianovic e ao Dr. Tiago Martins pelas sugestões e avaliação do Plano de Qualificação.

À Águas do Brasil, na pessoa do Sr. Dr. André Lermontov, por fomentar e alicerçar de modo ímpar o desenvolvimento desta pesquisa.

Aos diretores executivos da Concessionária Águas de Niterói, Sr. Dante Luis Luvisotto (in memoriam) e Sr. Nelson Gomes, por acreditarem e confiarem na viabilidade desta pesquisa. 


\section{RESUMO}

ARAUJO, T.L.S. (2014). Desempenho de reator anaeróbio híbrido (leito fixo e manta de lodo) tratando esgoto sanitário em escala piloto. São Carlos, 2014. 101p. Dissertação (Mestrado) - Escola de Engenharia de São Carlos, Universidade de São Paulo.

O presente trabalho estudou o aumento de capacidade de tratamento de um reator UASB (Upflow Anaerobic Sludge Blanket) por meio da adição de material suporte para adesão celular (Biobob®), avaliando-se as eficiências de remoção de matéria orgânica (expressa como DQO - demanda química de oxigênio) e sólidos em suspensão (expressos como SST - sólidos em suspensão totais). O reator híbrido, no qual a biomassa está presente em suspensão e imobilizada no material suporte, foi submetido a baixos tempos de detenção hidráulica (TDH) e altas velocidades ascensionais $\left(\mathrm{v}_{\mathrm{s}}\right)$. A operação do reator anaeróbio, de volume útil igual a $12,5 \mathrm{~m}^{3}$, foi conduzida em duas etapas. Na primeira o sistema foi operado como um reator de manta de lodo e escoamento ascendente (UASB), com TDH de 8,8 h e velocidade ascensional de $0,63 \mathrm{~m} \cdot \mathrm{h}^{-1}$. Na segunda etapa, introduziuse 5,0 $\mathrm{m}^{3}$ de material suporte Biobob ${ }^{\circledR}$ no leito reacional do reator, transformando-o em reator anaeróbio híbrido (HAnR). Nessa condição, variou-se a vazão de alimentação, tendo o TDH variado entre 7,4 h ( $\mathrm{v}_{\mathrm{s}}$ de $\left.0,66 \mathrm{~m} \cdot \mathrm{h}^{-1}\right)$ a $3,9 \mathrm{~h}\left(\mathrm{v}_{\mathrm{s}}\right.$ de $\left.1,25 \mathrm{~m} \cdot \mathrm{h}^{-1}\right)$. Para ambas as etapas o sistema foi alimentado com esgoto sanitário à temperatura ambiente, após tratamento preliminar (gradeamento e caixa de areia). Para condições de operação similares, o reator anaeróbio híbrido (HAnR) apresentou melhor desempenho na remoção de DQO e SST que o reator UASB, acrescendo em até $18 \%$ e $30 \%$ a eficiência de remoção, respectivamente. Para a velocidade ascensional de 1,25 $\pm 0,02 \mathrm{~m} . \mathrm{h}^{-1}$ e TDH de $3,9 \pm 0,1 \mathrm{~h}$, o HAnR apresentou concentrações médias no efluente tratado de $205 \pm 46 \mathrm{mg}$

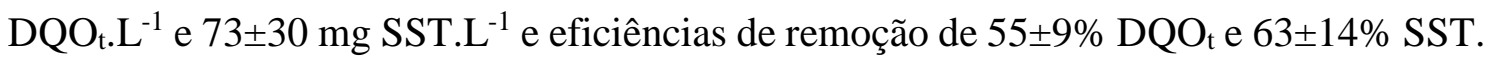

Palavras-chave: Reator UASB; reator híbrido; biomassa imobilizada; velocidade ascensional; esgoto sanitário. 


\section{Abstract}

ARAUJO, T.L.S. (2014). Performance of anaerobic hybrid reactor (fixed bed and sludge blanket) for sewage treatment in pilot scale. São Carlos, 2014. 101p. Master Degree Escola de Engenharia de São Carlos, Universidade de São Paulo.

The increase of the treatability capacity of a UASB (Upflow Anaerobic Sludge Blanket) reactor by introducing an innovative packing material (Biobobß) in its reaction zone was evaluated. The hybrid anaerobic reactor (HAnR) containing suspended and immobilized biomass was evaluated regarding its efficiency of removing organic matter (expressed as COD - chemical oxygen demand) and suspended solids (expressed as TSS - total suspended solids) under lower hydraulic detention time (HDT) and higher upflow velocities $\left(\mathrm{v}_{\mathrm{s}}\right)$. The anaerobic reactor operation, with $12.5 \mathrm{~m}^{3}$ of working volume, was conducted in two phases. In the first phase, the system was operated as a conventional UASB reactor with HRT of $8.8 \mathrm{~h}$ and $\mathrm{v}_{\mathrm{s}}$ of $0.63 \mathrm{~m} \cdot \mathrm{h}^{-1}$. In the second phase, $5.0 \mathrm{~m}^{3}$ of packing material Biobob® was introduced inside the reaction bed, changing the reactor configuration from suspended growth to hybrid growth. In this condition, the hybrid anaerobic reactor (HAnR) was subjected to decreasing flowrates with HDT ranging from $7.4 \mathrm{~h}\left(\mathrm{v}_{\mathrm{s}}\right.$ of $\left.0.66 \mathrm{~m} \cdot \mathrm{h}^{-1}\right)$ to $3.9 \mathrm{~h}\left(\mathrm{v}_{\mathrm{s}}\right.$ of $\left.1.25 \mathrm{~m} \cdot \mathrm{h}^{-1}\right)$. For both phases, the feed was domestic wastewater (after screens and grit chambers) at ambient temperature. Under similar operation conditions, the HAnR performed better than the UASB reactor increasing at $18 \%$ and $30 \%$ the COD and TSS removal efficiencies, respectively. For $\mathrm{v}_{\mathrm{s}}$ of $1.25 \pm 0.02$ $\mathrm{m} . \mathrm{h}^{-1}$ and HDT of $3.9 \pm 1.0 \mathrm{~h}$, the HAnR produced a very high quality effluent, with

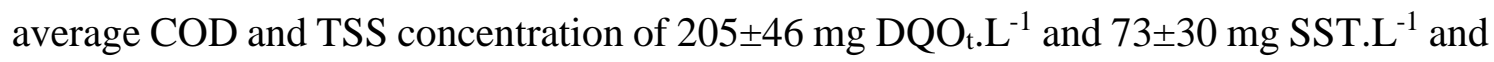
removal efficiencies of $55 \pm 9 \%$ and $63 \pm 14 \%$ for $\mathrm{COD}_{\mathrm{t}}$ and SST, respectively.

Key words: UASB reactor; hybrid reactor; biofilm reactor; upflow velocity; domestic wastewater. 


\section{Lista de Abreviaturas e Siglas}

\begin{tabular}{|c|c|}
\hline $\mathrm{AB}$ & Alcalinidade a bicarbonato \\
\hline $\mathrm{AF}$ & Anaerobic filter \\
\hline AAFEB & Anaerobic attached film expanded bed \\
\hline AnMBR & Anaerobic membrane bioreactor \\
\hline AnSBR & Anaerobic sequential bath reactor \\
\hline AVT & Ácidos voláteis totais \\
\hline $\mathrm{BRN}$ & Bactérias redutoras de nitrogênio \\
\hline BRS & Bactérias redutoras de sulfato \\
\hline$-\mathrm{COOH}$ & Radical carboxila \\
\hline $\mathrm{CaCO}_{3}$ & Carbonato de cálcio, $[\mathrm{M}] .\left[\mathrm{L}^{-3}\right]$ \\
\hline $\mathrm{CO}_{2}$ & Gás carbônico \\
\hline $\mathrm{CH}_{4}$ & Gás metano \\
\hline $\mathrm{CH}_{3} \mathrm{COO}^{-}$ & Íon acetato \\
\hline $\mathrm{CH}_{3} \mathrm{COOH}$ & Ácido acético \\
\hline $\mathrm{CH}_{3} \mathrm{CH}_{2} \mathrm{COOH}$ & Ácido propiônico \\
\hline $\mathrm{CH}_{3} \mathrm{CH}_{2} \mathrm{CH}_{2} \mathrm{COOH}$ & Ácido butírico \\
\hline $\mathrm{CH}_{3} \mathrm{CH}(\mathrm{OH}) \mathrm{COOH}$ & Ácido lactico \\
\hline $\mathrm{CHV}$ & Carga hidráulica volumétrica \\
\hline CNTP & Condições normais de temperatura e pressão \\
\hline $\mathrm{COV}$ & Carga orgânica volumétrica \\
\hline DBO & Demanda bioquímica de oxigênio \\
\hline DNA & Ácido desoxirribonucleico \\
\hline $\mathrm{DQO}_{\mathrm{t}}$ & Demanda química de oxigênio total \\
\hline $\mathrm{DQO}_{\mathrm{f}}$ & Demanda química de oxigênio filtrada \\
\hline $\mathrm{E}_{\mathrm{DQO}}$ & Eficiência na remoção de $\mathrm{DQO}_{\mathrm{t}}$ \\
\hline
\end{tabular}


EGSB

EPS

ESST

ETE

FB

$\mathrm{Fe}^{3+}$

HAc

$\mathrm{HBu}$

$\mathrm{HCO}_{3}{ }^{-}$

HAnR

HPr

$\mathrm{H}_{2}$

$\mathrm{H}_{2} \mathrm{~S}$

i

IBGE

IC

$\mathrm{MM}_{\mathrm{CH} 4}$

$\mathrm{Mn}^{4+}$

$\mathrm{N}$

$\mathrm{N}$-amoniacal

$\mathrm{Na}_{2} \mathrm{~S}$

$\mathrm{NaHCO}_{3}$

$\mathrm{NaOH}$

NMP

$-\mathrm{NH}_{2}$

$\mathrm{N}-\mathrm{NH}_{3}$

$\mathrm{N}-\mathrm{NH}_{4}{ }^{+}$

$\mathrm{N}-\mathrm{NO}_{2}{ }^{-}$

$\mathrm{N}-\mathrm{NO}_{3}{ }^{-}$

$\mathrm{N}$-org

NT

NTK

$-\mathrm{OH}$

$\mathrm{O}_{2}$
Expanded granular sludge bed

Extracellular Polymeric Substances

Eficiência na remoção de SST

Estação de tratamento de esgoto

Fixed film fluidized bed

Íon ferro (III)

Ácido acético, $[\mathrm{M}] .\left[\mathrm{L}^{-3}\right]$

Ácido butírico, $[\mathrm{M}] .\left[\mathrm{L}^{-3}\right]$

Bicarbonato

Hybrid anaerobic reactor

Ácido propiônico, $[\mathrm{M}] .\left[\mathrm{L}^{-3}\right]$

Gás hidrogênio

Gás sulfídrico

Dia operacional [T]

Instituto brasileiro de geografia e estatística

Internal circulation

Massa molecular do metano, $[\mathrm{M}] .\left[\mathrm{M}^{-1}\right]$

Íon manganês

Elemento químico nitrogênio

Nitrogênio na forma amoniacal $\left(\mathrm{N}-\mathrm{NH}_{4}{ }^{+}+\mathrm{N}-\mathrm{NH}_{3}\right)$

Sulfeto de sódio

Bicarbonato de sódio

Hidróxido de sódio

Número mais provável

Radical amina

Nitrogênio na forma de gás amônia

Nitrogênio na forma de íon amônio

Nitrogênio na forma de nitrito (N-nitrito)

Nitrogênio na forma de nitrato (N-nitrato)

Nitrogênio na forma orgânica

Nitrogênio total $\left(\mathrm{NTK}+\mathrm{N}-\mathrm{NO}_{2}{ }^{-}+\mathrm{N}-\mathrm{NO}_{3}{ }^{-}\right)$

Nitrogênio total Kjeldahl

Radical hidroxila

Oxigênio molecular 
P

P_CH4,atm

$\mathrm{P}_{\mathrm{CH} 4}$

$\mathrm{P}_{\text {Lodo }}$

$\mathrm{pH}$

$\mathrm{pKa}$

PRFV

PSD

PU

PVC

Q

R

RAHLF

RNA

S

$\mathrm{S}_{0}$

$\mathrm{S}^{0}$

$\mathrm{SO}_{3}{ }^{2-}$

$\mathrm{SO}_{4}^{2-}$

SST

SSV

ST

SVT

$\mathrm{T}$

TDH

UASB

$\mathrm{V}_{\mathrm{CH} 4}$

$\mathrm{V}_{\mathrm{d}}$

$\mathrm{v}_{\mathrm{S}}$

$X_{d}$

$X_{\mathrm{e}}$

Y

$\mathrm{Y}_{\mathrm{obs}}$
Elemento químico fósforo

Pressão do metano quando liberado para a atmosfera, $[\mathrm{M}] .\left[\mathrm{L}^{-2}\right]$

Rendimento da produção de metano, $[\mathrm{M}] .\left[\mathrm{M}^{-1}\right]$

Produção de lodo, [M].[M-1 $]$

Potencial hidrogeniônico

Constante de dissociação ácida

Plástico reforçado com fibra de vidro

Particle size distribution

Poliuretano

Policloreto de vinila

Vazão afluente

Constante universal dos gases ideais, $[\mathrm{M}] \cdot\left[\mathrm{L}^{3}\right] .\left[\mathrm{L}^{-2}\right] .\left[\mathrm{M}^{-1}\right] .\left[\mathrm{T}^{-1}\right]$

Reator anaeróbio horizontal de leito fixo

Ácido ribonucleico

Concentração de substrato no efluente, $[\mathrm{M}] .\left[\mathrm{L}^{-3}\right]$

Concentração do substrato no afluente, $[\mathrm{M}] \cdot\left[\mathrm{L}^{-3}\right]$

Enxofre elementar

Íon sulfito

Íon sulfato

Sólidos em suspensão totais

Sólidos em suspensão voláteis

Sólidos totais

Sólidos voláteis totais

Temperatura

Tempo de detenção hidráulica

Upflow anaerobic sludge blanket

Volume de metano produzido, $\left[\mathrm{L}^{3}\right]$

Volume de lodo descartado do reator, [ $\left.\mathrm{L}^{3}\right]$

Velocidade ascensional, [L].[T $\left.\mathrm{T}^{-1}\right]$

Concentração de biomassa do lodo descartado, $[\mathrm{M}] .\left[\mathrm{L}^{-3}\right]$

Concentração de biomassa no efluente, $[\mathrm{M}] \cdot\left[\mathrm{L}^{-3}\right]$

Coeficiente de produção celular, $[\mathrm{M}] .\left[\mathrm{M}^{-1}\right]$

Coeficiente de produção de sólidos observado, $[\mathrm{M}] .\left[\mathrm{M}^{-1}\right]$ 


\section{LiSTA DE Figuras}

Figura 3.1 - Rotas metabólicas e grupos microbianos envolvidos na digestão anaeróbia (Adaptado de: LETTINGA et al., 1996).

Figura 3.2 - Classificação usual para sistemas anaeróbios de alta taxa tratando esgotos sanitários.

Figura 3.3 - Conversão biológica em processos aeróbios e anaeróbios (Adaptado de: LETTINGA, 1997).

Figura 3.4 - Conversão biológica em processos aeróbios e anaeróbios (Adaptado de: CHERNICHARO, 2007).

Figura 3.5 - Esquema representativo do reator UASB.

Figura 3.6 - Esquema de hipótese de interação para a remoção física de sólidos em suspensão em reator UASB (Fonte: Adaptado de MAHMOUD et al., 2003).

Figura 3.7 - Esquema representativo do filtro anaeróbio de fluxo ascendente. 29

Figura 3.8 - Esquema representativo do filtro anaeróbio de fluxo descendente. 29

Figura 3.9 - Esquema representativo do reator anaeróbio híbrido. 33

Figura 4.1 - Foto aérea da ETE Itaipu, Niterói, RJ: (1) tratamento preliminar;

(2) reator UASB; (3) reator anóxico; (4) reatores aeróbios com biodisco; (5) decantador secundário; (6) decantador terciário; e (7) laboratório (Fonte: Google Earth, 2011).

Figura 4.2 - Fluxograma simplificado da ETE Itaipu, Niterói, RJ.

Figura 4.3 - Fotos da instalação experimental: (a) vista frontal; e (b) vista oposta: (1) reator anaeróbio, (2) selo hídrico, (3) medidor de biogás, (4) reator anóxico, (5) reator aeróbio, (6) soprador de ar, (7) bomba de recirculação (aeróbio-anóxico), (8) decantador secundário, (9) bomba de recirculação e descarte de lodo e (10) painel elétrico.

Figura 4.4 - Fluxograma de processo do reator anaeróbio piloto.

Figura 4.5 - Fotos da fabricação e montagem do reator piloto: (a) fabricação das estruturas de sustentação do leito, defletor e calha de saída; (b) instalação do separador trifásico; (c) instalação da tela de sustentação do leito; (d) montagem do ramal de alimentação; (e) bomba de alimentação e cesto de proteção; (f) medidor de biogás; (g) instalação e montagem eletromecânica concluídas; e (h) reator piloto em operação.

Figura 4.6 - Desenho dimensional do reator anaeróbio (medidas em milímetros): (a) vista longitudinal (Corte AA) e (b) vista em planta. 
Figura 4.7 - Fotos do material suporte Biobob®: (a) sem biomassa e (b) com biomassa aderida.

45

52

54

Figura 5.2 - Gráfico Box-plot de distribuição dos resultados de $\mathrm{DQO}_{\mathrm{t}}$ afluente e efluente para cada TDH aplicado ao longo da operação do reator anaeróbio.

Figura 5.3 - Gráfico Box-plot de distribuição dos resultados de $\mathrm{DQO}_{\mathrm{f}}$ afluente e efluente para cada TDH aplicado ao longo da operação do reator anaeróbio.

Figura 5.4 - Valores de SST afluente e efluente ao longo da operação do reator anaeróbio.

Figura 5.5 - Gráfico Box-plot de distribuição dos resultados de SST afluente e efluente para cada TDH aplicado ao longo da operação do reator anaeróbio.

Figura 5.6 - Eficiência de remoção de $\mathrm{DQO}_{\mathrm{t}}$ em função da carga hidráulica volumétrica e TDH aplicados ao reator anaeróbio.

Figura 5.7 - Eficiência de remoção de SST em função da carga hidráulica volumétrica e TDH aplicados ao reator anaeróbio.

Figura 5.8 - Eficiência de remoção de $\mathrm{DQO}_{t}$ em função da carga orgânica volumétrica aplicada.

Figura 5.9 - Eficiência de remoção de $\mathrm{DQO}_{t}$ em função do tempo de detenção hidráulica.

Figura 5.10 - Valores médios de $\mathrm{DQO}_{\mathrm{t}}$ no efluente em função do tempo de detenção hidráulica.

Figura 5.11 - Eficiência de remoção de SST em função da velocidade ascensional aplicada.

Figura 5.12 - Eficiência de remoção de SST em função do tempo de detenção hidráulico.

Figura 5.13 - Valores médios de SST no efluente em função do tempo de detenção hidráulica.

Figura 5.14 - Valores da produção de metano e temperatura do esgoto sanitário afluente ao longo da operação do reator anaeróbio.

Figura 5.15 - Valores de pH do selo hídrico ao longo da operação do reator anaeróbio.

Figura 5.16 - Gráfico Box-plot de distribuição dos resultados de rendimento da produção de metano ao longo da operação do reator anaeróbio.

Figura 5.17 - Valores de AVT afluente e efluente ao longo da operação do reator anaeróbio.

Figura 5.18 - Valores de $A B$ afluente e efluente ao longo da operação do reator anaeróbio.

Figura 5.19 - Perfil de $\mathrm{pH}$ afluente e efluente ao longo da operação do reator anaeróbio.

Figura 5.20 - Perfil de nitrogênio total e amoniacal no afluente e efluente ao longo da operação do reator anaeróbio.

Figura 5.21 - Fotos do afluente e efluente do HAnR (Etapa 2).

Figura 5.22 - Fotos das amostras de Biobob® coletadas do leito fixo do HAnR. 


\section{LiSTA DE TABELAS}

Tabela 4.1 - Características do suporte utilizado para imobilização da biomassa.

Tabela 4.2 - Composição média do esgoto sanitário estudado. 46

Tabela 4.3 - Variáveis analisadas, métodos utilizados e frequência de amostragem durante a operação do reator UASB.

Tabela 4.4 - Resumo das etapas experimentais do reator anaeróbio.

Tabela 5.1 - Resultados médios de DQO e SST afluente e efluente, eficiência de remoção de DQO e SST em função do tempo de detenção hidráulico $(\mathrm{TDH})$, da velocidade ascensional aparente $\left(\mathrm{v}_{\mathrm{s}}\right)$ e da carga orgânica volumétrica (COV) aplicados.

Tabela 5.2 - Parâmetros operacionais e desempenho de sistemas anaeróbios tratando esgotos sanitários.

Tabela 5.3 - Os valores médios da produção de metano na CNTP, do volume de biogás e temperatura do esgoto sanitário afluente para cada TDH e COV.

Tabela 5.4 - Resultados médios dos parâmetros analisados durante a operação do reator anaeróbio.

Tabela 5.5 - Quantificação da biomassa aderida no material suporte.

Tabela 5.6 - Balanço de massa da produção de biomassa no HAnR durante o período operacional. 



\section{SUMÁRIO}

RESUMO i i

ABSTRACT

LISTA DE ABREVIATURAS E SIGLAS iii

LISTA DE FIGURAS vi

LISTA DE TABELAS viii

1 INTRODUÇÃO

2 OBJETIVOS 4

2.1 Objetivo geral 4

2.2 Objetivos específicos

3 REVISÃO BIBLIOGRÁFICA 5

3.1 Digestão anaeróbia

3.1.1 Hidrólise e acidogênese $\quad 7$

3.1.2 Acetogênese 8

3.1.3 Metanogênese $\quad 8$

3.1.4 Sulfeogênese 9

3.2 Reatores anaeróbios tratando esgotos sanitários 11

3.2.1 Reator anaeróbio de manta de lodo e escoamento ascendente $\quad 16$

3.2.1.1 Influência da característica dos esgotos sanitários bruto 20

3.2.1.2 Influência das condições operacionais 23

3.2.1.3 Influência da característica do lodo desenvolvido 25

3.2.2 Reator anaeróbio de leito fixo 28

3.2.3 Reator anaeróbio híbrido $\quad 32$

3.3 Biomassa imobilizada em suporte inerte $\quad 34$

3.4 Considerações finais $\quad 35$

4 MATERIAL E MÉTODOS 37

4.1 Descrição geral dos experimentos 37

4.2 Reator em escala piloto 38

4.3 Suportes para imobilização da biomassa $\quad 45$ 
4.4 Água residuária $\quad 46$

4.5 Inóculo 46

$\begin{array}{ll}\text { 4.6 Análises físico-químicas } & 47\end{array}$

4.6.1 Quantificação da biomassa aderida nos suportes 48

4.7 Cálculo do rendimento e da produção de sólidos ( $\mathbf{Y}_{\text {obs; }}$ P $\left.\mathbf{P}_{\text {Lodo }}\right)$

4.8 Cálculo do rendimento da produção metano 49

4.9 Procedimento experimental $\quad 50$

4.9.1 Etapa 1 - Reator UASB $\quad 50$

4.9.2 Etapas 2 a 9 - Reator anaeróbio híbrido (leito fixo e manta de lodo)

4.9.3 Resumo das etapas experimentais $\quad 54$

5 RESULTADOS E DISCUSSÃO 57

$\begin{array}{ll}5.1 \text { Operação do reator anaeróbio } & 57\end{array}$

$\begin{array}{ll}\text { 5.2 Quantificação da biomassa aderida nos suportes } & 78\end{array}$

5.3 Rendimento e produção de sólidos (Y Yobs; PLodo) 79

6 CONCLUSÕES

7 SUGESTÕES

8 REFERÊNCIAS BIBLIOGRÁFICAS 85 



\section{INTRODução}

O tratamento de esgotos sanitários representa um grande desafio atualmente, visto que o crescimento populacional intenso, notadamente em países em desenvolvimento, como o Brasil, não é acompanhado pelas obras de infraestrutura e medidas estruturantes (especificações, etc.) necessárias, em especial as de saneamento. Como consequência, estabelece-se uma situação de precariedade em relação à saúde da população e à conservação ambiental. No Brasil, a Pesquisa Nacional de Saneamento Básico de 2008 mostrou que somente $55,2 \%$ dos municípios brasileiros possuem rede coletora de esgotos sanitários, e apenas $28,5 \%$ realizam algum tipo de tratamento dos esgotos coletado (IBGE, 2010). Desta forma, é de extrema importância o desenvolvimento de tecnologias eficientes e econômicas que viabilizem a aplicação de sistemas de tratamento de forma ampla e satisfatória para a melhoria das condições de saneamento.

A aplicação de reatores anaeróbios como unidades principais de tratamento tem se mostrado economicamente vantajosa para a remoção de matéria orgânica de esgoto sanitário, principalmente em regiões tropicais e subtropicais onde a temperatura ambiente favorece a digestão anaeróbia. O desenvolvimento de reatores anaeróbios de alta taxa, operados com alto tempo de retenção celular e baixo tempo de detenção hidráulica incorporando altas quantidades de biomassa ativa, proporcionam um alto potencial para o tratamento de águas residuárias com baixas concentrações de substrato, como o esgoto sanitário (LETTINGA, 2001). Entretanto, dificilmente esses reatores produzem efluentes que atendem aos padrões estabelecidos pela legislação ambiental brasileira, além de terem pouco efeito sobre os macronutrientes ( $\mathrm{N}$ e $\mathrm{P}$ ). Deste modo, a adoção de unidades de póstratamento de seus efluentes faz-se necessária, visto que os sistemas anaeróbios mais comumente aplicados, como os reatores UASB - Upflow Anaerobic Sludge Blanket, não são capazes de remover de modo satisfatório estes compostos (CHERNICHARO, 2001). 
Entre as opções de tratamento de esgotos sanitários, os sistemas combinados anaeróbio-aeróbio mostram-se promissores, principalmente quando, além da redução da matéria orgânica, deseja-se a remoção de nutrientes, em particular do nitrogênio orgânico e amoniacal. Entre as vantagens dos sistemas combinados anaeróbio-aeróbio destacamse a baixa potência de aeração requerida na fase aeróbia, menor produção de lodo biológico e baixo custo de implantação e operação, quando comparados aos sistemas convencionais por lodos ativados (KASSAB et al., 2010).

Neste contexto, grande parte das estações de tratamento de esgotos sanitários implantadas no Brasil foram projetadas utilizando, de forma combinada, reatores anaeróbios (UASB) e aeróbios (Lodos Ativados) para a remoção da matéria orgânica e do nitrogênio orgânico e amoniacal.

Contudo, com o intenso crescimento populacional e o consequente aumento da vazão afluente de esgotos nestas estações, a concepção original dos reatores UASB apresenta dificuldades para tratar efluentes com elevadas cargas volumétricas e concentrações de sólidos, como os esgotos sanitários, onde a velocidade ascensional e a digestão da DQO particulada são as etapas limitantes do processo (LETTINGA \& HULSHOFF POL, 1991; FORESTI et al., 2006; van HAANDEL et al., 2006).

O bom contato entre a biomassa e o substrato são fundamentais para garantir uma boa velocidade de degradação. Com mistura insuficiente, devido à baixa velocidade ascensional aplicada e à baixa produção de biogás, os reatores UASB apresentam limitações de transferência de massa, além de um maior potencial de formação de escuma.

Deste modo, os reatores UASB foram desenvolvidos para tratar efluentes cuja concentração favoreça a mistura e a ocorrência da granulação do lodo promovidas pelos gases, e não pelo fluxo do líquido (KATO et al., 1999). Segundo Foresti et al. (2006), apesar do reconhecido sucesso dos reatores UASB para o tratamento de esgotos sanitários, a perda de sólidos no efluente e a formação de escuma no interior do separador trifásico são duas limitações evidentes.

Assim, o maior sucesso dos reatores UASB de fato não se deu para o tratamento de esgotos sanitários, e seu desempenho pode ser melhorado se pesquisas forem desenvolvidas no sentido de adaptar seu desenho às características desta água residuária (FORESTI et al., 2006).

Sob o prisma da gestão e sustentabilidade socioeconômica, grande parte das estações de tratamento de esgotos sanitários em operação no Brasil enfrenta dois fatores principais: (i) o gerenciamento e a disposição do lodo biológico e da escuma gerados; e 
(ii) a necessidade de se aumentar a capacidade de tratamento para acompanhar o crescimento populacional.

Estes fatores refletem diretamente nos custos operacionais das estações de tratamento, influenciando nas decisões de implantação e gestão das mesmas. Neste sentido, alternativas tecnológicas que possibilitem o aumento de capacidade de tratamento destas estações, conjuntamente com a redução da geração de lodo biológico são de extrema relevância para o setor.

Uma das alternativas é o aumento da concentração inicial de biomassa no sistema, fazendo com que o substrato seja o fator limitante nos processos de produção e manutenção celular. Essa condição pode ser alcançada por meio de reatores de leito fixo, nos quais observa-se um crescimento regulado da biomassa (ZAIAT et al., 1994). Com a utilização de biomassa imobilizada nos reatores biológicos, pode-se aumentar consideravelmente a massa de microrganismos contida nestes reatores, aumentando consequentemente a capacidade nominal de tratamento dos mesmos.

As características do material suporte para a adesão celular (geometria, dimensões, material, porosidade, etc.) exercem uma grande influência no desempenho de reatores de leito fixo. Atualmente, diversos tipos de materiais suporte com altas áreas superficiais foram desenvolvidos. No entanto, grande parte destes não são capazes de proporcionar simultaneamente uma alta porosidade do leito reacional (evitando o cúmulo excessivo de biomassa e consequente aumento da perda de carga) e uma alta capacidade de adesão da biomassa. Assim, frequentes contra lavagens são requeridas para remover o excesso de biofilme formado e reestabelecer o bom desempenho dos reatores biológicos (KASSAB et al., 2010).

Estudos anteriores demonstraram que a espuma de poliuretano (PU) é um excelente suporte para a adesão de biomassa (HUYSMAN et al., 1983; ARAUJO JR \& ZAIAT, 2009; GUO et al., 2010; LIM et al., 2011). No entanto, sua alta compressibilidade e baixa resistência mecânica têm limitado seu uso em plantas em escala comercial. A fim de resolver este problema, um inovador suporte chamado Biobob® (matriz de espuma de PU envolto por uma estrutura externa rígida de polipropileno) foi desenvolvido.

Assim, o presente trabalho objetivou estudar o aumento de capacidade de tratamento de um reator UASB por meio da adição de material suporte para adesão de biomassa (Biobob®), operando como reator anaeróbio híbrido (presença de biomassa suspensa e biomassa aderida), visando a remoção de matéria orgânica e de sólidos em suspensão, submetido a altas cargas volumétricas e altas velocidades ascensionais. 


\section{2 Ов:ЕтTos}

\subsection{OBJETIVO GERAL}

O objetivo principal do projeto de pesquisa foi avaliar o desempenho de um reator anaeróbio híbrido (leito fixo e manta de lodo), em escala piloto, contendo material suporte para imobilização celular (Biobob®) tratando altas cargas volumétricas de esgoto sanitário.

\subsection{OBJETIVOS ESPECÍFICOS}

Os objetivos específicos do projeto de pesquisa foram:

- Comparar o desempenho do sistema operando na sua configuração tradicional (como reator anaeróbio de manta de lodo e escoamento ascendente - UASB) e como reator anaeróbio híbrido (leito fixo e manta de lodo);

- Avaliar a influência do tempo de detenção hidráulica no desempenho do reator anaeróbio híbrido quanto à remoção de matéria orgânica;

- Avaliar a influência da velocidade ascensional (acima de 1,00 m.h $\mathrm{h}^{-1}$ ) no desempenho do reator anaeróbio híbrido quanto à retenção de sólidos em suspensão;

- Quantificar e comparar com resultados apresentados na literatura a produção de sólidos do sistema operando como reator anaeróbio híbrido. 


\section{Revisão Bibliográfica}

\subsection{DIGESTÃo ANAERÓBIA}

A digestão anaeróbia é um processo biológico natural e autorregulado por meio do qual diferentes populações microbianas cooperam no processo de decomposição da matéria orgânica para formar metano e gás carbônico como principais produtos finais (MOSEY, 1983).

Em condições de anaerobiose, aceptores de elétrons inorgânicos como o sulfato $\left(\mathrm{SO}_{4}{ }^{2-}\right)$ ou dióxido de carbono $\left(\mathrm{CO}_{2}\right)$ são utilizados no processo de oxidação da matéria orgânica. A formação de metano $\left(\mathrm{CH}_{4}\right)$ não ocorre em meios onde o oxigênio molecular $\left(\mathrm{O}_{2}\right)$, nitratos $\left(\mathrm{NO}_{3}{ }^{-}\right)$, sulfatos $\left(\mathrm{SO}_{4}{ }^{2-}\right)$, enxofre $\left(\mathrm{S}^{0}\right)$ ou íons metálicos oxidados $\left(\mathrm{Fe}^{3+}\right.$; $\mathrm{Mn}^{4+}$ ) encontram-se prontamente disponíveis como aceptores de elétrons, ou seja, apenas os processos de fermentação e de respiração com prótons ou bicarbonato $\left(\mathrm{HCO}_{3}{ }^{-}\right)$como aceptor de elétrons são possíveis (STAMS, 1994).

Neste contexto, Harper e Pohland (1986) descrevem a digestão anaeróbia como um processo ecológico equilibrado e preciso, onde diferentes populações de microrganismos apresentam funções especializadas e a degradação de compostos orgânicos é usualmente considerada um processo de dois estágios. No primeiro estágio, um grupo de bactérias facultativas e anaeróbias convertem (por hidrólise e fermentação) os compostos orgânicos complexos (carboidratos, proteínas e lipídios) em compostos orgânicos simples, principalmente em ácidos orgânicos, bem como em dióxido de carbono e gás hidrogênio $\left(\mathrm{H}_{2}\right)$.

No segundo estágio, os ácidos orgânicos e o hidrogênio são convertidos em metano e dióxido de carbono. Esta conversão, chamada metanogênese, ocorre por meio de um grupo especial de microrganismos, os quais são estritamente procariontes (WOESE 
et al., 1977). As arqueias metanogênicas acetoclásticas convertem o acetato $\left(\mathrm{CH}_{3} \mathrm{COO}^{-}\right)$ a metano e as arqueias metanogênicas hidrogenotróficas produzem o metano a partir do dióxido de carbono e do hidrogênio. As arqueias metanogênicas dependem portanto do substrato produzido pelos microrganismos formadores de ácidos, consistindo por conseguinte, em uma relação sintrófica.

Aproximadamente $70 \%$ do metano produzido provêm da metanogênese acetoclástica; o restante resulta da conversão de hidrogênio e dióxido de carbono a metano (JERIS \& McCARTY, 1965; SMITH \& MAH, 1966). A produção de metano depende, portanto, da conversão eficiente de matéria orgânica em acetato na etapa prévia.

Os microrganismos acidogênicos e metanogênicos diferem significativamente em termos fisiológicos, necessidades nutricionais, cinética de crescimento e sensibilidade às condições ambientais. A conversão de ácidos orgânicos com mais de dois carbonos na cadeia só é termodinamicamente favorável se a pressão parcial de hidrogênio no meio é inferior a $10^{-4}$ atm (HARPER \& POHLAND, 1986), o que torna a eficiência e a estabilidade do processo dependentes da remoção de hidrogênio do meio, por meio do mecanismo denominado transferência de hidrogênio interespécies (THIELE et al., 1988). Em sistemas convencionais, as diferentes populações compartilham o mesmo reator e estão sujeitas às mesmas condições operacionais. Alterações nas condições operacionais resultantes, por exemplo, de sobrecargas orgânicas, de variações na composição da água residuária, entre outros fatores, podem levar ao desequilíbrio entre as etapas acidogênica e metanogênica e diminuição significativa de desempenho do reator.

Embora a digestão anaeróbia seja usualmente considerada um processo de dois estágios, ela pode ser subdividida em várias rotas metabólicas, com a participação de diversos grupos de microrganismos com diferentes fisiologias, como apresentado na Figura 3.1 e descrito nos itens a seguir. 


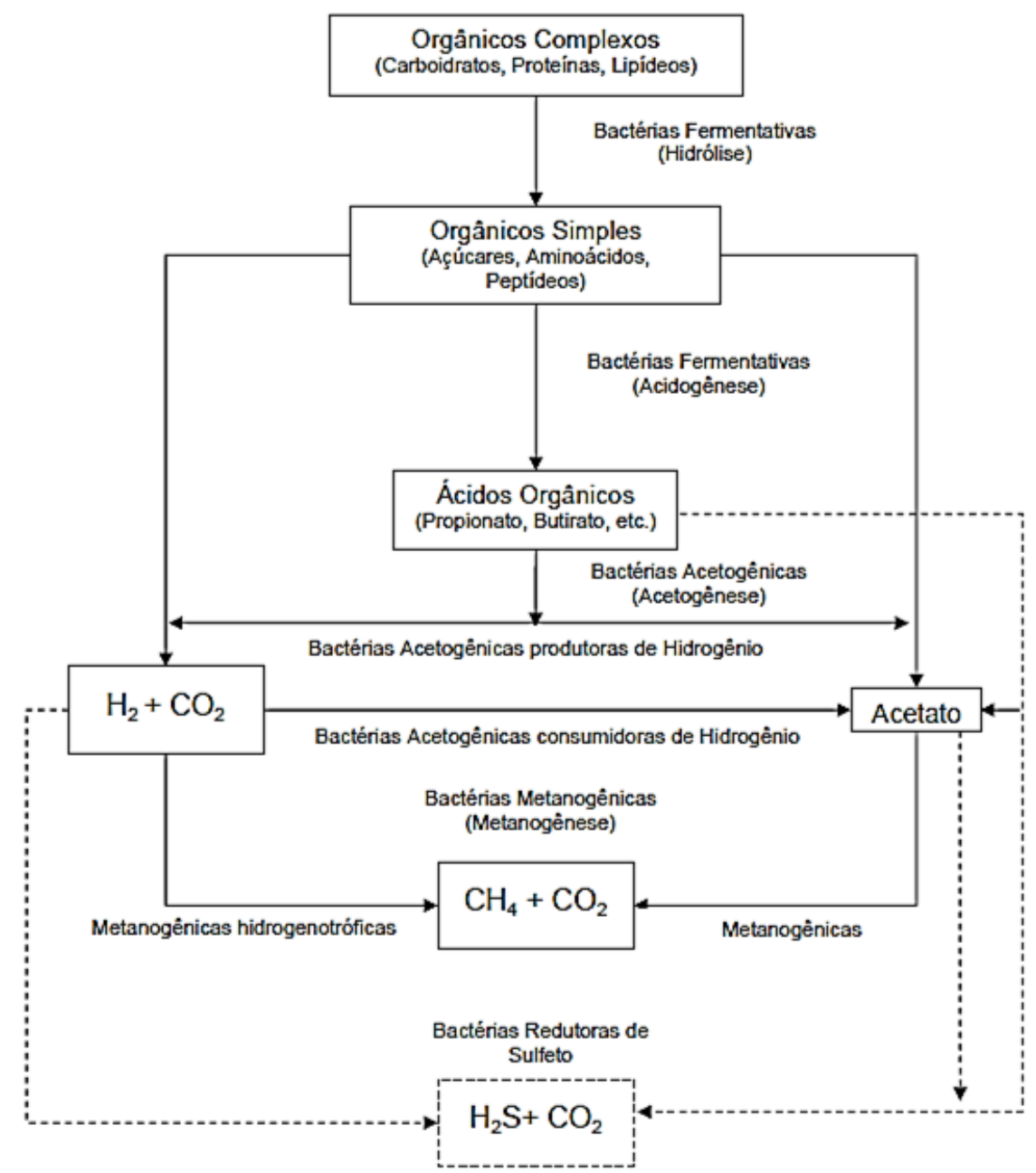

Figura 3.1 - Rotas metabólicas e grupos microbianos envolvidos na digestão anaeróbia (Adaptado de: LETTINGA et al., 1996).

\subsubsection{Hidrólise e Acidogenese}

A primeira etapa do processo de digestão anaeróbia consiste na hidrólise da matéria orgânica complexa insolúvel, tal como carboidratos, proteínas e lipídios, em substâncias menos complexas (açucares solúveis, aminoácidos e ácidos graxos), por meio da ação de exoenzimas, permitindo portanto, a penetração destas moléculas menores na membrana celular das bactérias fermentativas. A hidrólise de polímeros usualmente ocorre de modo lento em condições de anaerobiose e diversos fatores afetam o grau e a velocidade com que estes compostos são hidrolisados (LETTINGA et al., 1996).

Os produtos da hidrólise são metabolizados e convertidos dentro da célula das bactérias fermentativas acidogênicas em ácidos orgânicos, álcoois, ácido láctico $\left(\mathrm{CH}_{3} \mathrm{CH}(\mathrm{OH}) \mathrm{COOH}\right)$, hidrogênio, dióxido de carbono, amônia $\left(\mathrm{NH}_{3}\right)$ e sulfeto de hidrogênio $\left(\mathrm{H}_{2} \mathrm{~S}\right)$, que são posteriormente excretados para fora da célula. 


\subsubsection{Acetogênese}

Bactérias acetogênicas são responsáveis pela oxidação dos produtos formados na etapa acidogênica em substratos apropriados para os microrganismos metanogênicos (ácido acético, hidrogênio e dióxido de carbono).

Deste modo, as bactérias acetogênicas são integrantes de um grupo metabólico intermediário, o qual produz o substrato para os microrganismos metanogênicos.

Durante a formação dos ácidos acético $\left(\mathrm{CH}_{3} \mathrm{COOH}\right)$ e butírico $\left(\mathrm{CH}_{3} \mathrm{CH}_{2} \mathrm{CH}_{2} \mathrm{COOH}\right)$, uma grande quantidade de hidrogênio é formado, causando uma redução do $\mathrm{pH}$ do meio. Contudo, existem dois modos pelos quais o hidrogênio é consumido no meio: (i) por meio dos microrganismos metanogênicos, os quais utilizam o hidrogênio e o dióxido de carbono para produzir metano; e (ii) por meio da formação de ácidos orgânicos, como o ácido propriônico $\left(\mathrm{CH}_{3} \mathrm{CH}_{2} \mathrm{COOH}\right)$, o qual é formado por meio da reação entre o hidrogênio e ácido pirúvico (MOSEY, 1983).

Portanto, a fermentação acetogênica tem um papel importante na conversão de matéria orgânica em energia, na forma de metano, pois o acetato é o principal precursor do metano. Para que a produção de energia venha a ser economicamente viável, a conversão de substrato a acetato deve ser rápida (GHOSH \& LALL, 1981). Caso essa conversão não ocorra, haverá o acúmulo dos produtos da hidrólise e da fermentação ácida no reator, inibindo a metanogênese (FORESTI et al., 1999).

\subsubsection{Metanogênese}

A etapa final do processo global de degradação anaeróbia de compostos orgânicos em $\mathrm{CH}_{4} \mathrm{e} \mathrm{CO}_{2}$ é realizada pelas arqueas metanogênicas. Estes microrganismos, divididos em dois grupos principais: (i) formadores de metano a partir do ácido acético ou metanol; e (ii) formadores de metano a partir do hidrogênio e dióxido de carbono; utilizam um número limitado de substratos, compreendendo o ácido acético, o hidrogênio, o dióxido de carbono, ácido fórmico, metanol, metilamina e monóxido de carbono.

As arqueas metanogênicas acetoclásticas são responsáveis por $60 \%$ a $70 \%$ da produção total de metano na digestão anaeróbia, a partir do grupo metila do ácido acético (JERIS \& McCARTY, 1965). Embora uma pequena quantidade de espécies metanogênicas sejam capazes de formar metano a partir do acetato, normalmente estes 
microrganismos prevalecem na digestão anaeróbia.

Ao contrário dos organismos acetocálsticos, praticamente todas as espécies de metanogênicas conhecidas são capazes de produzir metano a partir do hidrogênio e dióxido de carbono.

Os microrganismos metanogênicos acetoclásticos e hidrogenotróficos são extremamente importantes na manutenção e equilíbrio da digestão anaeróbia, pois são responsáveis pelo consumo do hidrogênio formado nas etapas prévias. Consequentemente, a pressão parcial de hidrogênio no meio é reduzida, possibilitando assim as reações de produção das bactérias acidogênicas e acetogênicas.

\subsubsection{Sulfetogênese}

Em reatores tratando águas residuárias contendo sulfato ou sulfito $\left(\mathrm{SO}_{3}{ }^{2-}\right)$, as bactérias redutoras de sulfato (BRS) utilizam estes compostos como aceptores de elétrons durante a oxidação da matéria orgânica (LETTINGA et al., 1996).

O metabolismo das BRS é importante para o processo anaeróbio, principalmente devido ao seu produto, sulfeto de hidrogênio $\left(\mathrm{H}_{2} \mathrm{~S}\right)$. Espécies do grupo das BRS possuem em comum o metabolismo de dissimilação do sulfato sob condições estritas de anaerobiose e são consideradas um grupo versátil de microrganismos, capazes de utilizar uma ampla variedade de substratos, incluindo toda a cadeia de ácidos orgânicos voláteis (incluindo o acetato), diversos ácidos aromáticos, hidrogênio, metanol, etanol, glicerol, açucares, aminoácidos e diversos compostos fenólicos. Atualmente, as BRS podem ser divididas em dois grupos principais: (i) um grupo de espécies que é capaz de degradar compostos orgânicos, de modo incompleto, a acetato; e (ii) outro grupo que degradam compostos orgânicos, de modo completo, a dióxido de carbono (MUYZER \& STAMS, 2008).

Tipicamente, compostos orgânicos poliméricos, tais como o amido, celulose, proteínas, ácidos nucleicos (DNA e RNA) e as gorduras não são substratos diretos para as BRS. Portanto, na natureza, as BRS são dependentes de outros microrganismos que degradam esses substratos poliméricos e os fermentam para os produtos que são substratos para elas (MUYZER \& STAMS, 2008).

Também para Muyzer e Stams (2008), sob condições de disponibilidade insuficiente de sulfato para a oxidação de compostos orgânicos, as BRS competem umas 
com as outras pelo sulfato disponível, utilizando o hidrogênio, lactato e etanol como substrato, mas não o propionato e acetato. É provável que, sob limitações de disponibilidade de sulfato, o sintrofismo entre comunidades possua um papel na degradação de ácidos orgânicos, em que as metanogênicas hidrogenotróficas são substituídas pelas redutoras de sulfato utilizadoras de hidrogênio.

Embora aparentemente as BRS competem com os microrganismos fermentativos, acetogênicos e metanogênicos pelo substrato disponível resultando em um decréscimo da produção de metano, para baixas relações entre sulfato e a demanda química de oxigênio (DQO) observa-se que o sintrofismo ao invés da competição prevalece (DAMIANOVIC \& FORESTI, 2009).

Portanto, por meio das rotas metabólicas mencionadas, a digestão anaeróbia de compostos orgânicos contempla diversos tipos de microrganismos metanogênicos, sulfetogênicos e acidogênicos, sendo o equilíbrio ecológico entre os tipos e as espécies de microrganismos anaeróbios, de fundamental importância para a eficiência do sistema de tratamento.

Quando as populações de microrganismos metanogênicos encontram-se presentes em quantidades adequadas e a condição ambiental do meio no sistema de tratamento é favorável, os ácidos intermediários bem como o hidrogênio são tão rapidamente utilizados na velocidade em que são formados. Consequentemente, os ácidos não acumulam além da capacidade de tamponamento do meio, o pH se mantem em uma faixa adequada para os microrganismos metanogênicos, as concentrações e a relação entre o dióxido de carbono e o metano no biogás permanecem estáveis e o processo anaeróbio permanece em equilíbrio para a formação de metano.

A formação de metano em reatores anaeróbios é altamente desejada, pois por meio deste processo a matéria orgânica, geralmente medida como demanda química de oxigênio, é efetivamente removida, devido à baixa solubilidade em água apresentada pelo metano. Procura-se, então, proporcionar condições favoráveis para acelerar o processo de digestão anaeróbio, envolvendo tanto a concepção e o projeto do sistema de tratamento, quanto suas condições de operação. Em relação ao projeto de sistemas de tratamento, uma grande quantidade de microrganismos ativos e o bom contato entre a matéria orgânica presente no afluente e a massa microbiana contida no sistema são requeridos. Relacionado às condições operacionais, a alcalinidade, a temperatura, a produção e composição do biogás, o pH, a presença de elementos nutricionais e a ausência de materiais tóxicos no afluente são os fatores que mais influenciam (FORESTI et al., 1999). 


\subsection{REATORES ANAERÓBIOS TRATANDO ESGOTOS SANITÁRIOS}

O processo de tratamento biológico de águas residuárias torna-se economicamente vantajoso quando baixos tempos de detenção hidráulica e tempos suficientemente longos de retenção de sólidos, permitindo o crescimento dos microrganismos, são aplicados. Este foi por muitos anos o grande problema da digestão anaeróbia, com o tempo de retenção celular não podendo ser controlado independentemente do tempo de detenção hidráulica. Deste modo, os microrganismos envolvidos no processo, os quais possuem baixa velocidade de crescimento, necessitavam de longos tempos de retenção celular e consequentemente reatores com grande volume reacional. O desenvolvimento de processos anaeróbios de alta taxa solucionou este problema, uma vez que estes processos são capazes de permitir a presença de grande quantidade de biomassa ativa no reator, mesmo submetido a baixos tempos de detenção hidráulica. Se garantido o adequado contato entre a biomassa e o substrato, altas cargas volumétricas poderão ser aplicadas ao sistema.

Entre as décadas de 1950 e 1980, diversas configurações de reatores anaeróbios foram desenvolvidas para o tratamento de águas residuárias industriais (McCARTY, 1982), sendo as mais bem sucedidas: (i) o filtro anaeróbio (AF - Anaerobic Filter), de escoamento ascendente e contendo material suporte para a adesão da biomassa (YOUNG \& McCARTY, 1969); (ii) o reator anaeróbio de leito expandido/fluidificado (AAFEB Anaerobic Attached Film Expanded Bed e FB - Fixed Film Fluidized Bed), de escoamento ascendente e leito expandido/fluidificado contendo suporte para adesão da biomassa (SWITZENBAUN \& JEWELL, 1980); (iii) o reator de manta de lodo e escoamento ascendente (UASB), contendo um dispositivo interno para a separação das fases gás-líquido-sólido que mantem a biomassa dentro da zona reacional (LETTINGA et al., 1980).

Ainda na década de 1980, mudanças simples mas importantes no projeto de filtros anaeróbios de escoamento ascendente, como a redução de $50 \%$ a $75 \%$ do volume de material suporte em relação ao volume do reator, propiciaram o surgimento do reator anaeróbio híbrido (GUIOT \& van den BERG, 1984). Este tipo de reator de escoamento ascendente, consiste em um leito de lodo na parte inferior contendo biomassa autoimobilizada e na parte superior um leito estacionário contendo material suporte para adesão da biomassa, incorporando assim, as vantagens de sistemas de tratamento contendo células auto-imobilizadas (UASB) e imobilizadas (AF), enquanto elimina os 
problemas hidráulicos encontrados nos filtros anaeróbios (HALL, 1984; REYNOLDS \& COLLERAN, 1986).

Na década de 1990, a partir da concepção do reator UASB, os pesquisadores da área de tratamento de águas residuárias direcionaram as pesquisas para tal configuração, baseado nos resultados bem sucedidos obtidos por Lettinga e colaboradores (1980), com o objetivo de consolidar a tecnologia para o tratamento de águas residuárias.

Os avanços da aplicação do reator UASB para o tratamento de efluentes industriais e esgotos sanitários, aliados às pesquisas intensivas sobre o sistema, resultaram em consolidação da tecnologia para aplicação em vários tipos de indústria e diversas condições ambientais. No entanto, os estudos científicos e tecnológicos desenvolvidos, também foram de extrema importância para ressaltar os pontos negativos da tecnologia e as condições adversas para sua aplicação prática, como a complexidade do fenômeno de granulação do lodo e as baixas velocidades ascensionais aplicadas ao leito. Neste direcionamento, o mesmo grupo propôs a concepção do reator EGSB - Expanded Granular Sludge Bed (van der LAST \& LETTINGA, 1992; KATO et al., 1994), o qual permite a aplicação de altas velocidades ascensionais em sistema contendo biomassa auto-imobilizada ou aderida a algum suporte inerte (ZAIAT, 2003). Na mesma década de 1990, foi desenvolvido o reator IC - Internal Circulation, também uma variante do reator UASB, contendo dispositivos internos para a separação das fases gás-líquido-sólido em dois estágios, permitindo a aplicação de altas cargas orgânicas volumétricas, além da aplicação de altas velocidades ascensionais em sistema contendo biomassa autoimobilizada ou aderida a algum suporte inerte.

Para os sistemas acima mencionados, a digestão anaeróbia aplicou-se de maneira adequada para águas residuárias com altas concentrações de substrato e somente em condições de temperatura acima de $20-25^{\circ} \mathrm{C}$ (KALOGO \& VERSTRAETE, 2000), de modo que as primeiras configurações de reatores anaeróbios de alta taxa foram concebidos para o tratamento de efluentes industriais.

Os estudos para a aplicação de reatores anaeróbios de alta taxa no tratamento águas residuárias com baixas concentrações de substrato, como os esgotos sanitários, iniciaram com Lettinga e colaboradores (LETTINGA et al., 1983; de MAN et al., 1986; LETTINGA et al., 1987; de MAN et al., 1988) ao final da década de 1970, mostrando-se promissores, mesmo que o sucesso de sua aplicação e operação em larga escala ainda esteja limitada a regiões tropicais e subtropicais (sem necessidade de aquecimento), onde geralmente a temperatura do esgoto sanitário é superior a $20^{\circ} \mathrm{C}$ (van HAANDEL \& 
LETTINGA, 1994; LETTINGA, 2001). No entanto, a presença de sólidos em suspensão (incluindo óleos e graxas) nos esgotos sanitários bruto é um inconveniente para o seu tratamento em reatores anaeróbios (FORESTI et al., 2006).

Os sólidos em suspensão correspondem a aproximadamente $50 \%$ do total da demanda química de oxigênio (DQO) dos esgotos sanitários, fazendo com que a hidrólise seja a etapa limitante do processo de digestão anaeróbia (FORESTI et al., 2006). Portanto, algumas configurações de reatores anaeróbios aplicados com sucesso para o tratamento de efluentes industriais não podem ser aplicados para o tratamento de esgotos sanitários brutos, pois com os sólidos em suspensão presentes no afluente há o entupimento dos leitos fixos (ZAIAT et al., 2000; JAWED \& TARE, 2000), ou não serão retidos adequadamente (e posteriormente digeridos) nestes reatores anaeróbios submetidos a altas velocidades ascensionais (MAHMOUD et al., 2003).

Já na década de 2000, Zaiat, Passig e Foresti (2000) desenvolveram e aplicaram o reator RAHLF - Reator Anaeróbio Horizontal de Leito Fixo, de escoamento horizontal próximo ao pistonado, contendo espuma de poliuretano como material suporte inerte para adesão da biomassa tratando esgotos sanitários, devido a necessidade de se estudar reatores anaeróbios com base em fenômenos fundamentais que resultassem em modelos reacionais consistentes para possibilitar o aumento de escala.

Dentre os reatores em desenvolvimento na atualidade destacam-se os reatores de leito expandido e fluidificado, os reatores de leito fixo, os reatores em batelada sequencial, os reatores de circulação interna, os reatores anaeróbios híbridos e os reatores de membrana. Todos estes sistemas possuem em comum a utilização de células imobilizadas em suporte ou auto-imobilizadas, com exceção do reator de membrana, que se baseia nos reatores anaeróbios de contato, utilizando sistema de separação de membranas para manutenção da biomassa no sistema.

Os sistemas anaeróbios de alta taxa mais comumente utilizados no tratamento de esgotos sanitários são classificados, por conveniência, de acordo com o tipo de crescimento da biomassa no sistema, como apresentados na Figura 3.2 e descritos a seguir. 


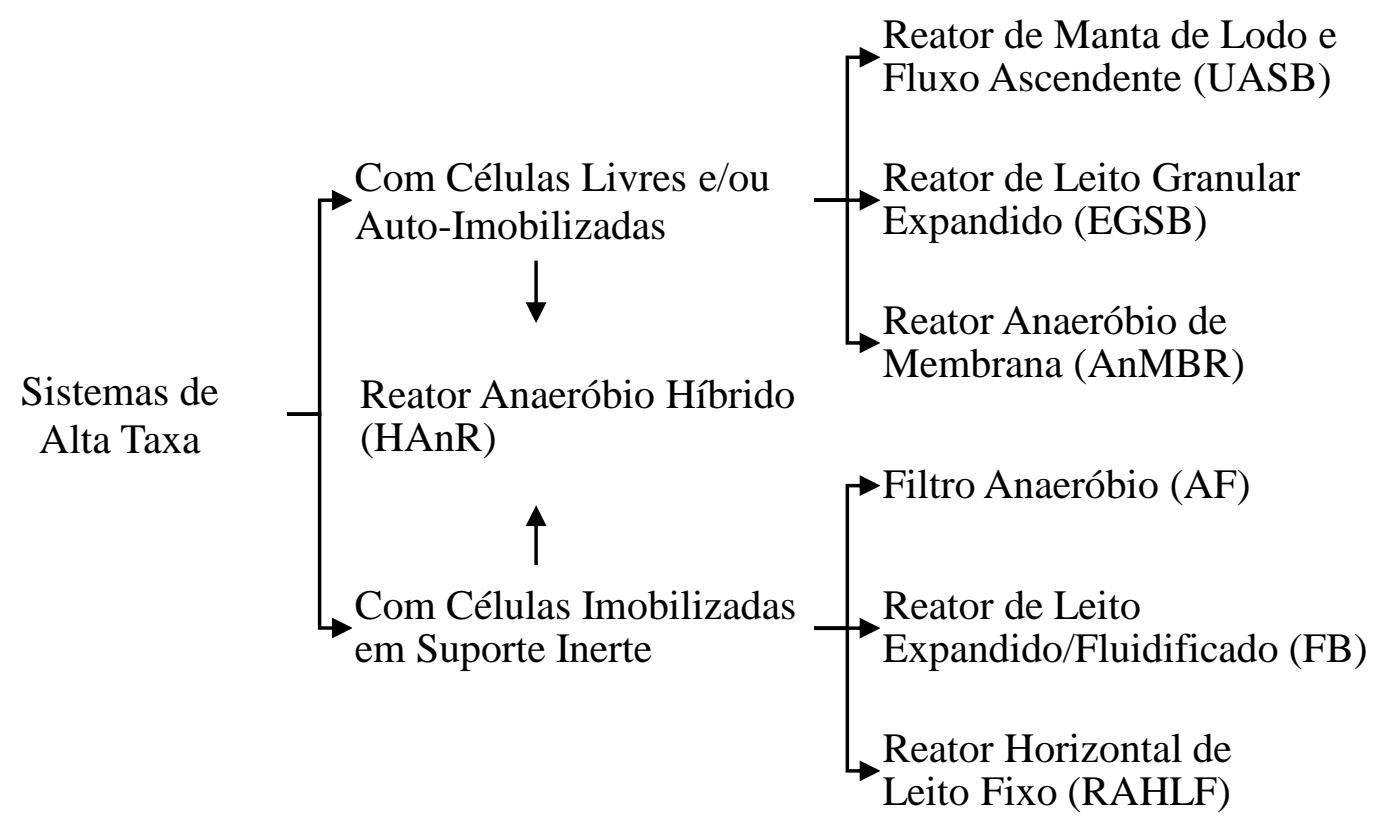

Figura 3.2 - Classificação usual para sistemas anaeróbios de alta taxa tratando esgotos sanitários.

O conceito de crescimento em suspensão ou disperso é associado a presença de células livres, flocos ou grânulos de células auto-imobilizadas. Já o crescimento aderido é associado a presença de células imobilizadas a um material suporte inerte (formação de biofilme).

Sob o prisma da sustentabilidade, Lettinga et al. (1997), enfatiza a necessidade de implementação de sistemas de proteção ambiental integrados que conciliem o tratamento de esgotos sanitários, sua recuperação e reuso como coproduto. A abordagem tem um apelo especial aos países em desenvolvimento, que apresentam sérios problemas ambientais, falta de recursos e de energia e, muitas vezes, a produção insuficiente de alimentos. Neste contexto, a digestão anaeróbia torna-se uma excelente alternativa de integração para o tratamento de esgotos sanitários e a recuperação de coprodutos, como apresentado na Figura 3.3. 


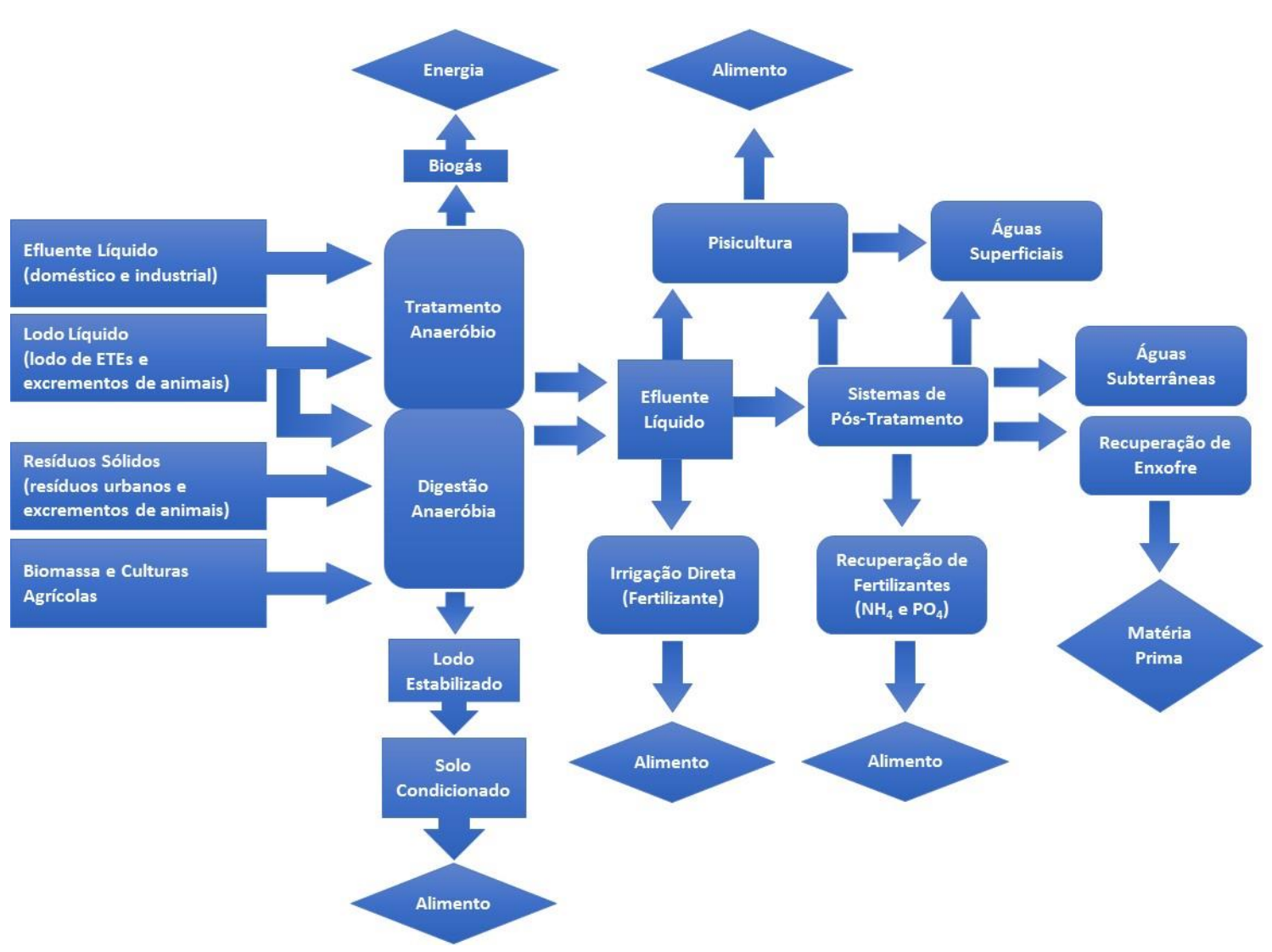

Figura 3.3 - Conversão biológica em processos aeróbios e anaeróbios (Adaptado de: LETTINGA et al., 1997).

Foresti et al. (2006) também evidenciam que a melhoria da sustentabilidade dos sistemas de tratamento de esgotos sanitários, passa pela utilização de processos anaeróbios como alternativa tecnológica, bem como pela incorporação de ideias recentes obtidas em pesquisas de pré- e pós-tratamento e novas configurações de reatores anaeróbios, tanto para melhorar a conversão da matéria orgânica, quanto para a recuperação de energia e recursos, como os compostos de nitrogênio, fósforo e enxofre.

Foresti et al.(2006) complementam dizendo que a situação ideal para sistemas de tratamento de esgotos sanitários seria a completa remoção de patógenos (proteção à saúde pública) e a máxima remoção de matéria orgânica (proteção ao meio ambiente) conjugadas com a recuperação de energia (metano e/ou hidrogênio) e compostos de interesse: nitrogênio (como nitrogênio amoniacal, nitrito e nitrato), fósforo (como fosfato) e enxofre (como enxofre elementar). Deste modo, em termos de sustentabilidade, o uso de reatores anaeróbios como unidade principal destes sistemas é extremamente promissor para este fim.

Neste contexto, o desenvolvimento de unidades de pós-tratamento se faz necessário não somente para melhorar a qualidade do efluente destes reatores anaeróbios 
tratando esgotos sanitários, que em sua grande maioria produzem efluentes com concentrações médias variando entre 100 a $200 \mathrm{mg}$ DQO.L ${ }^{-1}, 50$ a $100 \mathrm{mg} \mathrm{SST.L^{-1 }}$ (VIEIRA, 1988; van HAANDEL \& LETTINGA, 1994; PASSIG et al., 2000), 30 a 50 mg $\mathrm{NH}_{3} . \mathrm{L}^{-1}$ (KOBAYASHI et al., 1983; TORRES \& FORESTI, 2001) e 10 a 17 mg P.L - $^{-1}$ (TORRES \& FORESTI, 2001), não atendendo aos padrões e exigências necessárias para seu lançamento direto em corpos d'água superficiais, mas também para alcançar a recuperação dos recursos citados anteriormente.

Chernicharo (2007), em relação aos processos aeróbios convencionais, afirma que são diversas as características favoráveis que proporcionam aos sistemas anaeróbios de alta taxa um grande potencial para sua aplicação no tratamento de esgotos sanitários. Além de sua simplicidade, do baixo custo tecnológico, também possuem algumas vantagens relacionadas a operação e manutenção.

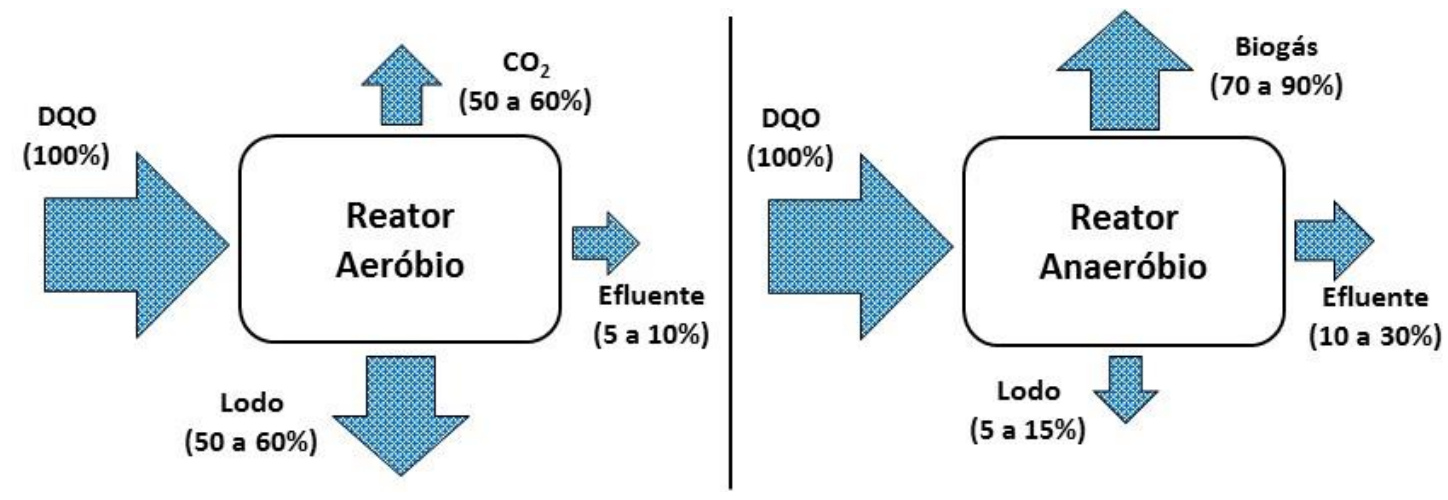

Figura 3.4 - Conversão biológica em processos aeróbios e anaeróbios (Adaptado de: CHERNICHARO, 2007).

Na Figura 3.4 é possível visualizar algumas vantagens da digestão anaeróbia em relação ao tratamento aeróbio, notadamente em relação a produção de metano e a baixa produção de biomassa.

\subsubsection{Reator Anaeróbio de Manta de Lodo e Escoamento Ascendente}

O reator anaeróbio de manta de lodo e escoamento ascendente (UASB) foi desenvolvido por Lettinga e colaboradores (1980), tendo sido aplicado inicialmente na Holanda. O processo consiste essencialmente de um escoamento ascendente do afluente através de um leito denso de lodo, com alta atividade microbiana. O perfil de sólidos no reator varia de partículas muito densas e granulares com boa sedimentabilidade próximas 
ao fundo (leito de lodo) para partículas mais dispersas e leves próximo ao topo do reator (manta de lodo).

A conversão da matéria orgânica ocorre em todo o volume reacional do reator (leito e manta de lodo) e a mistura do sistema é proporcionada pelo escoamento ascendente do afluente bem como pelo movimento das bolhas de biogás. O afluente entra pela parte inferior e o efluente deixa o reator por meio de um compartimento interno de decantação localizado na parte superior do reator. O separador gás-líquido-sólido (separador trifásico), localizado abaixo da câmara de decantação garante uma ótima condição de sedimentação para as partículas que escapam da manta de lodo, permitindo seu retorno à câmara de digestão ao invés de deixar o sistema. Embora parte destas partículas leves escapem do sistema juntamente com o efluente, o tempo médio de retenção de sólidos no reator permanece suficientemente alto favorecendo o crescimento e a formação de uma densa massa microbiana metanogênica, mesmo aplicando-se baixos tempos de detenção hidráulica.

Um dos princípios fundamentais do processo é a habilidade de desenvolver uma biomassa altamente ativa. Esta biomassa pode apresentar-se na forma de flocos ou grânulos (da ordem de 1 a $5 \mathrm{~mm}$ de diâmetro), sendo que o lodo de maior densidade concentra-se próximo ao fundo do reator, apresentando uma concentração de sólidos

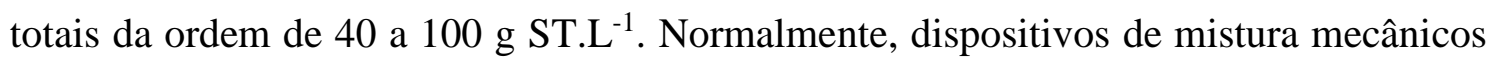
não são utilizados, uma vez que apresentam um efeito adverso na formação de agregados de lodo e, consequentemente, na formação de grânulos.

O segundo princípio fundamental do processo é a presença do dispositivo de separação gás-líquido-sólido, localizado no topo do reator. A principal finalidade deste dispositivo é a separação dos gases, bem como dos sólidos contidos na mistura líquida, de modo a favorecer uma zona de sedimentação na parte superior do reator.

A tecnologia do reator UASB é extremamente simples, como apresentado na Figura 3.5, e não requer a instalação de nenhum dispositivo sofisticado ou mesmo a utilização de material suporte para imobilização e retenção de biomassa. 


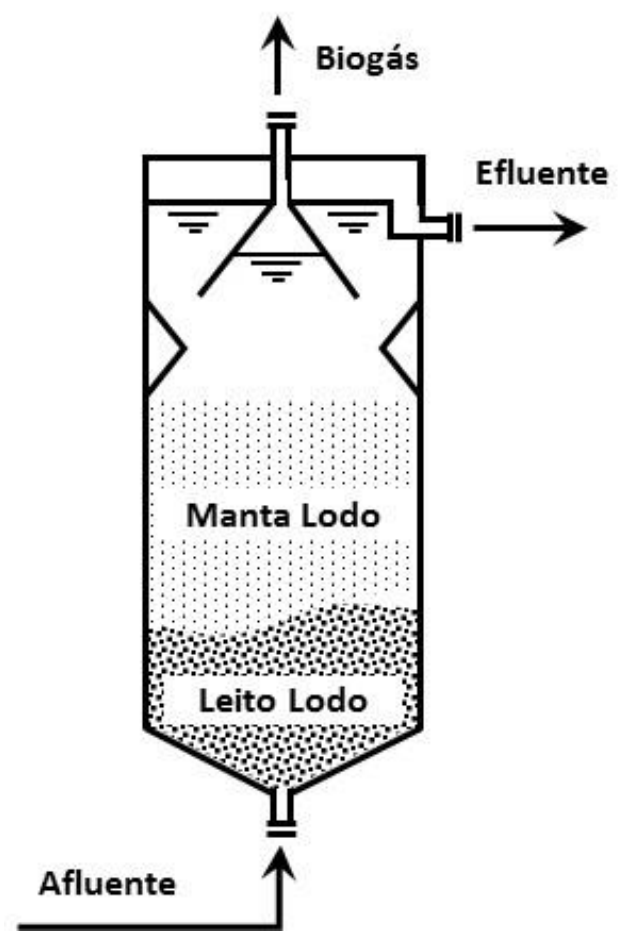

Figura 3.5 - Esquema representativo do reator UASB.

O processo foi inicialmente desenvolvido para tratar águas residuárias concentradas (efluentes agroindustriais), obtendo ótimos resultados. Entretanto, em regiões tropicais e subtropicais, os reatores UASB também foram aplicados para o tratamento de águas residuárias diluídas, como os esgotos sanitários, obtendo bons resultados, mas com algumas limitações (LETTINGA \& HULSHOFF, 1991; SCHELLINKHOUT \& OSARIO, 1992; SINGH \& VIRARAGHAVAN, 2003).

Foresti et al. (2006) afirmam que a aplicação do reator UASB ainda está restrita aos países tropicais e subtropicais, onde a maioria dos países em desenvolvimento estão localizados, constituindo um nicho privilegiado para a aplicação vantajosa do processo anaeróbio como o centro da tecnologia para o tratamento de esgotos sanitários. Para temperaturas superiores a $20^{\circ} \mathrm{C}$, cargas orgânicas volumétricas inferiores a $3,0 \mathrm{~kg}$ DQO. $\mathrm{m}^{-3} \cdot \mathrm{d}^{-1}$ e tempo de retenção celular da ordem de 6 a $10 \mathrm{~h}$, eficiências de remoção de $65 \%$ a $80 \%$ para DQO e DBO, e de $67 \%$ a $90 \%$ para SST foram obtidos com reatores UASB (ELMITWALLI et al., 1999; PASSIG et al., 2000; FLORENCIO et al., 2001; WIEGNANT, 2001; FORESTI, 2001; LEITÃO, 2004; LEITÃO et al., 2005). Apesar do reconhecido sucesso do reator UASB como a unidade anaeróbia mais eficiente e utilizada para o tratamento de esgotos sanitários bruto, algumas limitações desta tecnologia são evidentes. A formação de escuma dentro do separador trifásico e altas perdas de sólidos 
em suspensão voláteis (SSV) no efluente são questões sérias que merecem a devida atenção para a melhoria do projeto do reator, assim, presumivelmente, permitindo melhora em seu desempenho.

Sem dúvida nenhuma, os reatores UASB são o sistema anaeróbio de alta taxa mais comumente utilizados no tratamento de esgotos sanitários. São mais de 1.000 unidades em escala real implantadas em todo o mundo (TIWARI et al., 2006). No entanto, ainda há questões não resolvidas nesta tecnologia de tratamento anaeróbio.

O sucesso e ao mesmo tempo os problemas que os reatores UASB apresentaram fazem com que o sistema esteja no foco de intensa pesquisa em todo o mundo para o tratamento de efluentes sanitários e industriais.

Em geral, o comportamento dinâmico dos reatores UASB são afetados por mudanças nos fatores externos, mas a gravidade do efeito é dependente do tipo, magnitude, duração e frequência das perturbações impostas. As respostas típicas incluem uma diminuição do desempenho, acúmulo de ácidos orgânicos voláteis, queda do $\mathrm{pH}$ e alcalinidade, a mudança na produção e composição do biogás e a perda de sólidos suspensos voláteis no efluente (FORESTI et al., 2006; LEITÃO et al., 2006). Fatores ambientais e operacionais governam o desempenho dos reatores UASB tratando esgotos sanitários, a saber: (i) característica dos esgotos sanitários bruto (concentração, a biodegradabilidade, a fração insolúvel e a sedimentabilidade da fração particulada); (ii) condições operacionais (temperatura, carga orgânica e hidráulica, tempo de detenção hidráulica, tempo de retenção celular e velocidade ascensional); e (iii) característica do lodo desenvolvido (forma, distribuição de tamanho de partículas, substâncias poliméricas extracelulares e cargas).

Carvalho (2006), também afirma que os sistemas de tratamento de esgotos sanitários podem ser expostos a diversas variações, tais como: (i) variações na composição dos esgotos ao longo do dia devido à natureza cíclica das atividades humanas (HANAI, 1997; OLIVA, 1997; METCALF \& EDDY, 2003); (ii) variações de vazão ao longo do ano devido à presença de população flutuante em períodos de férias e áreas turísticas; e (iii) sobrecargas hidráulicas e orgânicas resultantes de procedimentos operacionais adotados nas estações de tratamento de esgotos (BORJA \& BANKS, 1995; OLIVA, 1997; BRITO \& MELO, 1999). 


\subsubsection{Influência da Característica dos Esgotos Sanitários Bruto}

De modo geral, o esgoto doméstico apresenta grandes variações em sua composição devido à influência de fatores como o número de habitantes e domicílios conectados à rede de esgotamento sanitário, uso e costume da população, a característica específica da rede coletora (tipo, material, comprimento, manutenção, uso de estações de bombeamento), bem como do clima, topografia, contribuições industriais e comerciais e contribuições clandestinas de águas pluviais.

A abordagem tradicional para estimar a vazão de esgoto de um sistema do tipo separador absoluto de esgotamento sanitário, assume um volume médio diário per capto e utiliza multiplicadores para estimar o volume nos períodos de maior e menor geração (METCALF \& EDDY, 2003; BUTLER et al., 1995; CAMPOS \& von SPERLING, 1996). Campos e von Sperling (1996) reportaram que as principais características dos esgotos sanitários variam de acordo com a hora do dia e o dia da semana, além de depender da classe socioeconômica familiar.

Wang (1994) e Odegaard (1999) identificaram que alguns processos biológicos e físico-químicos iniciam ainda nas redes de esgotamento sanitário, antes mesmo de atingirem as estações de tratamento. Nesse contexto, Odegaard (1999) observou que para regiões de relevo acidentado, prevalecem condições geralmente aeróbias nos esgotos e no biofilme estabelecido na parede das tubulações que compõe os sistemas de esgotamento, resultando no decréscimo da quantidade de matéria orgânica solúvel e no aumento da matéria orgânica particulada. Por outro lado, em regiões de relevo pouco acidentado, condições anaeróbias prevalecerão e a matéria orgânica particulada será capturada/adsorvida pelo biofilme e hidrolisada à substratos solúveis e partículas de menor dimensão.

Hanai (1997) e Oliva (1997) verificaram contribuições simultâneas de águas residuárias e águas pluviais (clandestinas) nas cidades de Araraquara e São Carlos, Brasil, respectivamente, que causaram sobrecargas hidráulicas no sistema do tipo separador absoluto de esgotamento sanitário como nas unidades de tratamento de esgotos, prejudicando os processos biológicos devido ao aumento da DQO afluente, principalmente em dias chuvosos. Os mesmos autores observaram que a contribuição de esgoto industrial promoveram variações dos parâmetros DQO, $\mathrm{pH}$ e temperatura, sendo que Hanai (1997) verificou picos máximos iguais a $3.076 \mathrm{mg}$ DQO.L $\mathrm{L}^{-1}, 11$ e $35^{\circ} \mathrm{C}$, respectivamente. 
Oliva (1997) constatou variações da ordem de $103 \%$ entre a DQO mínima e máxima durante a semana e variações de $117 \%$ entre a DQO mínima e máxima ao longo do dia. As principais variações encontradas foram em relação as proteínas (260\%), carboidratos (1.003\%) e lipídeos (650\%) durante a semana e 171\%, 302\% e $150 \%$ ao longo do dia, respectivamente.

Orhon e colaboradores (1997) notaram concentrações elevadas de surfactantes (da ordem de $160 \mathrm{mg} . \mathrm{L}^{-1}$ a $760 \mathrm{mg} . \mathrm{L}^{-1}$ ) e de cloro (da ordem de $1.000 \mathrm{mg} . \mathrm{L}^{-1}$ ) em áreas que recebiam contribuições industriais de um complexo de curtumes na cidade de Istambul, Turquia. Os mesmos pesquisadores também verificaram concentração média de matéria orgânica de aproximadamente $1.000 \mathrm{mg}$ DQO.L $\mathrm{L}^{-1} \mathrm{em}$ área residencial menos favorecida da região metropolitana de Istambul que sofre com falta de abastecimento de água.

Muito embora, a matéria orgânica apresenta-se em baixas concentrações nos esgotos sanitários, tipicamente da ordem de 250 a 1.000 mg DQO.L ${ }^{-1}$ (TCHOBANOGLOUS \& BURTON, 1991; CRITES \& TCHOBANOGLOUS, 1998), Lettinga e Hulshoff Pol (1991) consideram esta água residuária como complexa, parcialmente solúvel, devido à elevada fração da DQO presente na forma de sólidos particulados, da ordem de 45 a 55\% (WANG, 1994; ODEGAARD, 1999; KALOGO \& VERSTRAETE, 2001; MAHMOUD et al., 2003), bem como à presença de óleos e graxas, proteínas, surfactantes e outros compostos desconhecidos (FORESTI, 2001).

Neste contexto, baixas concentrações de DQO no afluente resultam em baixos níveis de substrato no volume reacional do reator UASB. Consequentemente, no que tange a cinética de Monod, baixas velocidades específicas de crescimento bem como baixas velocidades específicas de consumo de substrato prevalecerão, o que poderá, eventualmente, resultar em um baixo desempenho do reator UASB. Ademais, a baixa produção de biogás esperada para o tratamento de águas residuárias diluídas, devido ao baixo contato entre o substrato e a biomassa (menor grau de mistura proporcionada pelo movimento das bolhas de biogás na massa líquida), reduz os benefícios econômicos provenientes da produção de energia (KATO \& LETTINGA, 1994).

Neste mesmo contexto, Teixeira e colaboradores (2005) afirmam que a matéria orgânica particulada pode contribuir significativamente para a demanda química de oxigênio efluente de reatores UASB, e pode ser constituída tanto por biomassa arrastada do reator como por material particulado originalmente presente no afluente. Ainda que a maior parte da matéria orgânica particulada presente no esgoto bruto seja biodegradável, a degradação apenas parcial desse material pode ocorrer devido a vários fatores. A 
presença de caminhos preferenciais na manta de lodo do reator UASB caracterizaria um curto-circuito hidráulico, o que diminuiria o tempo de detenção hidráulico e, consequentemente, o tempo de contato entre a biomassa e potenciais substratos. Ademais, a elevada presença de materiais particulados no afluente pode dificultar a hidrólise desses compostos limitando a degradação da matéria orgânica, uma vez que a hidrólise, etapa inicial da decomposição anaeróbia, ocorre, normalmente, de forma mais lenta que as reações subsequentes (VAVILIN et al., 1996).

Materiais particulados representam a maior fração nos esgotos sanitários, afirmam Elmitwalli e colaboradores (2000). Wang (1994) mostrou que partículas orgânicas, superiores a $0,45 \mu \mathrm{m}$, representam cerca de $70 \%$ do esgoto sanitário bruto e Levine e colaboradores (1985) verificaram também que a contribuição das partículas orgânicas maiores que $0,1 \mu \mathrm{m}$ variaram entre $30 \%$ a $85 \%$ em relação à quantidade total da matéria orgânica presente no esgoto sanitário.

Elmitwalli e colaboradores (2001) afirmam que, em reatores anaeróbios, as partículas são convertidas pela hidrólise depois de serem fisicamente removidas por adsorção, sedimentação ou aderidas ao leito de lodo, ou seja, a remoção de material particulado dos esgotos sanitários ocorrem principalmente por meio de processos físicos provenientes da biomassa anaeróbia (atuando como um filtro biológico) presente no sistema. Consequentemente, são requeridos maiores tempos de detenção hidráulicas para a completa solubilização da matéria orgânica em sistemas de tratamento de efluentes com elevadas concentrações de sólidos suspensos. De acordo com Aiyuk e colaboradores (2006), os sólidos suspensos podem diminuir a atividade da biomassa, no que tange à adsorção e interceptação, e limitar a transferência de substratos. Deste modo, a presença de material particulado no efluente dificulta o atendimento aos requisitos da legislação ambiental brasileira e, por isso, é importante conceber sistemas de tratamento que favoreçam a sua degradação em reatores anaeróbios.

Teixeira e colaboradores (2005) também ressaltam que a distribuição do tamanho de partículas nos esgotos influencia os aspectos físicos dos reatores, uma vez que a dimensão das partículas influencia as velocidades de sedimentação, adsorção e difusão (LEVINE et al., 1985). Por exemplo, nos tratamentos anaeróbios de alta taxa, a DQO coloidal dos esgotos domésticos é removida em taxas menores que sob condições aeróbias devido à baixa retenção física das partículas coloidais que, em tese, permanecem dentro dos reatores apenas pelo tempo equivalente ao tempo de detenção hidráulico (WANG et al., 1995; ELMITWALLI, 2001). 


\subsubsection{Influência das Condições Operacionais}

Na digestão anaeróbia, um delicado balanço existe entre as etapas iniciais (hidrólise e acidogênese) e a conversão de seus produtos ácidos à metano e dióxido de carbono, pela etapa metanogênica (COHEN et al., 1982).

De acordo com van Lier et al. (2001), Leitão (2006) e Carvalho (2006), grandes variações de vazão e concentração do afluente podem afetar negativamente a eficiência de um reator UASB. O efeito da flutuação das cargas hidráulica e orgânica, geralmente, depende do tempo de detenção hidráulico aplicado, do tempo de retenção celular, da intensidade e duração das variações, das propriedades do lodo e do projeto dos reatores, particularmente da configuração do separador trifásico.

O acúmulo de ácidos voláteis pode ser uma resposta típica do reator quando submetido a sobrecarga e bruscas variações das cargas hidráulica e orgânica. A pressão parcial de hidrogênio desempenha um papel importante no controle da produção e proporções de vários produtos intermediários da digestão anaeróbia. Sob condições de sobrecarga ou de grandes variações, pode haver uma mudança na rota metabólica para uma rota menos favorável, resultando no desequilíbrio entre os organismos que produzem (acidogênicos e acetogênicos) e os que consomem (metanogênicos, BRS e BRN bactérias redutoras de nitrogênio) os ácidos voláteis e, consequentemente, na produção indesejada de quantidades significativas de dióxido de carbono e gás hidrogênio no biogás. Deste modo, a pressão parcial de hidrogênio gasoso no interior do reator pode aumentar para valores superiores a $10^{-4}$ atm, podendo causar, portanto, uma mudança na rota metabólica. Quando os microrganismos metanogênicos não conseguem consumir o hidrogênio na mesma velocidade com que é produzido pelas bactérias produtoras de hidrogênio, isto pode resultar em uma inibição e, consequentemente, no acúmulo de propianato, butirato e lactato no meio (COHEN et al., 1982; ENG et al., 1986; CÁNOVAS-DÍAZ \& HOWELL, 1988; FONGASTITKUL et al., 1994). Outra reposta típica do reator submetido a sobrecarga é a mudança drástica na produção e composição do biogás (CHUA et al., 1997).

Oliva (1997) conduziu experimentos com um reator UASB de $18 \mathrm{~m}^{3}$, tratando esgoto sanitário proveniente da rede de esgotamento sanitário da cidade de São CarlosSP, com o objetivo de avaliar os efeitos de sobrecargas hidráulicas e a continuidade de seus possíveis efeitos por meio do aumento da vazão afluente. Após ter alcançado o estado de equilíbrio dinâmico aparente, o reator foi operado com TDH de 8 h, vazão média 
afluente de 2,25 $\mathrm{m}^{3} \cdot \mathrm{h}^{-1}$, carga orgânica volumétrica média de 2,7 $\mathrm{kg}$ DQO.m $\mathrm{m}^{-3}$ e carga orgânica de $48 \mathrm{~kg}$ DQO. $\mathrm{d}^{-1}$. Nessas condições operacionais o reator apresentou eficiências médias de remoção de $77 \pm 6 \%$ para DQO bruta e $86 \pm 6 \%$ para DQO filtrada.

A autora realizou ensaios de resposta dinâmica com aplicação de sobrecarga hidráulica de cinquenta por cento $\left(3,4 \mathrm{~m}^{3} \cdot \mathrm{h}^{-1}\right)$, duas vezes por dia, em relação a vazão normal de operação, constatando que esse pulso de vazão não afetou de modo significativo o desempenho do reator. As eficiências médias obtidas para a remoção de DQO variaram de $81 \pm 5 \%$ às $9 \mathrm{~h}, 77 \pm 3 \%$ às $12 \mathrm{~h}, 69 \pm 7 \%$ às $17 \mathrm{~h}$ e $68 \pm 7 \%$ às $20 \mathrm{~h}$.

Também foram realizados ensaios de resposta dinâmica com aplicação de sobrecarga hidráulica de cem por cento $\left(4,5 \mathrm{~m}^{3} \cdot \mathrm{h}^{-1}\right)$, uma vez por dia, que provocou o aumento da DQO efluente e arraste de sólidos no efluente do reator. As eficiências médias obtidas para a remoção de DQO variaram de $76 \pm 8 \%$ às $9 \mathrm{~h}$ e $69 \pm 8 \%$ às $13 \mathrm{~h}$. De acordo com os resultados apresentados, verificou-se que o reator tende a se adaptar, amortecendo às sobrecargas impostas.

Castillo e colaboradores (1997) investigaram o comportamento de um reator UASB em escala piloto (750 L), submetido a variações de TDH de 1,5 h, 3 h, 6 h e 7,5 h no verão $\left(\sim 20^{\circ} \mathrm{C}\right)$ e no inverno $\left(\sim 13^{\circ} \mathrm{C}\right)$. O reator foi alimentado com esgoto sanitário com DQO afluente de $600 \mathrm{mg} . \mathrm{L}^{-1}$.

Os autores observaram que as eficiências de remoção de DQO total, DQO solúvel e DQO particulada aumentaram com o aumento do TDH para ambas as estações do ano. Entretanto, para TDH maiores do que $6 \mathrm{~h}$ houve uma tendência destas eficiências tornarem-se constantes. Além disso foi possível constatar que, quando o reator foi operado no inverno, as eficiências de remoção de DQO total foram de 5\% a $15 \%$ inferiores àquelas observadas para o período do verão. Após cada variação da carga orgânica volumétrica (imposta pelo aumento do TDH), o reator demonstrou período de instabilidade antes de alcançar o estado de equilíbrio dinâmico aparente.

A velocidade ascensional $\left(\mathrm{v}_{\mathrm{s}}\right)$ é um dos principais fatores que afetam as eficiências de remoção de matéria orgânica e, principalmente, sólidos em suspensão de reatores UASB (GONÇALVES et al., 1994; WIEGANT, 2001; METCALF \& EDDY, 2003), quando a retenção do lodo está associado às características de sedimentação de seus agregados. Deste modo, a velocidade ascensional pode ser um fator limitante no que tange o volume reacional requerido do reator quando tratando esgotos sanitários (WIEGANT, 2001). 
Para Mahmoud e colaboradores (2003) a velocidade ascensional possui dois efeitos opostos, a saber: (i) por um lado, o aumento da velocidade ascensional aumenta as colisões entre as partículas em suspensão e o lodo e, portanto, podendo aumentar a eficiência de remoção dessas; (ii) por outro lado, o aumento da velocidade ascensional poderia aumentar a força de cisalhamento, opondo-se então ao mecanismo de remoção, excedendo a velocidade de sedimentação das partículas e desagregando os sólidos previamente capturados e, por conseguinte, deteriorando a eficiência de remoção dessas.

Gonçalves e colaboradores (1994) operando um reator anaeróbio de escoamento ascendente, tratando esgoto sanitário à $20^{\circ} \mathrm{C}$, com velocidades ascensionais de 3,2 (TDH de 1,1), 1,7 (TDH de 2,1), 1,6 (TDH de 2,3), 0,9 (TDH de 2,8), 0,75 (TDH de 3,3) e 0,6 m.h ${ }^{-1}$ (TDH de 4,3), observaram redução na eficiência de remoção de sólidos em suspensão, variando de 70\%SST $\left(0,75\right.$ e $\left.0,9 \mathrm{~m} \cdot \mathrm{h}^{-1}\right)$ para 51\%SST $\left(3,4 \mathrm{~m} \cdot \mathrm{h}^{-1}\right)$.

de Man e colaboradores (1986) obtiveram uma redução significativa na remoção de sólidos em suspensão quando velocidades ascensionais maiores que $0,50 \mathrm{~m} \cdot \mathrm{h}^{-1}$ foram aplicadas ao reator UASB, contendo lodo granular, no tratamento de esgoto sanitário. Wiegant (2001), no entanto, apresentou dados resumidos a partir da literatura demonstrando que não há uma tendência clara e significativa entre a redução na capacidade de remoção de sólidos e o aumento da velocidade ascensional, para valores compreendidos entre 0,50 a $1,50 \mathrm{~m} \cdot \mathrm{h}^{-1}$, no tratamento de águas residuárias em reatores UASB. Porém Wiegant (2001), justifica que esses resultados contraditórios podem ser explicados pela ocorrência de curtos-circuitos no leito de lodo.

Hang e Byeong (1990) afirmam que a velocidade ascensional deve ser alta o suficiente para proporcionar um bom contato entre o substrato e biomassa, bem como deve ser o suficiente para perturbar os bolsões de gás reunidos no leito de lodo. Acreditase portanto que quanto maior for a velocidade ascensional, maior será a separação das bolhas de biogás aderidas à superfície da biomassa.

\subsubsection{Influência da Característica do Lodo Desenvolvido}

As características físico-químicas do leito de lodo desempenham um papel central na capacidade de remoção de sólidos em suspensão de reatores UASB. Mahmoud e colaboradores (2003) apresentaram a hipótese (Figura 3.6) de que a interação entre as condições da digestão anaeróbia e as características físico-químicas da biomassa afetam 
o processo de separação sólido-líquido por meio da filtração através do leito de lodo em reatores UASB.

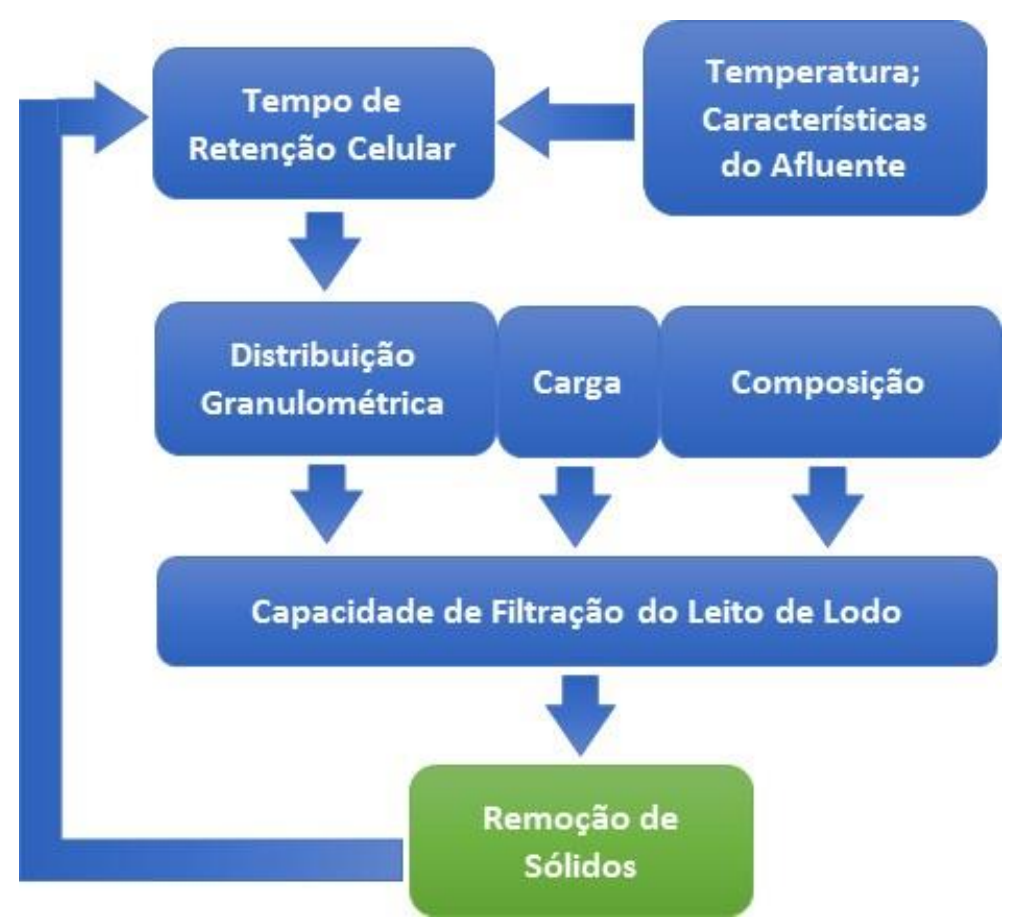

Figura 3.6 - Esquema de hipótese de interação para a remoção física de sólidos em suspensão em reator UASB (Fonte: Adaptado de MAHMOUD et al., 2003).

Mahmoud e colaboradores (2003) relataram que a característica física e química da biomassa é afetada principalmente pela presença de substâncias poliméricas extracelulares (EPS - Extracellular Polymeric Substances) de alto peso molecular, compostas principalmente por carboidratos e proteínas, produzidas pelos próprios microrganismos sob certas condições. Tais biopolímeros originam-se de diferentes fontes, a saber: (i) síntese biológica e excreção; (ii) lise de células bacterianas (MORGAN et al., 1990; FROLUND et al., 1996); e também (iii) adsorção da matéria orgânica, como celulose e ácidos úmicos presentes na água residuária afluente, na superfície do floco/grânulo/biofilme (MORGAN et al., 1990; URBAIN et al., 1993).

Deste modo, a excreção de EPS pode ser o principal fator a contribuir para a remoção de sólidos em suspensão na presença de biomassa, uma vez que a melhora na bioadsorção de partículas é creditada à estas substâncias (DUGAN, 1987; ELMITWALLI, 2000). Portanto, a presença de EPS pode aumentar as forças de resistência ao cisalhamento dos sólidos capturados.

Morgan e colaboradores (1990) investigando as diferenças entre biopolímeros extraídos de reatores do tipo lodos ativados, anaeróbio de leito fluidificado, filtro 
anaeróbio e UASB com biomassa floculenta e granular, constataram diferenças significativas, em termos de rendimento, entre a natureza das amostras de lodo. Todas as amostras provenientes dos reatores anaeróbios, em particular dos UASB, produziram significativamente menor quantidade de EPS quando comparadas às quantidades produzidas pelo reator de lodos ativados. As amostras de lodo dos reatores de leito fluidificado, filtro anaeróbio e reator UASB com biomassa floculenta, produziram quantidades intermediárias de EPS em relação às obtidas nas amostras dos reatores de lodos ativados (70 a $\left.90 \mathrm{mg} \mathrm{EPS.g}^{-1} \mathrm{SS}\right)$ e UASB com biomassa granular (10 a $20 \mathrm{mg}$ EPS.g $\left.{ }^{-1} \mathrm{SS}\right)$.

Jia e colaboradores (1996) investigando a produção, em termos de rendimento, de EPS em quatro lodos anaeróbios enriquecidos, individualmente, com acetato, propionato, butirato e glucose, constataram que o lodo acidogênico (glucose) produziu maior quantidade de EPS em comparação ao lodo acetogênico e ao lodo metanogênico.

Harada e colaboradores (1988) observaram que grânulos de reatores UASB degradando carboidratos eram maiores e possuíam maior resistência mecânica quando comparados à grânulos de reatores UASB degradando ácidos graxos de cadeia curta. Os pesquisadores também concluíram, por meio de microscopia eletrônica, que o EPS excretados pelas bactérias acidogênicas auxiliaram na ligação célula-célula, aumentando a resistência mecânica e a estabilidade estrutural do grânulo.

Elmitwalli e colaboradores (2000) atribuiram o aumento da eficiência de remoção de partículas coloidais em um filtro anaeróbio contendo espuma de poliuretano reticulada como meio suporte para a adesão da biomassa à produção de EPS.

Sprouse e Rittman (1991) demonstraram que o crescimento de biofilme anaeróbio em carvão ativado granular em um reator de leito fluidificado melhora a remoção de sólidos em suspensão.

Grupos ionizáveis dos EPS, tais como o grupo amina (- $\left.\mathrm{NH}_{2}\right)$, o grupo hidroxila $(-\mathrm{OH})$, o grupo carboxila (-COOH) e/ou por meio da adsorção de íons a partir da fase líquida, provavelmente influem na carga elétrica superficial da biomassa. A carga destes grupos é dependente da natureza dos grupos e do $\mathrm{pH}$. Em $\mathrm{pH}$ neutro, grupos funcionais como o grupo carboxila possui cargas negativa, enquanto que o grupo amina e outros grupos semelhantes possuem cargas positivas (MARSHALL, 1967; SUTHERLAND, 1984; HENZE et al., 1995; JIA et al., 1996; STUMM \& MORGAN, 1996).

Elmitwalli e colaboradores (2001) observaram que partículas de lodo anaeróbio possuem cargas negativas. 
Na literatura, muitos são os relatos de que as características físico-químicas de lodos, como o potencial de troca iônica (FLEMMING, 1995), a sedimentabilidade (STEINER et al., 1976; MAGERA et al., 1976; FORSTER \& DALLAS-NEWTON, 1980; ERIKSSON \& AXBERG, 1981), a desidratabilidade (POXON \& DARBY, 1997) e a viscosidade (FORSTER, 1981), são influenciadas pela carga superficial apresentadas por estes lodos.

Mahmoud e colaboradores (2003) concluíram que a carga superficial da biomassa é dependente, provavelmente, das condições da digestão anaeróbia, uma vez que está relacionada com a quantidade e composição dos EPS.

\subsubsection{Reator Anaeróbio de Leito Fixo}

O exemplo mais comum de reatores anaeróbios com crescimento aderido de biomassa, em um leito fixo, são os filtros anaeróbios (AF). Estes são caracterizados pela presença de um leito reacional empacotado estacionário, onde a biomassa permanece aderida na superfície do material suporte ou mantida entre os interstícios do leito. A massa de microrganismos aderida ou mantida entre os interstícios degrada o substrato presente na água residuária que permeia pelo leito. Embora a biomassa se desprenda esporadicamente do leito, o tempo médio de retenção celular no reator é usualmente maior do que 20 dias.

As primeiras investigações referentes a utilização de filtros anaeróbios datam do final de 1960, desde então sua aplicação tem crescido no tratamento de águas residuárias industriais e de esgoto sanitário. Estes reatores são usualmente operados com escoamento vertical, fluxo ascendente (YOUNG \& McCARTY, 1969) ou descendente (van DEN BERG \& LENTZ, 1979), sendo que os reatores de fluxo ascendente os mais comumente utilizados. Na configuração de fluxo ascendente, o afluente entra pelo base, ascende pelo reator através do leito reacional (material suporte) e é coletado no topo do reator deixando o sistema (Figura 3.7). 


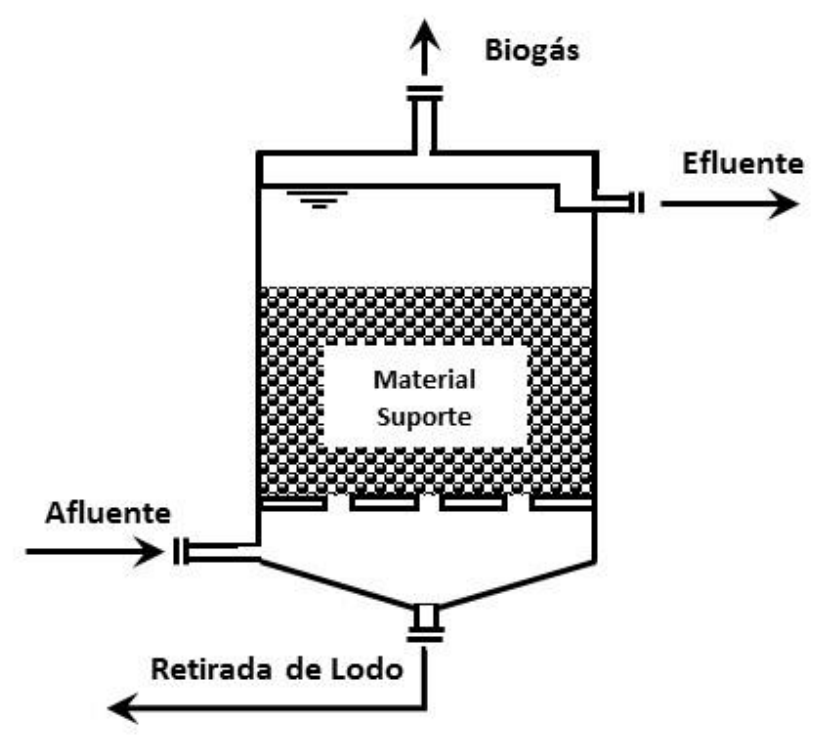

Figura 3.7 - Esquema representativo do filtro anaeróbio de fluxo ascendente.

Na configuração de fluxo descendente, o afluente é distribuído na parte superior do reator, acima do material suporte, sendo coletado pelo fundo do reator. Os filtros de fluxo descendente podem ter o leito reacional submersos ou não submersos. A prática de recirculação é mais comum neste configuração (Figura 3.8).

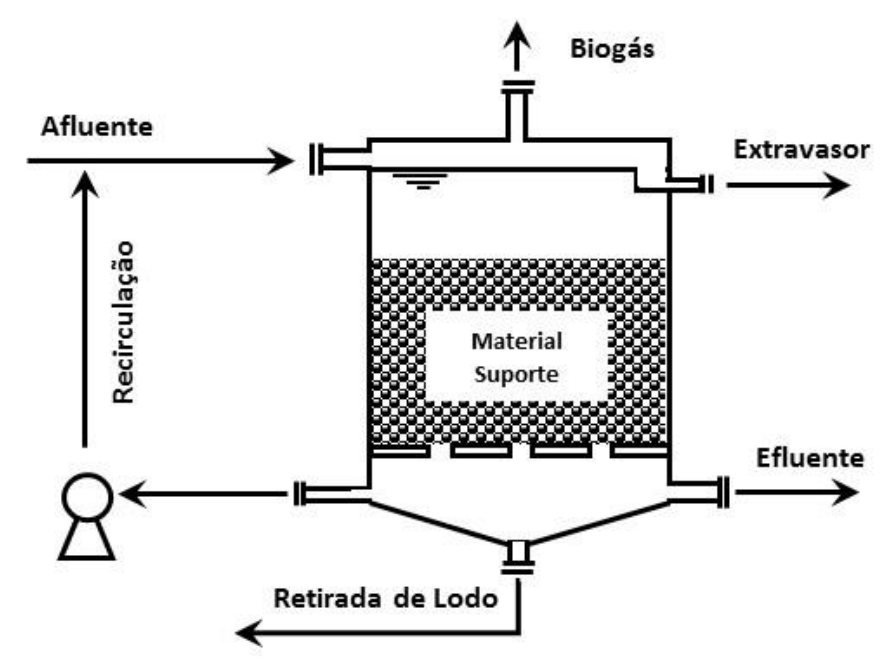

Figura 3.8 - Esquema representativo do filtro anaeróbio de fluxo descendente.

O tempo de retenção celular é muito elevado nestes reatores, devido a adesão da biomassa no material suporte, favorecendo um ótimo desempenho do sistema. A característica mais importante deste tipo de sistema de tratamento são o tempo de retenção celular e a concentração de biomassa ativa presente no leito reacional. O elevado tempo de retenção celular associado com o baixo tempo de detenção hidráulica proporciona, ao 
filtro anaeróbio, um alto potencial de aplicação no tratamento de águas residuárias com baixas concentrações de substratos, como os esgotos sanitários. Uma porção significativa da biomassa está na forma de flocos suspensos mantida entre os interstícios do leito, um fato que fez com que alguns pesquisadores afirmassem que a forma do material suporte (superfície de adesão) possui maior importância do que o material utilizado.

A principal desvantagem dos filtros anaeróbios de fluxo ascendente é o acúmulo de biomassa no fundo dos reatores, podendo levar ao entupimento ou a formação de curtos circuitos hidráulicos (zonas mortas). Neste sentido, filtros anaeróbios de fluxo descendente são mais indicados para o tratamento de águas residuárias contendo altas concentrações de sólidos em suspensão.

Com a aplicação do AF em grande escala, o entupimento e colmatação do leito representaram um grave problema, especialmente quando rochas eram utilizadas como meio suporte (YOUNG, 1991). Deste modo, muitos estudos foram realizados para superar esses problemas hidrodinâmicos, por meio da utilização de materiais suporte inertes com alta porosidade e alta área superficial específica. No entanto, a presença de zonas mortas e caminhos preferenciais, especialmente na parte inferior do filtro, não foram solucionadas (TILCHE \& VIEIRA, 1991).

Para Zaiat e colaboradores (1996), o desenvolvimento de biorreatores contendo células imobilizadas levou ao aumento do uso da tecnologia anaeróbia para o tratamento de águas residuárias. Por outro lado, os insucessos e as barreiras à aplicação dessa tecnologia em vários países, podem ser creditadas ao desenvolvimento e aumento de escala desses reatores com base e critérios puramente empíricos, uma vez que a abordagem "caixa preta" dificulta a otimização desses sistema. Deste modo, adoção de critérios fundamentais torna-se essencial para permitir a concepção de unidades heterogêneas com velocidades desejadas de degradação da matéria orgânica.

Neste direcionamento, as velocidades de transferência de massa são extremamente importantes em sistemas heterogêneos, uma vez que o substrato utilizado e os produtos gerados nos processos biológicos podem movimentar-se de uma fase para outra. Em tais sistemas, a transferência de massa e a quantidade relativa das várias fases desempenham um importante papel na determinação da velocidade global das reações (ATKINSON, 1974). Deste modo, tanto a transferência de massa quanto as velocidades das reações bioquímicas devem ser avaliadas para que a etapa mais lenta seja identificada, sendo que a limitação a transferência de massa torna-se importante para a obtenção de alto desempenho em sistemas contendo células imobilizadas. 
A resistência a transferência de massa na fase líquida (resistência externa) decresce à medida que a velocidade superficial $\left(\mathrm{v}_{\mathrm{s}}\right)$ aumenta, devido à redução da camada de líquido estagnada (camada limite). De acordo com Atkinson (1974), a velocidade global das reações é influenciada pela velocidade de escoamento do fluido, tornando-se essencialmente constante quando altas velocidades de escoamento são aplicadas. No entanto, isso só é verdade quando a transferência de massa externa é o fenômeno que limita o processo global.

A resistência a transferência de massa na fase sólida (resistência interna) é influenciada pelas dimensões e configuração espacial das partículas de biomassa, além das características do material suporte e da concentração da biomassa.

Neste contexto, Zaiat e colaboradores (2000) afirmam que o parâmetro operacional, dado pela velocidade superficial, e o parâmetro de projeto, dado pela dimensão do material suporte, estão intrinsicamente relacionados, afetando a velocidades global das reações e, consequentemente, o desempenho dos sistemas contendo células imobilizadas.

Elmitwalli e colaboradores (2000) operando um filtro anaeróbio contendo espuma de poliuretano reticulada como material suporte tratando esgoto sanitário, identificaram que a área superficial específica, a porosidade, a rugosidade do leito, o tamanho dos poros, e a orientação do material suporte no leito reacional possuem um papel importante no desempenho do reator.

Alta área superficial específica e porosidade, macro poros e superfícies rugosas do material suporte melhoraram o desempenho de filtros anaeróbios (van den BERG \& LENTZ, 1983; HUYSMAN et al., 1983; YOUNG \& DAHAB, 1983; YOUNG, 1991; KENNEDY \& DROSTE, 1991; IWAI \& KITAO, 1994).

Leitos reacionais contendo material suporte poroso e disposto de modo ordenado apresentaram melhores desempenhos quando comparados a leitos empacotados (material disposto de modo aleatório) não porosos (YOUNG \& DAHAB, 1983; HUYSMAN et al., 1983; ANDERSON et al., 1994).

Para Huysman e colaboradores (1983), espumas de poliuretano reticuladas apresentam-se como uma excelente matriz para a colonização da biomassa em filtros anaeróbios, possuindo alta área superficial específica, alcançando valores superiores a $2.400 \mathrm{~m}^{2} / \mathrm{m}^{3}$ e alta porosidade $(97 \%)$.

Tilche e Vieira (1991) operando um filtro anaeróbio contendo espuma de poliuretano como material suporte, observaram que o material suporte foi capaz de reter 
acima de $15 \mathrm{~kg} \mathrm{SV} . \mathrm{m}^{-3}$ de biomassa aderida.

Miyahara e Noike (1994) estudaram os efeitos na remoção de sólidos em suspensão (celulose) e na hidrólise desses sólidos, quando diferentes materiais suporte forma utilizados no filtro anaeróbio alimentado com água residuária sintética de baixa concentração (500 mg DQO.L ${ }^{-1}$ ). Os pesquisadores observaram que tanto a qualidade do efluente quanto a hidrólise da celulose foram notavelmente melhorados com a utilização do material suporte.

\subsubsection{Reator Anaeróbio Híbrido}

O reator anaeróbio híbrido (HAnR) foi desenvolvido por Guiot e colaboradores (1984), sendo constituído essencialmente de um escoamento ascendente do afluente por meio de um leito denso de lodo localizado na parte inferior e de um leito estacionário, contendo material suporte para a adesão celular, na parte superior do reator, combinando as vantagens dos reatores UASB e filtro anaeróbio, enquanto minimiza suas limitações (KENNEDY \& GUIOT, 1986).

A região contendo o material suporte, além de possuir a função física de retenção da biomassa, também contribui para a conversão da matéria orgânica aonde geralmente, nos reatores UASB clássicos, a biomassa ainda com alta atividade deixa o sistema (TILCHE \& VIEIRA, 1991).

Como apresentado na figura 3.9, o afluente entra pela parte inferior e o efluente deixa o reator por meio de um compartimento interno localizado na parte superior do reator. O separador gás-líquido-sólido (separador trifásico), localiza-se em algumas configurações abaixo do leito fixo enquanto que para outras configurações, localiza-se acima do leito fixo. Devido a imobilização da biomassa, o tempo médio de retenção de sólidos no reator permanece suficientemente alto favorecendo o crescimento e a formação de uma densa massa microbiana metanogênica, mesmo aplicando-se baixos tempos de detenção hidráulica. 


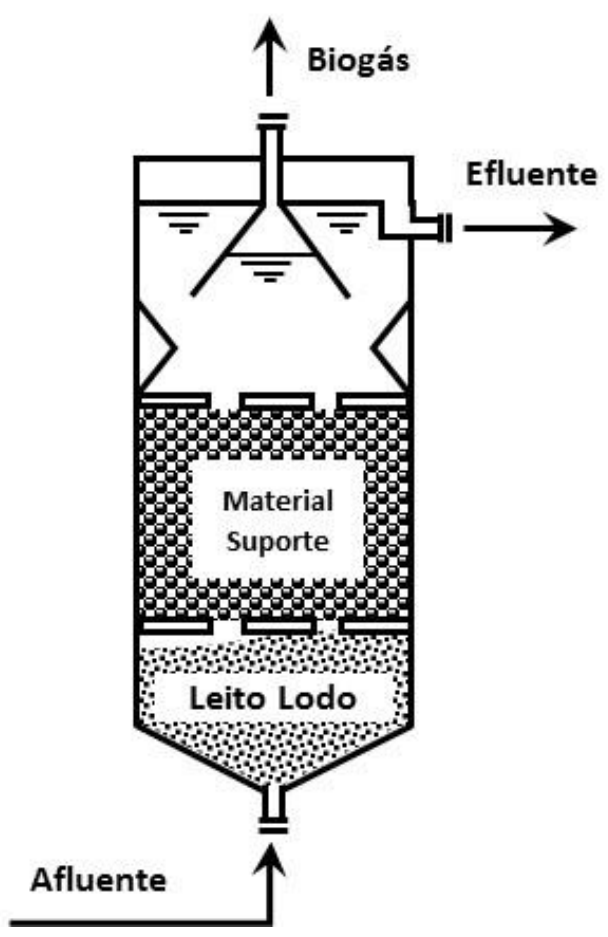

Figura 3.9 - Esquema representativo do reator anaeróbio híbrido.

Kennedy e Guiot (1986) comparando o desempenho de um reator UASB com um HAnR tratando água residuária sintética, obtiveram um melhor desempenho na remoção de DQO no HAnR (96\%) quando comparado ao reator UASB (83\%). Para as mesmas condições de carga orgânica, van der Merwe \& Britze (1993) e Cordoba et al. (1995) observaram um melhor desempenho do HAnR quando comparado a um filtro anaeróbio.

De acordo com Iwai e Kitao (1994), o biofilme presente no leito fixo proporciona as seguintes vantagens: (i) start-up em menor tempo; (ii) maior capacidade de remoção compostos de difícil decomposição; (iii) maior tolerância à choques de temperatura e carga; e (iv) ganho de eficiência para águas residuárias com baixa concentração de substrato.

Para Huysman et al. (1983) e Anderson et al. (1994), o uso de materiais suporte porosos que possuam alta área superficial e proporcionem uma elevada porosidade do leito reacional, melhoram o desempenho de reatores anaeróbios quando comparados com materiais suporte não porosos. Huysman e colaboradores (1983) complementam dizendo que meios porosos representam uma excelente matriz para a colonização microbiana. Posteriormente, seus resultados foram confirmados por Fynn e Whitmore (1984), Calzada et al. (1984), Derycke e Verstraete (1986), Gijzen et al. (1988) e Zaiat et al. (1996).

Espumas de poliuretano podem atingir áreas superficiais específicas da ordem de 
$2.400 \mathrm{~m}^{2} \cdot \mathrm{m}^{-3}$ e porosidade de $97 \%$, possuindo portanto, alta capacidade de retenção e adesão de biomassa, da ordem de $15 \mathrm{~kg} \mathrm{SV} . \mathrm{m}^{-3}$ (van ROMPU et al., 1990; TILCHE \& VIEIRA, 1991). Além disso, Zaiat e colaboradores (1996) constataram que a espuma de poliuretano reticulada possui a capacidade de retenção de biomassa mesmo submetido a elevadas velocidades ascensionais, onde apenas $9 \%$ dos sólidos em suspensão voláteis foram lavados do sistema para a velocidade superficial aplicada de $80 \mathrm{~m} \cdot \mathrm{h}^{-1}$.

Elmitwalli e colaboradores (2000) tratando esgoto sanitário pré-tratado à temperatura de $13^{\circ} \mathrm{C}$ em um reator UASB e dois HAnR, contendo espuma de poliuretano como material suporte, obtiveram um ganho de $4 \%$ na eficiência média de remoção de DQO total no HAnR em comparação a obtida no reator UASB (60\%DQO).

Elmitwalli e colaboradores (2000) também afirmam que o material suporte, presente na parte superior do HAnR, melhora a remoção das partículas coloidais tanto por filtração quanto por floculação. Além disso, os pesquisadores observaram que os microrganismos anaeróbios possuem a característica de agregarem-se formando flocos ou grânulos, produzindo substâncias poliméricas extracelulares (polissacarídeos, polipeptídios e/ou peptidoglicanos) para tal finalidade, as quais auxiliam também na biofloculação e bioadsorção das partículas pelo mecanismo de pontes (DUGAN, 1987; MORGAN et al., 1990; POXON \& DARBY, 1997).

\subsection{BIOMASSA IMOBILIZADA EM SUPORTE INERTE}

Uma alternativa que vem sendo estudada para aprimorar a configuração dos reatores é a utilização de biomassa imobilizada em suporte inerte. Neste caso ocorre a formação de biofilme aderido à superfície do suporte, com predomínio deste sobre culturas livres em suspensão, havendo a criação de microambientes especiais pela interação entre as espécies, favorecendo o conjunto como um todo e garantindo grande estabilidade das colônias. Além disso, a utilização de suportes inertes assegura a retenção da biomassa no reator e propicia a operação com tempo de retenção celular muito elevado, aumentando a estabilidade do reator, inclusive sob condições de sobrecarga e na presença de substâncias tóxicas (SPEECE, 1996).

A possibilidade de maior equilíbrio entre os microrganismos anaeróbios pela conformação espacial mais favorável e diminuição das distâncias entre organismos ou micro-colônias, a eliminação das incertezas quanto à granulação da biomassa e a 
possibilidade de utilização do meio suporte como fator de seleção ou enriquecimento de alguns organismos desejáveis e eliminação de outros indesejáveis são vantagens adicionais (ZAIAT, 2003).

No entanto, a utilização de um suporte para imobilização da biomassa adiciona algumas complicações à análise de reatores anaeróbios. Além das velocidades de consumo de substrato, geração de intermediários e produtos finais e de crescimento microbiano, devem também ser consideradas na análise destes reatores as velocidades de transferência de massa do meio líquido até os organismos na superfície e no interior do biofilme (ZAIAT, 2003). Deste modo, a eficiência de reatores contendo células imobilizadas também está diretamente relacionada com os fluxos de massa entre as fases líquida e sólida, os quais podem ser limitantes do processo de conversão e causar considerável decréscimo da velocidade global das reações (ARAUJO JUNIOR, 2006).

Neste sentido, a escolha do material adequado a ser utilizado como suporte é de fundamental importância para a formação do biofilme e retenção da biomassa no interior do reator. A aderência depende das propriedades físico-químicas do suporte sendo que, de acordo com Huysman et al. (1983), as superfícies porosas e rugosas são mais propícias do que as superfícies lisas e, ainda, o tamanho e o número de poros também influenciará no resultado final. As características da água residuária devem ser consideradas, uma vez que poderá interagir com o suporte, além de interferir diretamente na adesão microbiana. Outro aspecto que deve ser considerado é que a condição hidrodinâmica do sistema deve propiciar a manutenção do biofilme, pois em situações hidrodinâmicas críticas o biofilme pode se desprender do suporte e consequentemente ser arrastado do reator (ALVES et al., 1999; HUYSMAN et al., 1983; GIJZEN et al., 1988; WIRTZ \& DAGUE, 1997; VARESCHE et al., 1997; RATUSZNEI et al., 2000).

\subsection{CONSIDERAÇÕES FINAIS}

Apesar do reconhecido sucesso do reator UASB como a unidade anaeróbia mais eficaz (no que tange o custo-benefício) e utilizada para o tratamento de esgotos sanitários bruto, algumas limitações desta tecnologia são evidentes. O baixo grau de mistura, a hidrólise como etapa limitante do processo, a formação de escuma dentro do separador trifásico, as altas perdas de sólidos suspensão voláteis (SSV) no efluente e a baixa produção de biogás são questões sérias que merecem a devida atenção para a melhoria do 
projeto do reator, assim, presumivelmente, permitindo melhora em seu desempenho. No intuito de transpor estas limitações algumas modalidades de reatores anaeróbios de alta taxa foram desenvolvidos, algumas adaptações no desenho foram propostas e algumas alterações na planta do sistema foram empregadas (GUIOT et al., 1984; KALOGO \& VERSTRAETE, 1999; ELMITWALLI et al., 2000; MAHMOUD et al., 2003; FORESTI et al., 2006; van HAANDEL et al., 2006).

Entre estas, as alterações de forma tiveram menor ênfase, dentro das pesquisas e aplicações dos reatores UASB tratando esgotos sanitários (FORESTI et al., 2006). Deste modo, não há uma concepção modificada de reator UASB consagrada, especialmente desenvolvida para tratar esgotos sanitários e apenas algumas poucas adaptações na concepção original foram propostas. Neste caso, é ainda a versão original do reator UASB que atualmente apresenta maior sucesso no tratamento de esgotos sanitários (FORESTI et al., 2006; AIYUK et al., 2006).

Neste contexto, as pesquisas sobre novas configurações de reatores anaeróbios têm se intensificado nos últimos anos, indicando não somente a necessidade de se buscar alternativas aos sistemas já estabelecidos, mas, principalmente, de se desenvolver configurações otimizadas, que forneçam o máximo de desempenho, segurança operacional e que apresentem mínimo custo. Desta forma, os reatores anaeróbios estão em constante evolução de modo a tornar a biotecnologia anaeróbia viável para aplicação ao tratamento de esgotos sanitários.

A partir da constatação da importância do biofilme, as novas concepções de reatores anaeróbios de alta taxa possuem como característica comum, a utilização de um meio suporte inerte que permite o crescimento e a retenção da biomassa no seu interior. Esta característica fundamentou a concepção dos filtros anaeróbios na década de sessenta e, posteriormente, dos reatores de leito fluidificado e expandido e dos reatores híbridos (leito fixo e manta de lodo).

Deste modo, no entendimento deste autor, o desenvolvimento de uma nova configuração de reator anaeróbio de alta taxa aplicado ao tratamento de esgotos sanitários municipais que possa transpor as limitações apresentadas pelo reator UASB, aproveitando-se dos benefícios dos sistemas de células auto-imobilizadas e imobilizadas, é de grande interesse às empresas privadas e públicas que respondem pelo saneamento básico no Brasil. 


\section{Material e Métodos}

\subsection{DESCRIÇÃO GERAL DOS EXPERIMENTOS}

O projeto de pesquisa objetivou estudar o comportamento de um reator anaeróbio híbrido (leito fixo e manta de lodo), em escala piloto, contendo material suporte para a imobilização celular (Biobob®) no tratamento de esgoto sanitário proveniente do tratamento preliminar da estação de tratamento de esgoto Itaipu (ETE Itaipu), localizada na cidade de Niterói, estado do Rio de Janeiro, sob concessão da Concessionária Águas de Niterói S/A pertencente ao grupo Águas do Brasil.

Para tanto, a fase experimental foi dividida em seis etapas principais e mais três etapas adicionais, sendo que, para estas últimas, repetiram-se as mesmas condições operacionais da quarta, sexta e segunda etapa, respectivamente. Na primeira etapa, com a finalidade de utilizar os resultados como parâmetro comparativo para as etapas subsequentes, a planta piloto foi operada como um reator UASB na condição equivalente

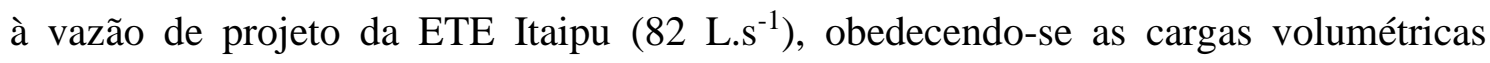
aplicadas e taxas de aplicação superficial, ou seja, vazão afluente igual a $1,4 \mathrm{~m}^{3} \cdot \mathrm{h}^{-1} \mathrm{e}$ sem a adição de material suporte para a imobilização celular. Posteriormente, na segunda etapa, objetivando-se avaliar o desempenho do reator anaeróbio quanto a remoção de matéria orgânica e retenção de sólidos suspensos, foi adicionado um volume igual a 5,0 $\mathrm{m}^{3}$ (aproximadamente $40 \%$ do volume útil do reator) do material suporte Biobob® no leito reacional (leito empacotado), mantendo-se a vazão afluente igual a $1,4 \mathrm{~m}^{3} \cdot \mathrm{h}^{-1}$. Nas etapas subsequentes, terceira a sexta, a vazão afluente do reator anaeróbio, contendo $5 \mathrm{~m}^{3}$ do material suporte Biobob ${ }^{\circledR}$, foi aumentada gradativamente (incremento de $0,36 \mathrm{~m}^{3} \cdot \mathrm{h}^{-1}$ por etapa) até que se alcançou a vazão afluente de $2,8 \mathrm{~m}^{3} \cdot \mathrm{h}^{-1}$ (valor equivalente a $200 \%$ 
da vazão de projeto da ETE Itaipu), objetivando-se avaliar o desempenho do reator quanto a remoção de matéria orgânica e retenção de sólidos em suspensão mediante as altas cargas volumétricas e altas velocidades ascensionais aplicadas.

Ao final dos experimentos, a biomassa aderida ao material suporte disposto ao longo do reator anaeróbio híbrido, bem como a biomassa presente na manta de lobo foram quantificadas. Essas amostras de biomassa representavam apenas a última etapa de operação do reator, considerada a etapa mais importante dos experimentos.

\subsection{REATOR EM ESCALA PILOTO}

A investigação experimental foi realizada nas dependências da ETE Itaipu, a qual, implantada em março de 2005, foi projetada para atender aos padrões de lançamento exigidos pelas legislações federal e regional vigentes quanto à remoção de matéria orgânica, sólidos em suspensão, nitrogênio e fósforo, sendo constituída por um sistema de tratamento preliminar (gradeamento e desarenação), por três reatores em série: (i) reator anaeróbio de manta de lodo e escoamento ascendente (UASB); (ii) reator anóxico; e (iii) reator aeróbio com biodisco seguido de um decantador secundário; por fim, por um decantador terciário. A ETE Itaipu recebe a contribuição dos sistemas de esgotamento sanitário dos bairros Itaipu, Itacoatiara e Engenho do Mato, atendendo a uma população aproximada de 58.000 habitantes, correspondendo a uma vazão afluente igual a 82 L.s ${ }^{-1}$. A foto aérea e o fluxograma simplificado da ETE Itaipu são apresentados na Figura 4.1 e Figura 4.2, respectivamente.

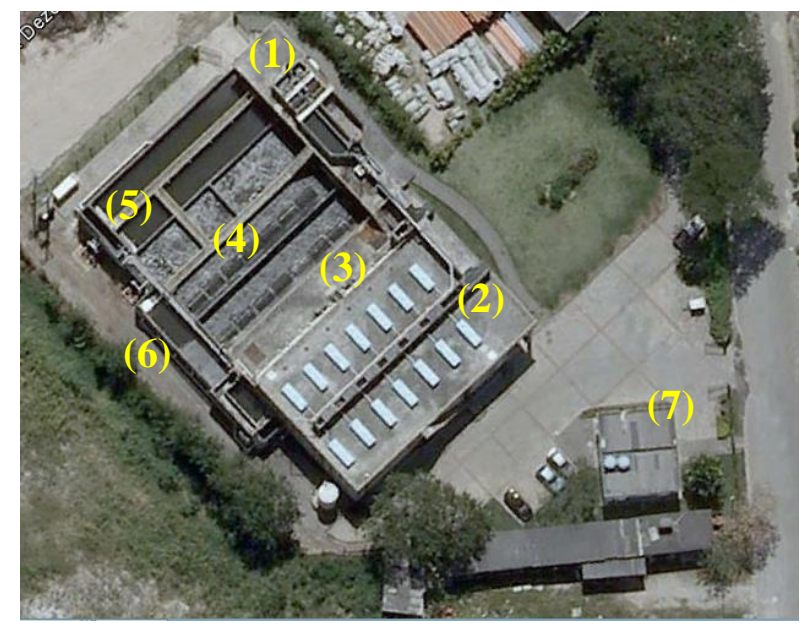

Figura 4.1 - Foto aérea da ETE Itaipu, Niterói, RJ: (1) tratamento preliminar; (2) reator

UASB; (3) reator anóxico; (4) reatores aeróbios com biodisco; (5) decantador secundário; (6) decantador terciário; e (7) laboratório (Fonte: Google Earth, 2011). 


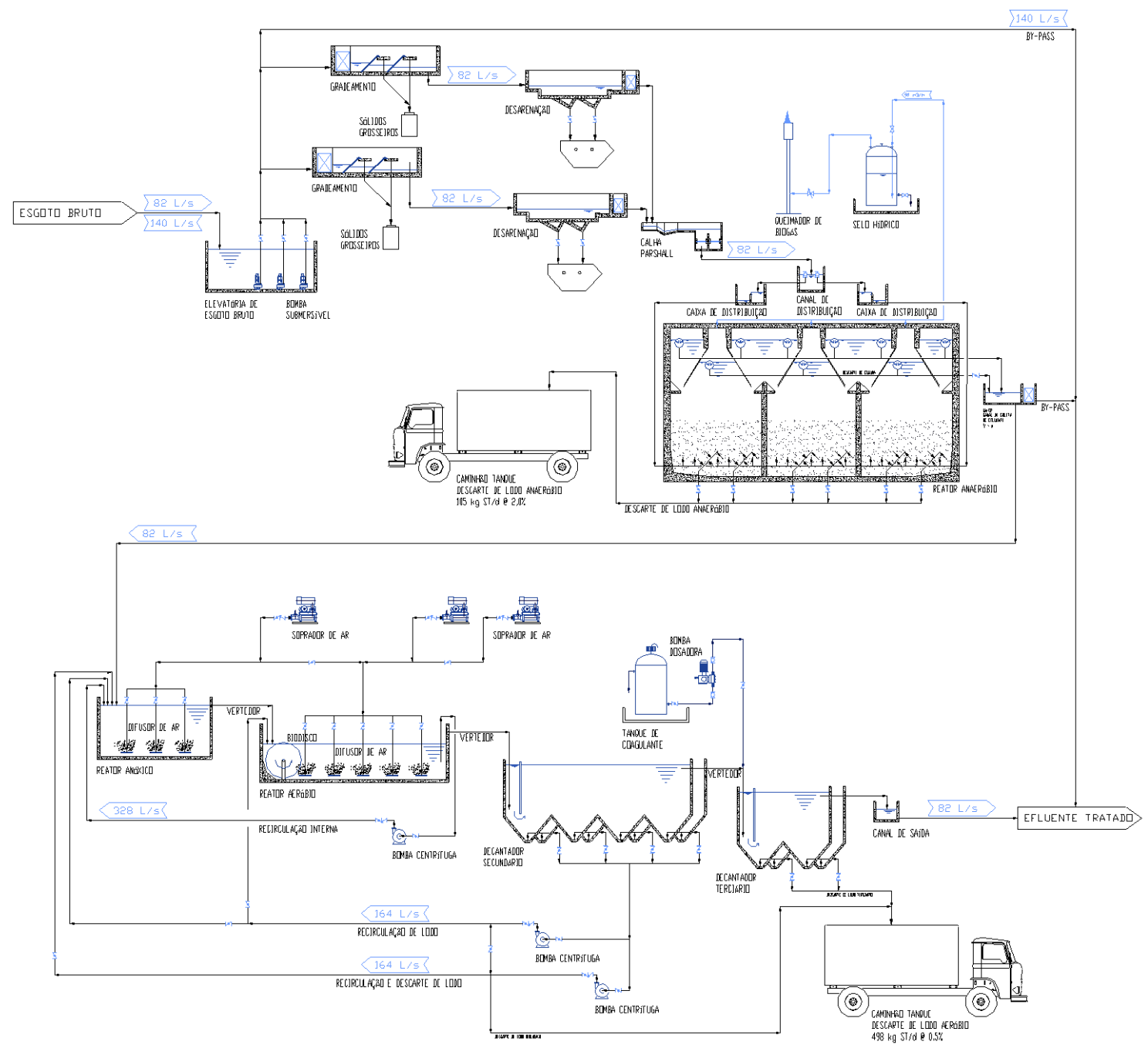

Figura 4.2 - Fluxograma simplificado da ETE Itaipu, Niterói, RJ.

Objetivando estudar uma nova concepção de reator anaeróbio para o tratamento de esgotos sanitários, bem como utilizar os resultados deste trabalho de pesquisa para a melhoria e ampliação, não somente da ETE Itaipu, mas também de outras estações já existentes contendo reatores UASB, a planta piloto foi projetada para reproduzir em escala reduzida (200 vezes menor) a estação real, obedecendo às mesmas cargas volumétricas aplicadas e taxas de aplicação superficial. Para tanto, em termos gerais a estação piloto de tratamento foi constituída por um reator anaeróbio de volume útil igual a 12,5 $\mathrm{m}^{3}$ e um selo hídrico de $0,3 \mathrm{~m}^{3}$ de volume útil, por um reator anóxico de volume útil igual a $2,3 \mathrm{~m}^{3}$, por um reator aeróbio de volume útil igual a $6,3 \mathrm{~m}^{3}$ e por fim, por um decantador secundário de alta taxa de área superficial igual a $1,1 \mathrm{~m}^{2}$ (lamelas modelo TUBEdek FS41.84, fornecidas pela empresa GEA Sistemas de Resfriamento Ltda). Embora a planta piloto tenha sido constituída pelos processos unitários citados acima, os estudos restringiram-se somente ao reator anaeróbio. Todos os reatores e o decantador 
secundário foram confeccionados em plástico reforçado com fibra de vidro (PRFV).

As fotos da instalação experimental são apresentadas na Figura 4.3 e o fluxograma de processo do reator anaeróbio piloto é mostrado na Figura 4.4.

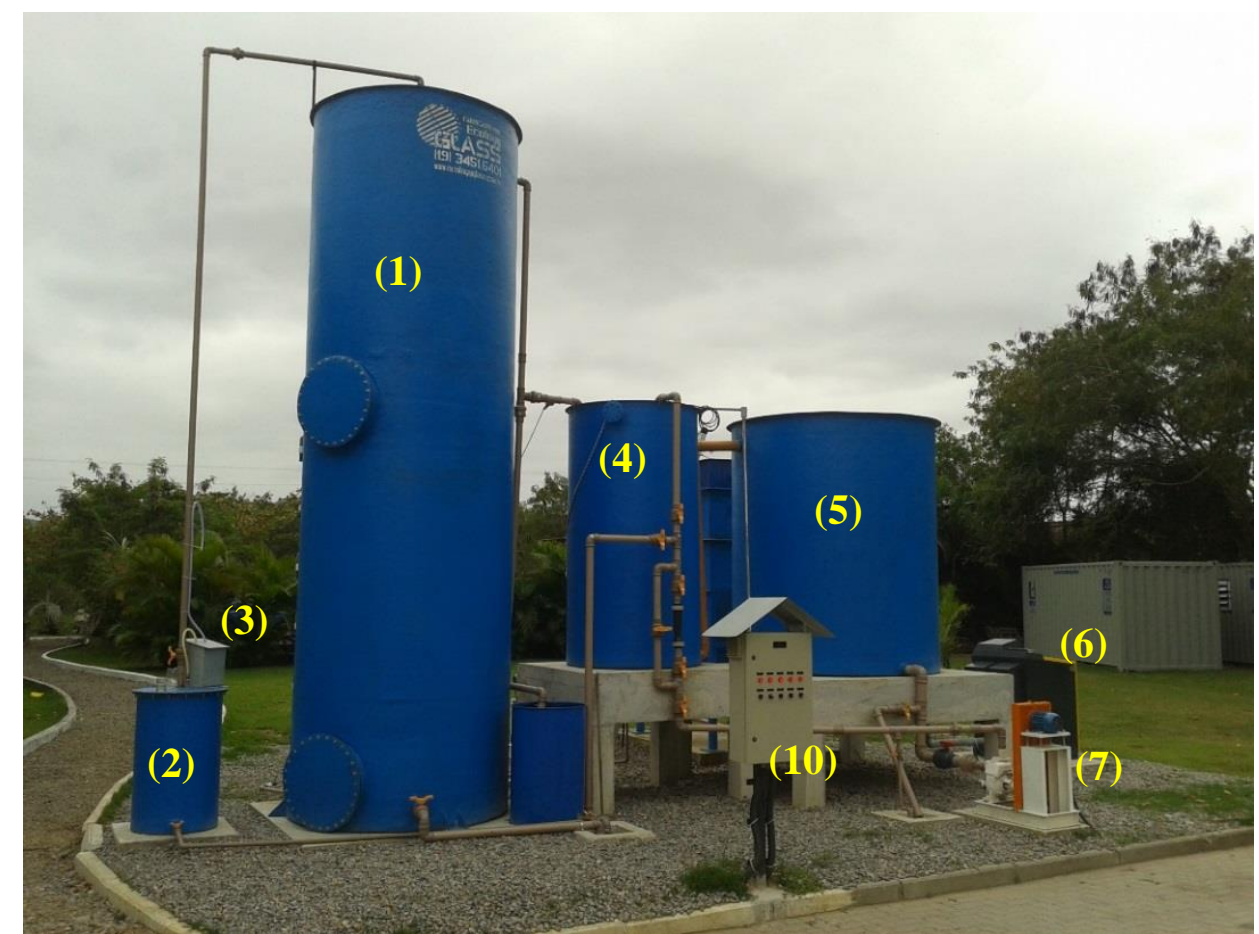

(a)

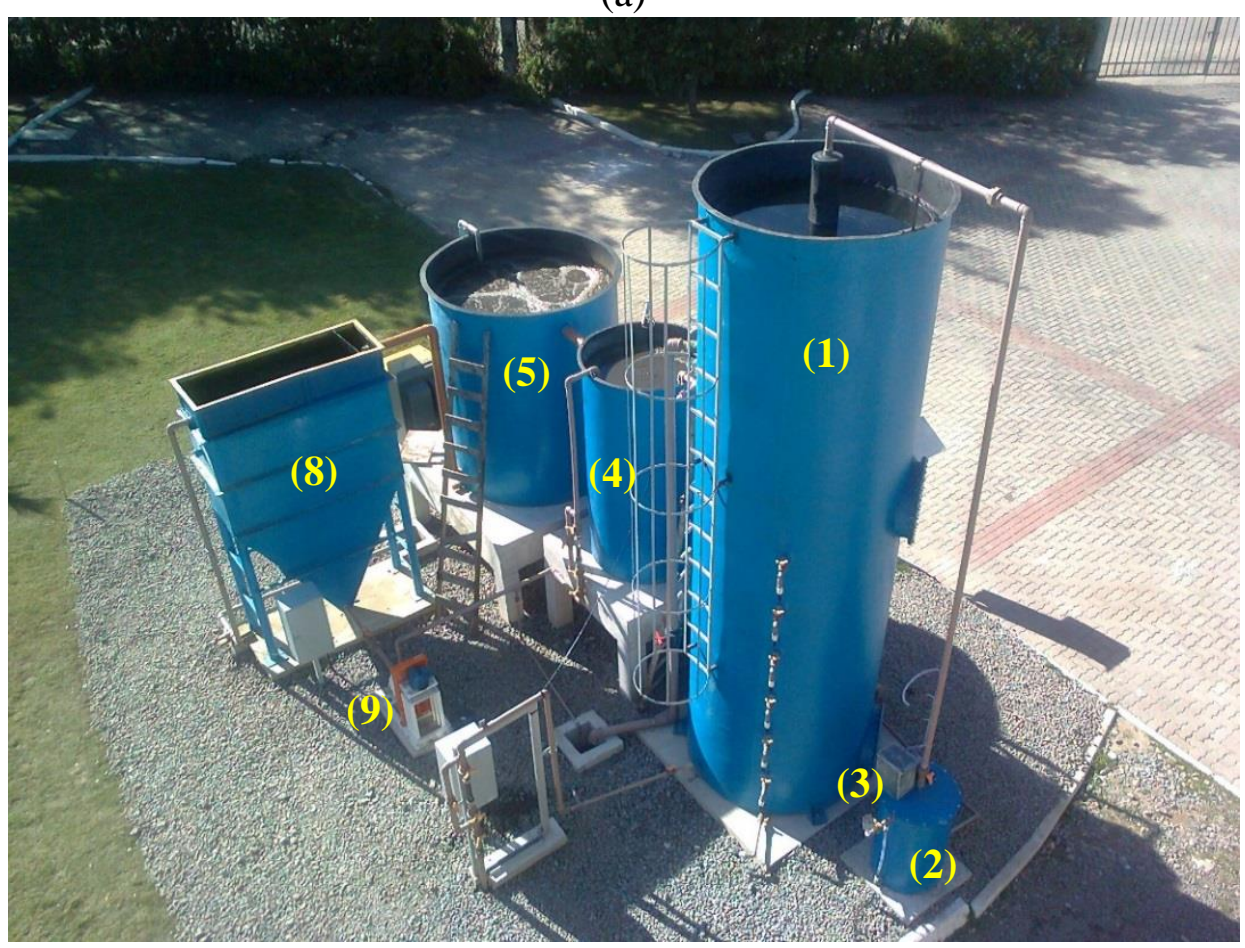

(b)

Figura 4.3 - Fotos da instalação experimental: (a) vista frontal; e (b) vista oposta: (1) reator anaeróbio, (2) selo hídrico, (3) medidor de biogás, (4) reator anóxico, (5) reator aeróbio, (6) soprador de ar, (7) bomba de recirculação (aeróbio-anóxico), (8) decantador secundário, (9) bomba de recirculação e descarte de lodo e (10) painel elétrico. 


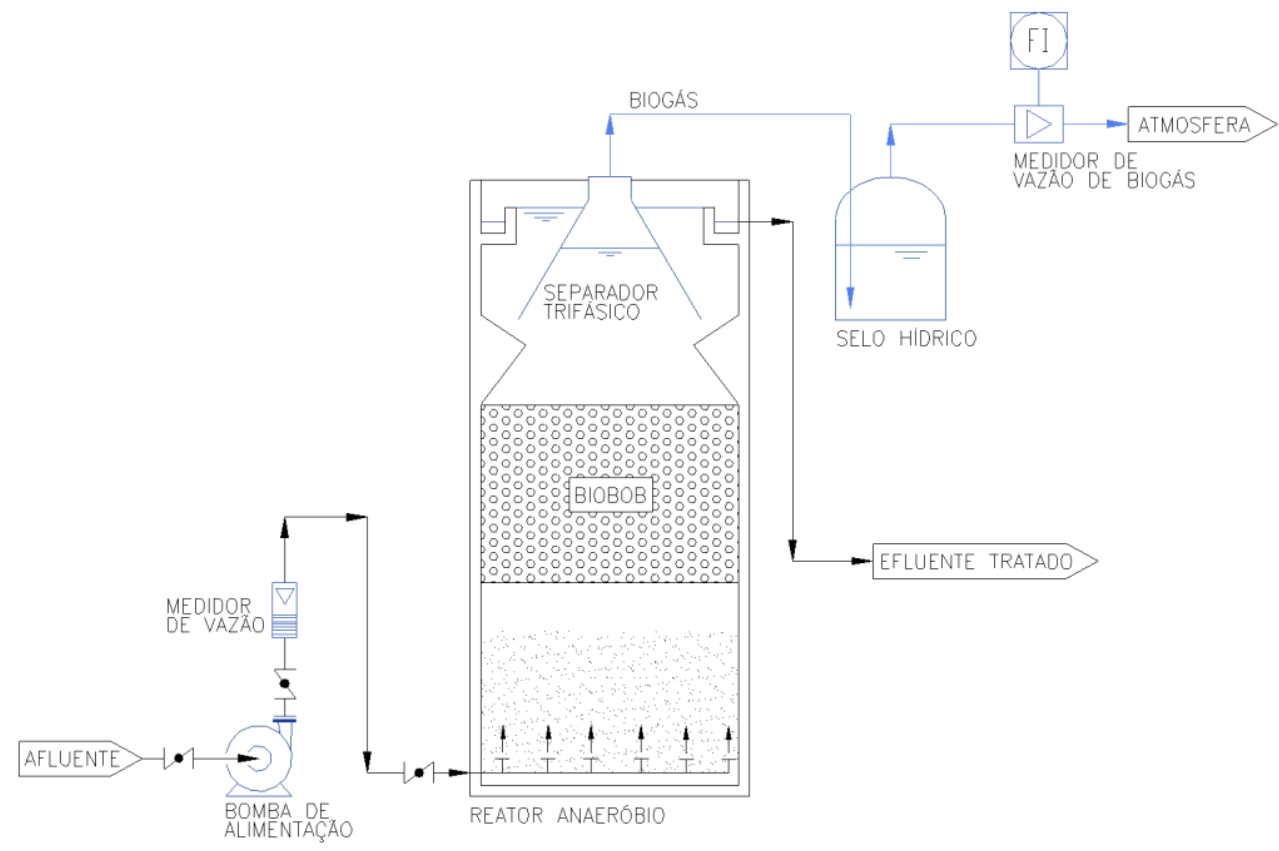

Figura 4.4 - Fluxograma de processo do reator anaeróbio piloto.

Em termos específicos, o reator anaeróbio de $12,5 \mathrm{~m}^{3}$ de volume total, com geometria cilíndrica de $1,7 \mathrm{~m}$ de diâmetro interno, altura útil de $5,5 \mathrm{~m}$, foi constituído por seis compartimentos, a saber: (i) alimentação; (ii) leito de lodo; (iii) leito de Biobob®; (iv) separação sólido-líquido-gás; (v) selo hídrico; e (vi) saída de efluente.

O compartimento de alimentação de $0,18 \mathrm{~m}$ de altura, foi constituído por um tubo central em PVC de 1", sendo conectado a este, cinco ramais de distribuição em PVC de $3 / 4$ ", com ejetores de $1 / 2$ " em PVC instalados nas extremidades de cada ramal, o qual transporta o esgoto bruto afluente ao interior do reator anaeróbio distribuindo-o uniformemente. Em uma extremidade desta tubulação central estão acoplados um registro do tipo globo de 1", a este, um barrilete contendo um medidor de vazão do tipo rotâmetro com faixa de vazão de 0,7 a 7,0 $\mathrm{m}^{3} \cdot \mathrm{h}^{-1} \mathrm{e}$, a este, uma bomba centrífuga submersível de rotor semiaberto FAMAC modelo FBS JAC, com capacidade de recalque em uma faixa de vazão de 0 a $9,7 \mathrm{~m}^{3} \cdot \mathrm{h}^{-1}$. Na outra extremidade desta tubulação central foi acoplado um registro do tipo globo de 1" para eventual descarga de fundo.

No compartimento do leito de lodo de $0,83 \mathrm{~m}$ de altura, localiza-se uma boca de visita de 0,60 $\mathrm{m}$ de diâmetro, instalada na parede do reator anaeróbio a 0,19 $\mathrm{m}$ de altura em relação à base, proporcionando o acesso aos ramais de alimentação bem como a estrutura inferior de sustentação do leito de Biobob®.

O leito de Biobob® foi construído com 2,20 m de altura útil e 2,84 m de altura total. Junto à parede e ao longo de todo o perímetro do reator foram soldadas a 0,84 m e 
a 3,68 m de altura em relação a base do reator, uma cantoneira inferior e uma cantoneira superior, respectivamente. Confeccionadas em PRFV ambas as cantoneiras possuíam 8 $\mathrm{mm}$ de espessura e $20 \mathrm{~cm}$ de largura e, fixadas sobre estas, telas do tipo artística de $1 \frac{1}{2}$ " de abertura e fio $\mathrm{N}^{\mathrm{o}} 12$, confeccionadas em aço galvanizado revestido com tinta epóxi, para suportar os esforços de empuxo $(2,3 \mathrm{kN})$ e peso $(16,4 \mathrm{kN})$ proporcionados pelo material suporte Biobob®. Neste compartimento, localiza-se também uma segunda boca de visita de $0,60 \mathrm{~m}$ de diâmetro instalada na parede do reator a 3,03 $\mathrm{m}$ de altura em relação à base, proporcionando o acesso a estrutura superior de sustentação do leito bem como possibilitando a adição e remoção do material suporte.

No compartimento de separação sólido-líquido-gás de 1,67 m de altura, localizase um defletor de $0,25 \mathrm{~m}$ de largura, soldado na parede do reator ao longo de todo o seu perímetro, a uma altura de 3,69 m em relação à base. Também neste compartimento localiza-se um separador trifásico de 1,20 m de altura útil, com geometria cônica de 1,4 $\mathrm{m}$ de diâmetro e inclinação de $63^{\circ}$. Na extremidade superior do separador trifásico foi acoplada uma tubulação afogada de $1 \frac{1}{2} 2$ " de PVC, e a esta, um selo hídrico de 1,00 m de altura total, com geometria cilíndrica de $0,58 \mathrm{~m}$ de diâmetro interno. Acoplado à tampa do selo hídrico, encontra-se uma tubulação de 1 1/2" de PVC, e a esta, um totalizador volumétrico de biogás LAO modelo G06, com capacidade de leitura em uma faixa de vazão igual a $0,016 \mathrm{~m}^{3} \cdot \mathrm{h}^{-1}$ a $1,25 \mathrm{~m}^{3} \cdot \mathrm{h}^{-1}$, responsável pela quantificação do biogás gerado no reator anaeróbio. Para a remoção de escuma, na extremidade inferior do separador trifásico, a $0,10 \mathrm{~m}$ de altura em relação a base, foi acoplada uma tubulação de $2 \frac{1}{2} 2$ " em PVC e, a esta, uma válvula do tipo globo de $2 \frac{1}{2}$ " de PVC.

Com altura de $0,15 \mathrm{~m}$, a câmara de saída continha uma calha tipo vertedor triangular instalada ao longo de todo o perímetro do reator que coletava o efluente de modo uniforme do reator anaeróbio e direcionava-o por meio de uma tubulação de 2" em PVC ao reator anóxico.

Foram previstas sete tomadas de amostras instaladas na parede do reator anaeróbio espaçadas a cada $0,50 \mathrm{~m}$ de altura a partir da base, compostas por válvulas do tipo globo de 1" de PVC acopladas a tubulações de 1" de PVC.

Durante todo o experimento, o reator foi operado em condições de temperatura ambiente média de $26 \pm 2^{\circ} \mathrm{C}$.

As fotos da etapa de fabricação e montagem são apresentadas na Figura 4.5 e o desenho dimensional do reator anaeróbio é apresentado na Figura 4.6. 


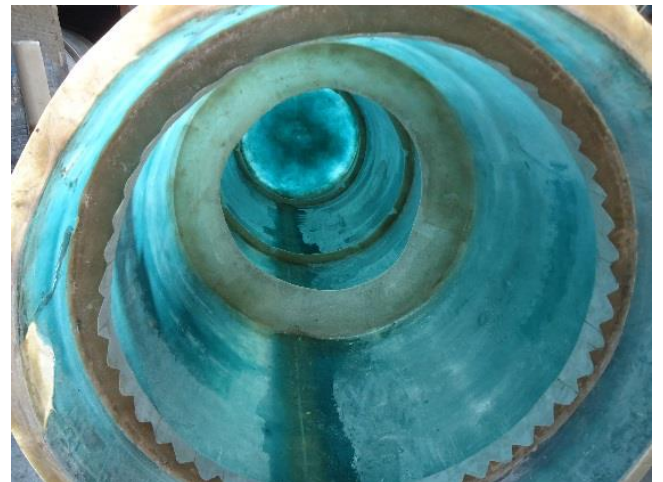

(a)

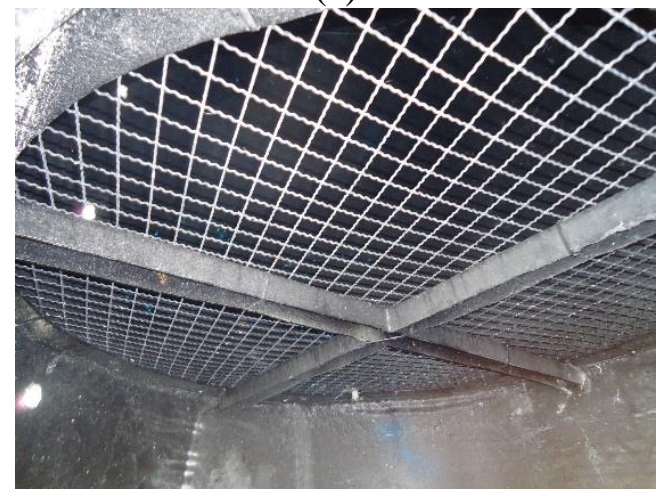

(c)

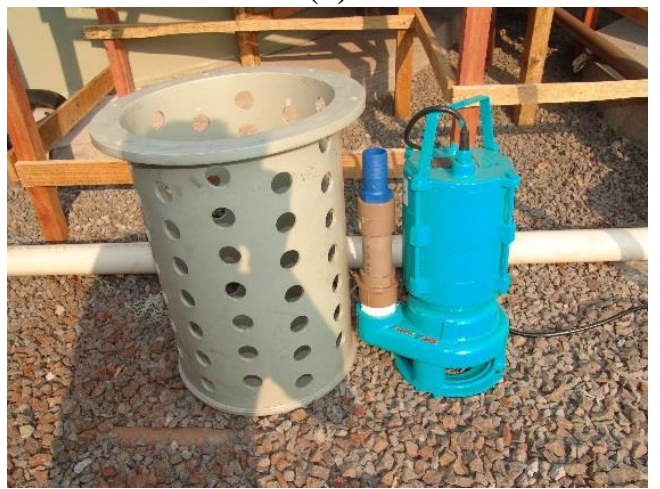

(e)

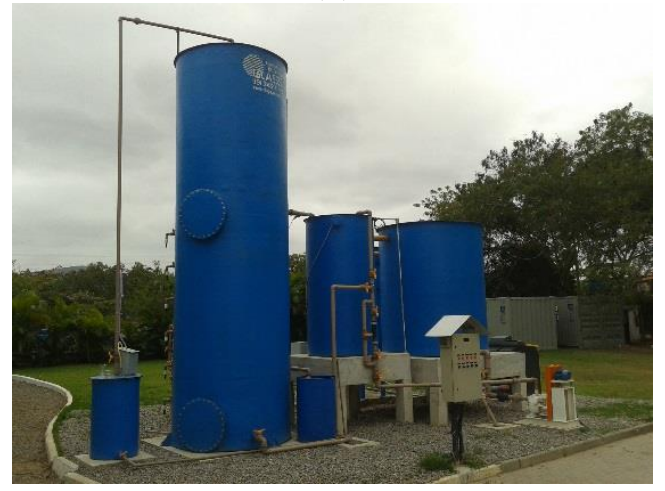

(g)

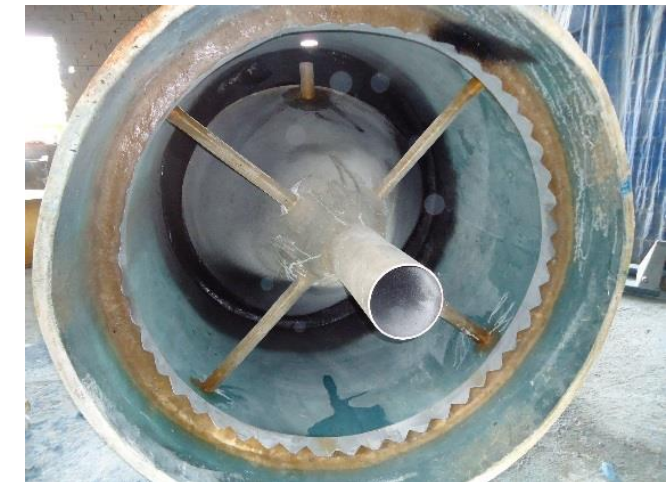

(b)

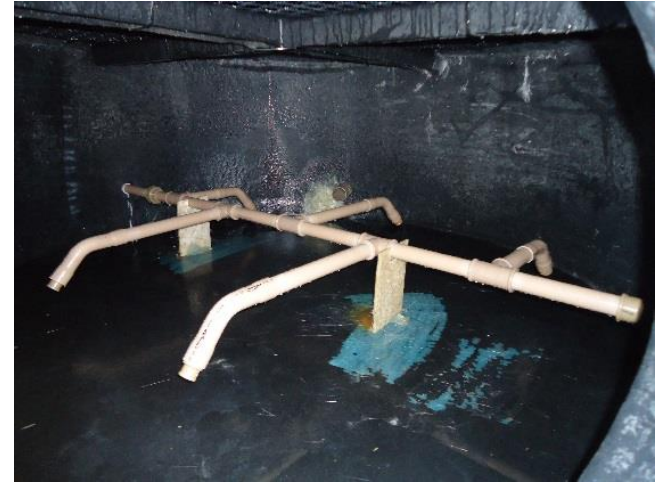

(d)

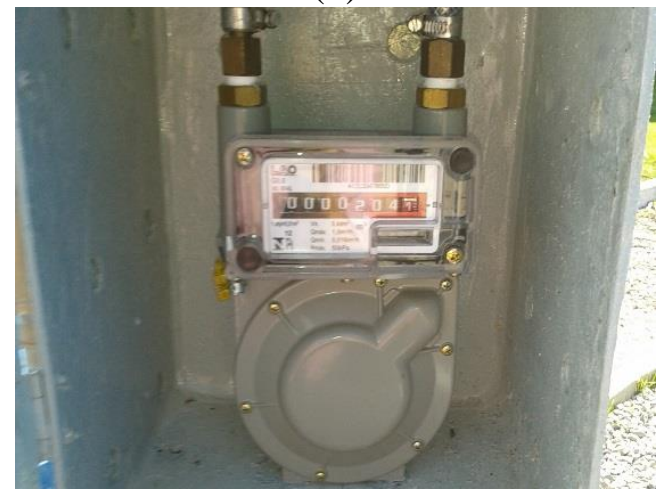

(f)

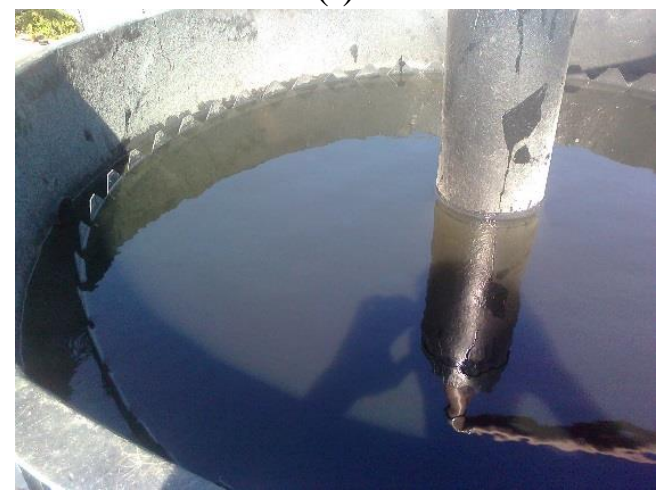

(h)

Figura 4.5 - Fotos da fabricação e montagem do reator piloto: (a) fabricação das estruturas de sustentação do leito, defletor e calha de saída; (b) instalação do separador trifásico; (c) instalação da tela de sustentação do leito; (d) montagem do ramal de alimentação; (e) bomba de alimentação e cesto de proteção; (f) medidor de biogás; (g) instalação e montagem eletromecânica concluídas; e (h) reator piloto em operação. 


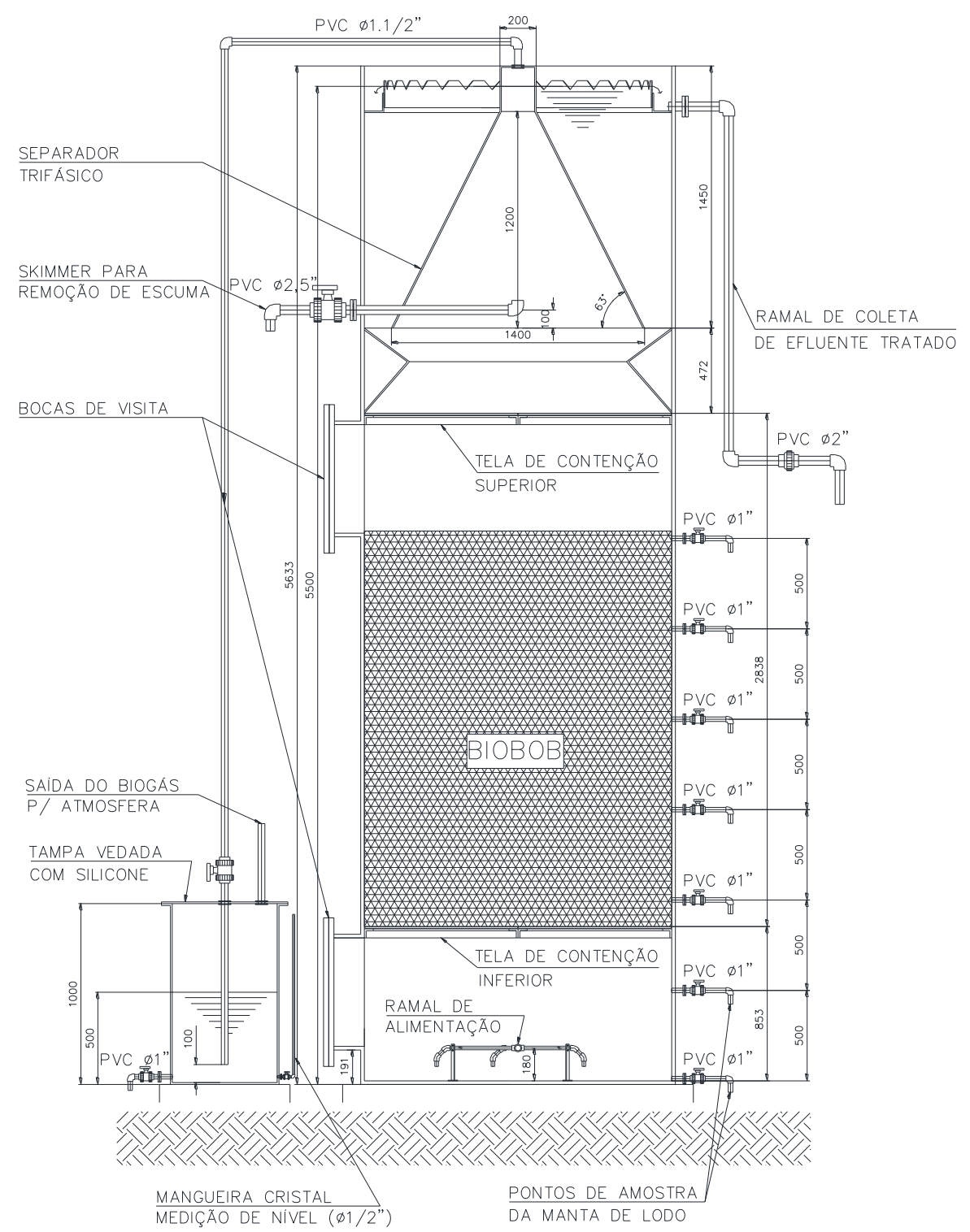

(a)

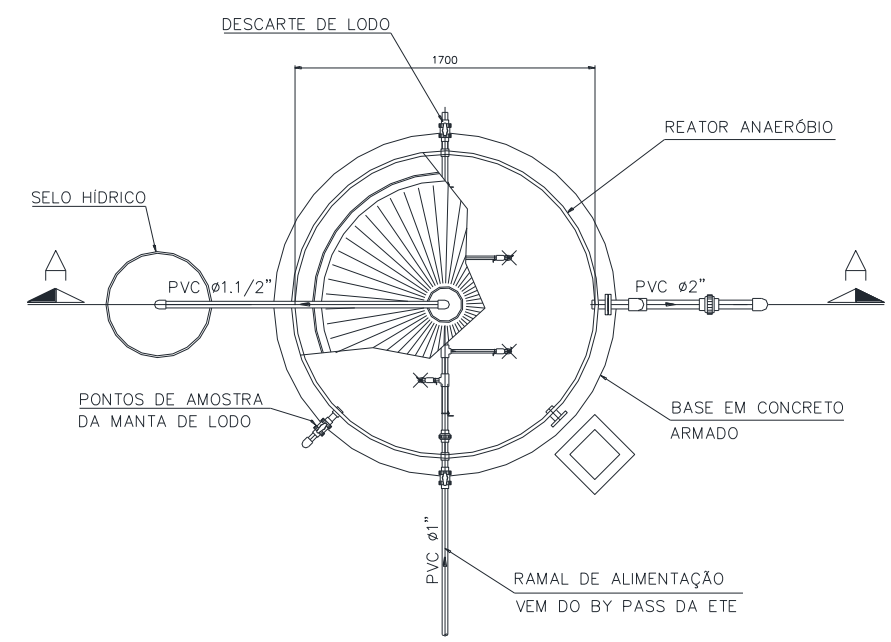

(b)

Figura 4.6 - Desenho dimensional do reator anaeróbio (medidas em milímetros): (a) vista longitudinal (Corte AA) e (b) vista em planta. 


\subsection{SUPORTES PARA IMOBILIZAÇÃO DA BIOMASSA}

Como suporte de imobilização da biomassa anaeróbia foi utilizado o produto comercial Biobob®, desenvolvido pela empresa Bio Proj Tecnologia Ambiental Ltda.

O Biobob® é um dispositivo para imobilização celular utilizado como suporte inerte para adesão da biomassa nos reatores biológicos, o qual consiste em uma matriz de poliuretano envolta por uma estrutura rígida de polipropileno, com geometria cilíndrica de $45 \mathrm{~mm}$ de diâmetro e $60 \mathrm{~mm}$ de altura.

Na Figura 4.7 são apresentadas as fotos ilustrativas do suporte utilizado no reator de leito empacotado.

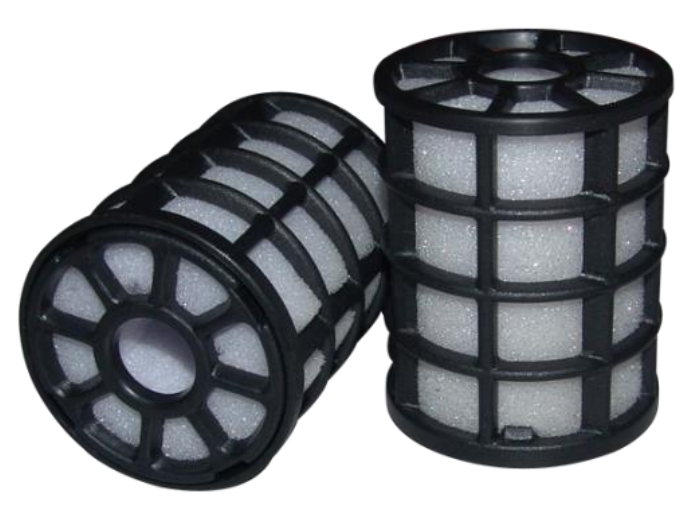

(a)

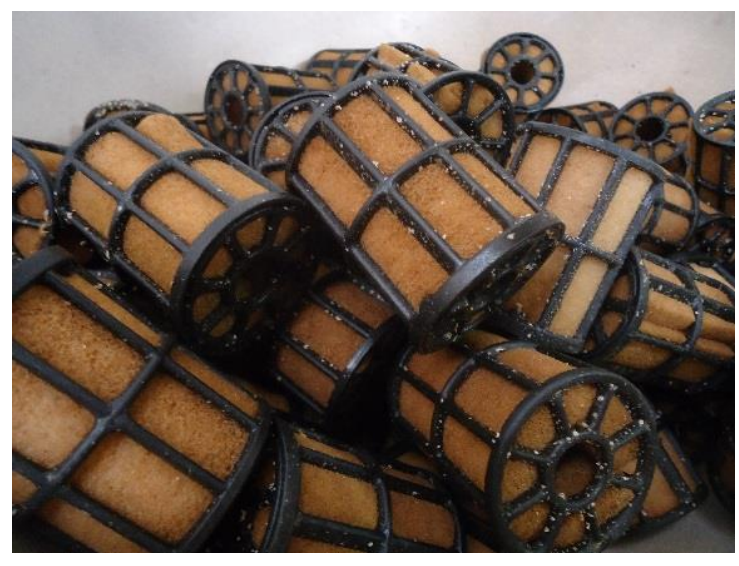

(b)

Figura 4.7 - Fotos do material suporte Biobob®: (a) sem biomassa e (b) com biomassa aderida.

A descrição e as características do material suporte utilizado no reator de leito empacotado são apresentadas na Tabela 4.1.

Tabela 4.1 - Características do suporte utilizado para imobilização da biomassa.

\begin{tabular}{lc}
\cline { 2 - 2 } & Material suporte Biobob® \\
\hline Descrição do material suporte & $\begin{array}{c}\text { Espumas de PU envolta em } \\
\text { anel de polipropileno }\end{array}$ \\
Diâmetro $(\mathrm{mm})$ & 45 \\
Altura cilíndrica $(\mathrm{mm})$ & 60 \\
Massa seca unitária $(\mathrm{g})$ & 12 \\
Massa úmida unitária $(\mathrm{g})$ & 61 \\
Porosidade $(\%)$ & 90 \\
\hline
\end{tabular}




\section{4 ÁGUA RESIDUÁRIA}

A água residuária estudada, afluente ao reator anaeróbio, era proveniente do tratamento preliminar, após gradeamento e caixa de areia, da estação de tratamento de esgoto sanitário Itaipu (ETE Itaipu). As características médias deste esgoto sanitário são apresentadas na Tabela 4.2.

Tabela 4.2 - Composição média do esgoto sanitário estudado.

\begin{tabular}{cc}
\hline Características & Valor médio \\
\hline $\mathrm{pH}$ & 7,4 \\
DQO total & $506 \mathrm{mg} \mathrm{DQO} . \mathrm{L}^{-1}$ \\
DQO filtrada $(\# 1,2 \mu \mathrm{m})$ & $189 \mathrm{mg} \mathrm{DQO} \cdot \mathrm{L}^{-1}$ \\
$\mathrm{DBO}_{5,20^{\circ}}$ & $200 \mathrm{mg} \mathrm{DBO} . \mathrm{L}^{-1}$ \\
$\mathrm{NTK}$ & $54 \mathrm{mg} \mathrm{N} . \mathrm{L}^{-1}$ \\
$\mathrm{~N}^{-\mathrm{NH}_{4}}{ }^{+}$ & $38 \mathrm{mg} \mathrm{N}-\mathrm{NH}_{4}{ }^{+} . \mathrm{L}^{-1}$ \\
Sólidos totais & $608 \mathrm{mg} \mathrm{ST} . \mathrm{L}^{-1}$ \\
Sólidos suspensos totais & $215 \mathrm{mg} \mathrm{SST} . \mathrm{L}^{-1}$ \\
Sólidos suspensos voláteis & $154 \mathrm{mg} \mathrm{SSV} . \mathrm{L}^{-1}$ \\
Alcalinidade a bicarbonato & $214 \mathrm{mg} \mathrm{CaCO} \cdot \mathrm{L}^{-1}$ \\
Ácidos voláteis & $71 \mathrm{mg} \mathrm{CH}{\mathrm{COOH} . \mathrm{L}^{-1}}$
\end{tabular}

\subsection{INÓCULO}

Visando a partida rápida do sistema para a etapa inicial, sem o material suporte, o reator anaeróbio operando como um reator UASB foi inoculado com biomassa proveniente do reator UASB tratando esgoto sanitário da ETE Itaipu. O lodo anaeróbio possuía característica floculenta com concentração de sólidos em suspensão totais (SST) de aproximadamente $10 \mathrm{~g} \mathrm{SST.L^{-1 }}$.

Do mesmo modo, visando a partida rápida do sistema para a etapa com o Biobob ${ }^{\circledR}$, o material suporte foi inoculado com a biomassa proveniente do próprio reator piloto operado na etapa inicial como um reator UASB. O lodo anaeróbio possuía característica floculenta com concentração de sólidos em suspensão totais (SST) de

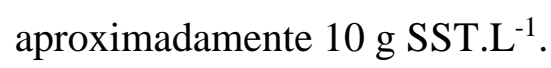




\subsection{ANÁLISES FÍSICO-QUÍMICAS}

Amostras compostas do afluente e efluente do reator foram coletas diariamente por meio de bombas peristálticas automáticas (coleta de $100 \mathrm{~mL}$ a cada $1 \mathrm{~h}$ durante 24 h. $\mathrm{d}^{-1}$ ) e conservadas em temperatura até $4^{\circ} \mathrm{C}$.

Análises de parâmetros como demanda química de oxigênio, nitrogênio amoniacal, nitrogênio total Kjeldahl e sólidos foram realizados segundo o Standard Methods for the Examination of Water and Wastewater (1998). Alcalinidade total e ácidos voláteis totais foram analisadas utilizando método titulométrico proposto por Dilallo \& Albertson (1961) e modificado por Ripley et al. (1986).

Demanda química de oxigênio (DQO): as análises foram realizadas por meio da digestão com refluxo fechado durante duas horas e utilizando-se o método espectrofotométrico com leitura no comprimento de onda de $620 \mathrm{~nm}$. Para DQO filtrada, as amostras foram previamente filtradas a vácuo em membrana de fibra de vidro com poros de $1,2 \mu \mathrm{m}$ de diâmetro.

Demanda bioquímica de oxigênio (DBO): as análises foram realizadas pelo método barimétrico por meio do equipamento OxiTop®.

Nitrogênio amoniacal $\left(\mathbf{N}-\mathbf{N H}_{4}^{+}\right)$: as amostras foram inicialmente destiladas e em seguida analisadas pelo método titulométrico.

Nitrogênio total Kjeldahl (NTK): foi empregado o método macro-Kjeldahl (digestão em meio ácido) seguido por etapa de destilação e análise titulométrica.

Sólidos totais (ST): foram determinados pelo método gravimétrico utilizando-se recipientes de porcelana para secagem das amostras.

Sólidos em suspensão totais (SST) e sólidos em suspensão voláteis (SSV): Foram determinados pelo método gravimétrico, utilizando-se membranas de fibra de vidro com diâmetro de poros igual a $1,2 \mu \mathrm{m}$.

Alcalinidade: as análises de alcalinidade total e à bicarbonato foram realizadas por método titulométrico e expressas em concentração de carbonato de cálcio.

Ácidos voláteis totais: as análises de ácidos voláteis totais foram realizadas por método titulométrico e expressas em concentração de ácido acético.

Volume de Biogás: foi quantificado por meio de um medidor de vazão do tipo turbina.

Potencial hidrogeniônico (pH): as medidas de $\mathrm{pH}$ foram realizadas por método potenciométrico (pHmetro). 


\subsubsection{Quantificação da biomassa aderida nos suportes}

Para quantificar a biomassa aderida ao suporte o procedimento analítico desenvolvido por Araujo Junior e Zaiat (2006) foi aplicado:

1) Coletou-se uma porção de suporte no qual a biomassa estava aderida e transferiu-a para um frasco de $50 \mathrm{ml}$;

2) Adicionou-se ao frasco $10 \mathrm{ml}$ de água destilada e adicionou-se também pérolas de vidro;

3) Tampou-se o frasco e agitou-se energicamente durante 20 minutos, promovendo o desprendimento da biomassa do suporte;

4) Após agitação, o líquido foi separado do suporte e das pérolas de vidro e transferido para uma cápsula de porcelana de $50 \mathrm{ml}$, previamente pesada $\left(\mathrm{P}_{0}\right)$. A porção de suporte foi transferida para uma cápsula de vidro. Utilizou-se cerca de $5 \mathrm{ml}$ de água destilada para lavagem das pérolas de vidro;

5) A cápsula de porcelana contendo o líquido separado e a cápsula de vidro contendo o suporte foram levadas à estufa, ajustada para temperatura de $105^{\circ} \mathrm{C}$, onde permaneceram até peso constante por cerca de 24 horas;

6) Decorrido o tempo de secagem, a cápsula de porcelana e os suportes foram pesados, obtendo-se as respectivas massas $\mathrm{P}_{1}$ e $\mathrm{P}_{\text {suporte; }}$;

7) Após pesagem, a cápsula de porcelana foi transferida para a mufla, ajustada para temperatura de $500^{\circ} \mathrm{C}$, onde permaneceu por 2 horas;

8) Finalmente, após a calcinação na mufla, a cápsula de porcelana contendo o líquido separado novamente foi pesada, obtendo-se o valor de $\mathrm{P}_{2}$;

Este procedimento foi executado ao final da etapa experimental, quando as amostras de suporte de espuma de poliuretano foram retiradas após a abertura do reator.

Assim, calculou-se a massa de sólidos totais (ST) e sólidos voláteis totais (SVT) aderidos por massa de suporte, conforme apresentados nas Equações 4.1 e 4.2.

$$
\begin{gathered}
S T=\frac{P_{1}-P_{0}}{P_{\text {suporte }}} \\
S V T=\frac{P_{1}-P_{2}}{P_{\text {suporte }}}
\end{gathered}
$$




\subsection{CÁlCULO dO RENDIMENTO E PRODUÇÃo DE SÓLIDOS (Y Yobs; Pl)}

Devido ao longo período de operação do HAnR, compreendido entre o $69^{\circ}$ e o $468^{\circ}$ dia, considerou-se o estado de equilíbrio dinâmico aparente para o sistema, ou seja, o que se produzia de sólidos também era o que se descartava de sólidos. Deste modo, o rendimento e a produção de sólidos foi estimado por meio da quantidade total de sólidos descartado, tanto pela via convencional (descarte do leito de lodo) quanto pela perda involuntária de sólidos no efluente tratado, de acordo com as Equações 4.3 e 4.4.

$$
\begin{gathered}
\mathrm{Y}_{\text {obs }}=\frac{\sum_{\mathrm{i}=69}^{468} \mathrm{~V}_{\mathrm{d}, \mathrm{i}} \cdot \mathrm{X}_{\mathrm{d}, \mathrm{i}}+\sum_{\mathrm{i}=69}^{468} \mathrm{Q}_{\mathrm{i}} \cdot \mathrm{X}_{\mathrm{e}, \mathrm{i}}}{\sum_{\mathrm{i}=69}^{468}\left(\mathrm{~S}_{0}-\mathrm{S}\right)_{\mathrm{i}} \cdot \mathrm{Q}_{\mathrm{i}}} \\
\mathrm{P}_{\text {Lodo }}=\frac{\sum_{\mathrm{i}=69}^{468} \mathrm{~V}_{\mathrm{d}, \mathrm{i}} \cdot \mathrm{X}_{\mathrm{d}, \mathrm{i}}^{\prime}+\sum_{\mathrm{i}=69}^{468} \mathrm{Q}_{\mathrm{i}} \cdot \mathrm{X}_{\mathrm{e}, \mathrm{i}}^{\prime}}{\sum_{\mathrm{i}=69}^{468}\left(\mathrm{~S}_{0}\right)_{\mathrm{i}} \cdot \mathrm{Q}_{\mathrm{i}}}
\end{gathered}
$$

Onde o $\mathrm{Y}_{\mathrm{obs}}$ é o rendimento da produção de sólidos observada (g SSV.g-1 DQO $\left._{\text {removida }}\right), \mathrm{V}_{\mathrm{d}}$ é o volume de lodo descartado do reator $\left(\mathrm{m}^{3}\right), \mathrm{X}_{\mathrm{d}}$ representa a

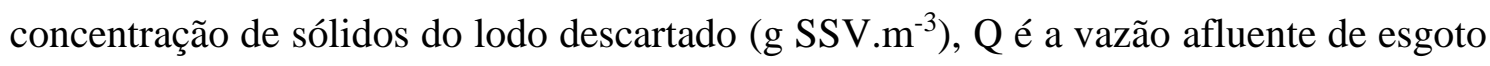
$\left(\mathrm{m}^{3} \cdot \mathrm{d}^{-1}\right), \mathrm{X}_{\mathrm{e}}$ é a concentração de sólidos no efluente (g SSV.m $\left.{ }^{-3}\right), \mathrm{S}_{0}$ é a concentração do substrato no afluente (g DQO. $\mathrm{m}^{-3}$ ), S é a concentração de substrato no efluente (g DQO. $\mathrm{m}^{-}$

$\left.{ }^{3}\right)$ e i é o dia operacional. PLodo é a produção de sólidos (g ST.g ${ }^{-1} \mathrm{DQO}_{\text {aplicada }}$ ), $\mathrm{X}_{\mathrm{d}}$ representa a concentração de sólidos do lodo descartado (g SST.m ${ }^{-3}$ ) e X'e é a concentração de sólidos no efluente (g SST.m $\left.{ }^{-3}\right)$.

\subsection{CÁLCULO DO RENDIMENTO DA PRODUÇão METANO}

O rendimento da produção de metano foi obtido na condições normais de temperatura e pressão, de acordo com a Equação 4.4, por meio da Lei dos Gases Ideais.

$$
\mathrm{P}_{\mathrm{CH} 4, \mathrm{i}}=\frac{\mathrm{MM}_{C H 4, i} \cdot \frac{P_{C H 4, i} \cdot V_{C H 4, i}}{R \cdot T_{i}}}{\left(\mathrm{~S}_{0}-\mathrm{S}\right)_{\mathrm{i}} \cdot \mathrm{Q}_{\mathrm{i}}}
$$

Onde o $\mathrm{P}_{\mathrm{CH} 4}$ é o rendimento da produção de metano ( $\left.\mathrm{g} \mathrm{CH}_{4} \cdot \mathrm{g}^{-1} \mathrm{DQO}_{\text {total removida }}\right)$, $\mathrm{MM}_{\mathrm{CH} 4}$ é a massa molecular do metano $\left(\mathrm{g} \cdot \mathrm{mol}^{-1}\right), \mathrm{P}_{-} \mathrm{CH} 4$,atm é a pressão do metano quando liberado para a atmosfera (1,0 atm), $\mathrm{V}_{\mathrm{CH} 4}$ é o volume de metano produzido (L), R é a constante universal dos gases ideais $\left(0,08206\right.$ atm.L.mol $\left.{ }^{-1} \cdot \mathrm{K}^{-1}\right)$, T é a temperatura do metano $(\mathrm{K}), \mathrm{Q}$ é a vazão afluente de esgoto $\left(\mathrm{m}^{3} \cdot \mathrm{d}^{-1}\right), \mathrm{X}_{\mathrm{e}}$ é a concentração de sólidos no efluente $\left(\mathrm{g} \mathrm{SSV} \cdot \mathrm{m}^{-3}\right), \mathrm{S}_{0}$ é a concentração do substrato no afluente $\left(\mathrm{g} \mathrm{DQO}_{\mathrm{t}} \cdot \mathrm{m}^{-3}\right), \mathrm{S}$ é a concentração de substrato no efluente $\left(\mathrm{g}\right.$ DQO. $\left.\mathrm{m}^{-3}\right)$ e i é o dia operacional. 


\subsection{PROCEDIMENTO EXPERIMENTAL}

A investigação experimental foi realizada em seis etapas principais e mais três etapas adicionais. Na primeira estudou-se o comportamento do reator anaeróbio operando como um reator UASB contendo biomassa auto-imobilizada, sem a adição do material suporte Biobob®. Posteriormente, na segunda etapa, adicionou-se o material suporte Biobob® no leito reacional do reator, avaliando-se o comportamento do mesmo operando em condições similares a primeira etapa. Nas etapas subsequentes, terceira a sexta, a vazão afluente ao reator anaeróbio, contendo biomassa imobilizada, foi aumentada gradativamente avaliando-se o comportamento e o desempenho do mesmo. Por fim, nas etapas sétima a nona, repetiram-se as mesmas condições operacionais das etapas quarta, sexta e segunda, respectivamente, devido às baixas concentrações apresentadas pelo esgoto afluente durante essas etapas prévias. Em todas as etapas, os reatores foram operados continuamente, à temperatura média de $26 \pm 2^{\circ} \mathrm{C}$.

\subsubsection{Etapa 1 - Reator UASB}

Nessa etapa, analisou-se o comportamento do reator anaeróbio operando como um reator UASB, contendo unicamente biomassa auto-imobilizada, verificando a sua eficiência na remoção de matéria orgânica e sólidos em suspensão provenientes do substrato. O reator foi montado com um único módulo, como mostrado na Figura 4.8.

O volume total do reator anaeróbio era de $12,5 \mathrm{~m}^{3}$, sendo $0,4 \mathrm{~m}^{3}$ da câmara de alimentação, $8,0 \mathrm{~m}^{3}$ do leito reacional (leito e manta de lodo), $3,8 \mathrm{~m}^{3}$ da câmara do separador trifásico e $0,3 \mathrm{~m}^{3}$ da câmara de saída. Para o cálculo do volume útil do reator, considerou-se o mesmo obtido para o volume total, $12,5 \mathrm{~m}^{3}$, desprezando-se o volume ocupado pelas tubulações de alimentação e pelos defletores de gás e separador trifásico.

Como procedimento de inoculação do reator, $6,3 \mathrm{~m}^{3}$ de lodo de inóculo foram transferidos diretamente do reator UASB tratando esgoto sanitário da ETE Itaipu para o reator piloto. Finalizada a transferência, completou-se o volume do reator com água de abastecimento, ficando pronto para iniciar a primeira etapa de operação. Como a biomassa inoculada já estava adaptada ao esgoto sanitário afluente ao reator piloto, o reator UASB foi posto em marcha sem rampa de alimentação, fixando-se a vazão afluente em $1,4 \mathrm{~m}^{3} \cdot \mathrm{h}^{-1}$, dando início assim a primeira etapa. 
Como procedimento de quantificação somente do metano $\left(\mathrm{CH}_{4}\right)$ produzido, no selo hídrico de volume útil igual a $0,2 \mathrm{~m}^{3}$, uma solução alcalina de hidróxido de sódio $(\mathrm{NaOH})$ foi mantida com $\mathrm{pH}$ acima de 11 para sequestrar o gás sulfídrico $\left(\mathrm{H}_{2} \mathrm{~S}\right)$ e o dióxido de carbono $\left(\mathrm{CO}_{2}\right)$ presentes no biogás. O selo hídrico foi mantido fechado hermeticamente controlando-se a pressão dentro do separador trifásico em 0,6 mca.

Buscando obter as mesmas condições operacionais do reator UASB tratando esgoto sanitário da ETE Itaipu, para esta primeira etapa fixou-se a vazão de alimentação em $1,4 \mathrm{~m}^{3} \cdot \mathrm{h}^{-1}$ e verificou-se a eficiência do sistema na remoção de matéria orgânica e sólidos em suspensão. Para esta condição, o tempo de detenção hidráulica foi mantido em $8,8 \mathrm{~h}$.

Para a avaliação de desempenho do sistema foram coletadas amostras diárias do afluente e do efluente do reator e analisadas conforme apresentado no item 4.6.

As variáveis analisadas durante a operação do reator UASB, os métodos utilizados e as frequências das análises são apresentadas na Tabela 4.3.

Tabela 4.3 - Variáveis analisadas, métodos utilizados e frequência de amostragem durante a operação do reator UASB.

\begin{tabular}{|c|c|c|c|}
\hline Variáveis analisadas & $\begin{array}{c}\text { Pontos de } \\
\text { amostragem }^{\mathrm{a}}\end{array}$ & Método analítico & $\begin{array}{c}\text { Frequência } \\
\text { semanal }\end{array}$ \\
\hline Temperatura $\left({ }^{\circ} \mathrm{C}\right)$ & A e E & Termométrico & 5 a 6 vezes \\
\hline $\mathrm{pH}$ & $A, E$ e $S$ & Potenciométrico & 5 a 6 vezes \\
\hline Biogás $\left(\mathrm{m}^{3} \mathrm{CH}_{\left.4 \cdot \mathrm{d}^{-1}\right)}\right.$ & $\mathrm{S}$ & Volumétrico & 5 a 6 vezes \\
\hline Alcalinidade $\left(\mathrm{mg} \mathrm{CaCO}_{3} \cdot \mathrm{L}^{-1}\right)$ & $A$ e $E$ & Titulométrico & 5 a 6 vezes \\
\hline Ácidos voláteis (mg HAc. $\mathrm{L}^{-1}$ ) & A e E & Titulométrico & 5 a 6 vezes \\
\hline DQO total $\left(\mathrm{mg} \mathrm{O}_{2} \cdot \mathrm{L}^{-1}\right)$ & A e E & Espectrofotométrico & 5 a 6 vezes \\
\hline DQO filtrada $\left(\mathrm{mg} \mathrm{O}_{2} \cdot \mathrm{L}^{-1}\right)$ & A e E & Espectrofotométrico & 5 a 6 vezes \\
\hline $\mathrm{DBO}_{5,20}\left(\mathrm{mg} \mathrm{O}_{2} \cdot \mathrm{L}^{-1}\right)$ & A e E & Barimétrico & $1 \mathrm{vez}$ \\
\hline N-NTK (mg N.L ${ }^{-1}$ ) & A e E & Titulométrico & 5 a 6 vezes \\
\hline $\mathrm{N}-\mathrm{NH}_{4}{ }^{+}\left(\mathrm{mg}\right.$ N.L $\left.{ }^{-1}\right)$ & A e E & Titulométrico & 5 a 6 vezes \\
\hline $\mathrm{ST}\left(\mathrm{mg} \mathrm{ST.L^{-1 }}\right)$ & A e E & Gravimétrico & 5 a 6 vezes \\
\hline SST (mg SST.L $\left.{ }^{-1}\right)$ & A e E & Gravimétrico & 5 a 6 vezes \\
\hline SSV (mg SSV.L $\left.L^{-1}\right)$ & A e E & Gravimétrico & 5 a 6 vezes \\
\hline
\end{tabular}




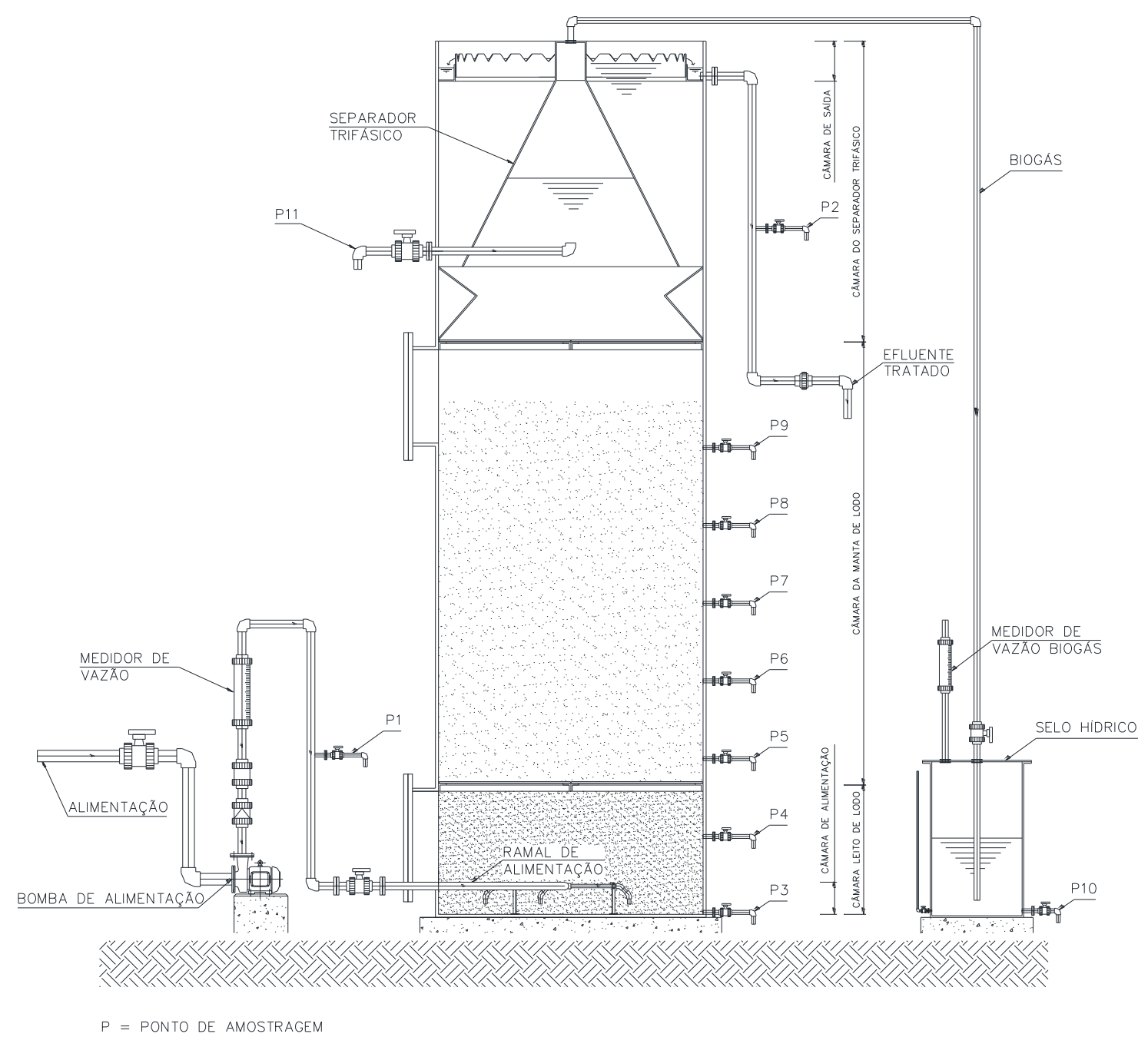

Figura 4.8 - Desenho esquemático do reator UASB.

\subsubsection{Etapas 2 a 9 - Reator anaeróbio híbrido (leito fixo e manta de lodo)}

Nessas etapas, analisou-se o comportamento do reator anaeróbio operando como um reator híbrido (HAnR), contendo $5 \mathrm{~m}^{3}$ do material suporte Biobob® no leito reacional (biomassa imobilizada), verificando a sua eficiência na remoção de matéria orgânica e sólidos em suspensão provenientes do substrato. $\mathrm{O}$ reator foi o mesmo utilizado na primeira etapa, apenas tendo sido adicionado o material suporte no leito reacional, como mostrado na Figura 4.9.

O volume total do reator anaeróbio era de $12,5 \mathrm{~m}^{3}$, sendo $0,4 \mathrm{~m}^{3}$ da câmara de alimentação, 1,9 $\mathrm{m}^{3}$ do leito de lodo, 6,4 $\mathrm{m}^{3}$ do leito reacional (leito de Biobobß), 3,8 $\mathrm{m}^{3}$ da câmara do separador trifásico e $0,3 \mathrm{~m}^{3}$ da câmara de saída. Como a porosidade do leito de Biobob® era de $70 \%$, o reator anaeróbio possuía volume líquido total de $11,0 \mathrm{~m}^{3}$. Para o cálculo do volume útil do reator, considerou-se o mesmo obtido para o volume total de 
líquido, 11,0 $\mathrm{m}^{3}$, desprezando-se o volume ocupado pelas tubulações de alimentação e pelos defletores de gás e separador trifásico.

Como procedimento de inoculação do reator, o lodo de inóculo foi o mesmo lodo formado no próprio reator piloto operado na etapa inicial como um reator UASB. Finalizada a adição do material suporte Biobob® no leito reacional, 6,3 $\mathrm{m}^{3}$ de lodo de inóculo foram adicionados sobre o leito reacional, por meio da boca de inspeção superior do reator, entrando em contato com o material suporte Biobob®. Completou-se o volume do reator com água de abastecimento e aguardou-se por um período de $24 \mathrm{~h}$ antes de iniciar a segunda etapa. Como a biomassa inoculada já estava adaptada ao esgoto sanitário afluente ao reator piloto, o reator anaeróbio foi posto em marcha sem rampa de alimentação, fixando-se a vazão afluente em $1,4 \mathrm{~m}^{3} \cdot \mathrm{h}^{-1}$, dando início assim a segunda etapa.

Como procedimento de quantificação somente do metano $\left(\mathrm{CH}_{4}\right)$ produzido, foi mantido o mesmo sistema de medida da primeira etapa.

Buscando avaliar o desempenho do reator mediante a aplicação de altas cargas volumétricas e altas velocidades ascensionais, para as etapas subsequentes, terceira a sexta, a vazão de alimentação foi aumentada gradativamente (incremento de $0,36 \mathrm{~m}^{3} \cdot \mathrm{h}^{-1}$ por etapa) até que se alcançou a vazão afluente de $2,8 \mathrm{~m}^{3} \cdot \mathrm{h}^{-1}$ (valor correspondente a $200 \%$ da vazão de projeto da ETE Itaipu) e verificou-se a eficiência do sistema na remoção de matéria orgânica e sólidos suspensos. Para estas condições, o tempo de detenção hidráulica foi reduzido de $7,5 \mathrm{~h}$ para 3,9 h. Para as etapas sétima a nona, as vazões afluentes de $2,1 \mathrm{~m}^{3} \cdot \mathrm{h}^{-1}\left(5,2 \mathrm{~h}\right.$ de TDH), $2,8 \mathrm{~m}^{3} \cdot \mathrm{h}^{-1}$ (3,9 h de TDH) e 1,4 $\mathrm{m}^{3} \cdot \mathrm{h}^{-1}$ (7,5 $\mathrm{h}$ de $\mathrm{TDH})$ foram repetidas, respectivamente.

Para a avaliação de desempenho do sistema foram coletadas amostras diárias do afluente e do efluente do reator e analisadas conforme apresentado no item 4.6.

As variáveis analisadas durante a operação do reator HAnR, os métodos utilizados e as frequências das análises foram os mesmos da primeira etapa. 


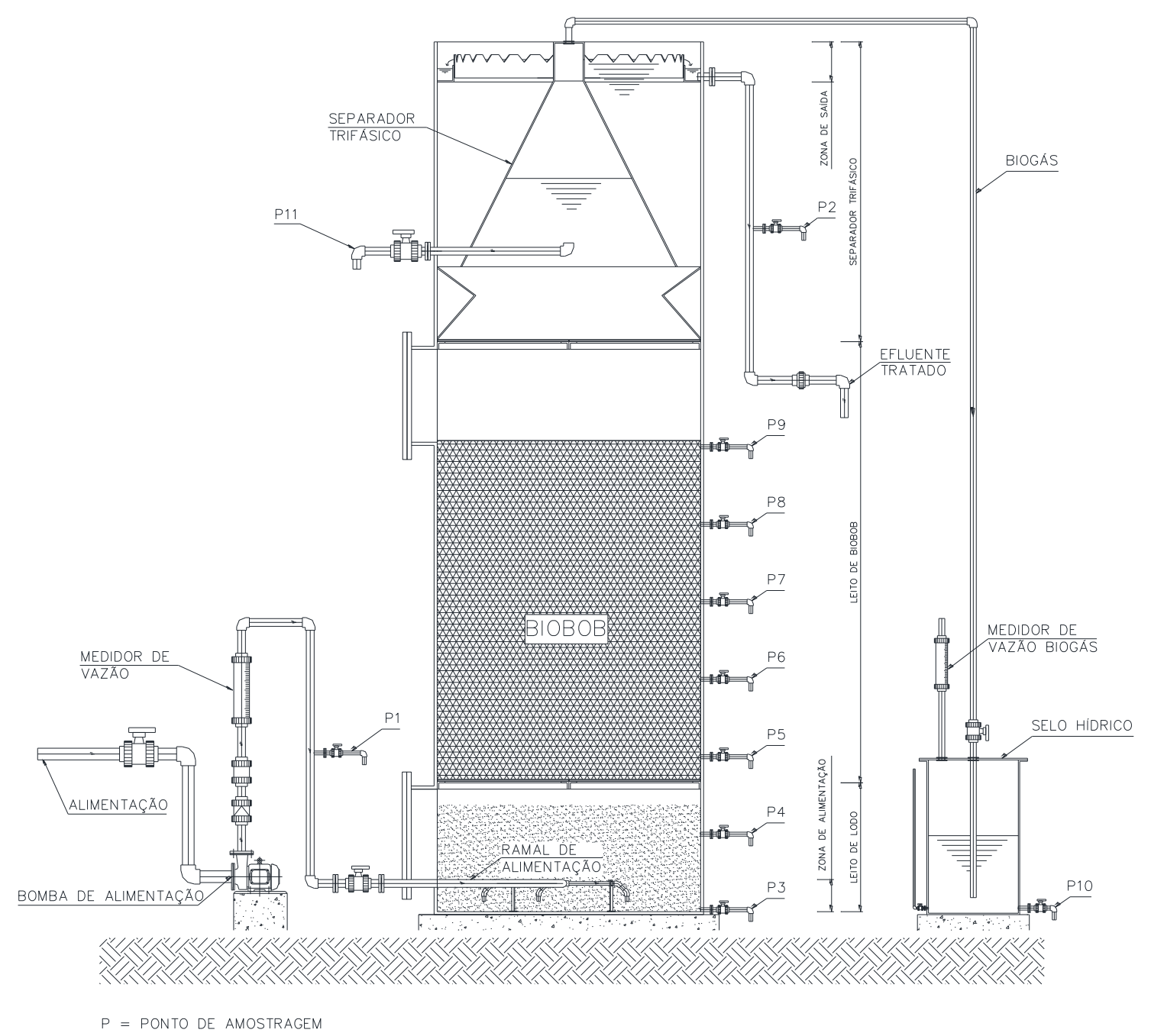

Figura 4.9 - Desenho esquemático do reator HAnR.

\subsubsection{Resumo das etapas experimentais}

$\mathrm{Na}$ Tabela 4.4 é apresentado o resumo das etapas experimentais do reator anaeróbio, contendo o tempo de operação, a vazão de alimentação (Q), a velocidade ascensional $\left(\mathrm{v}_{\mathrm{s}}\right)$, o tempo de detenção hidráulica $(\mathrm{TDH})$ e o volume de material suporte aplicados para cada etapa. 
Tabela 4.4 - Resumo das etapas experimentais do reator anaeróbio.

\begin{tabular}{cccccc}
\hline $\begin{array}{c}\text { Etapa } \\
\text { experimental }\end{array}$ & $\begin{array}{c}\text { Tempo de } \\
\text { operação }(\mathbf{d})\end{array}$ & $\begin{array}{c}\mathbf{Q} \\
\left(\mathbf{m}^{\mathbf{3}} \cdot \mathbf{h}^{-\mathbf{1}}\right)\end{array}$ & $\begin{array}{c}\mathbf{v s} \\
\left(\mathbf{m}_{\mathbf{m}} \mathbf{- 1}\right)\end{array}$ & $\begin{array}{c}\text { TDH } \\
(\mathbf{h})\end{array}$ & $\begin{array}{c}\text { Volume de Biobob® } \\
\left(\mathbf{m}^{\mathbf{3}}\right)\end{array}$ \\
\hline $\mathbf{1}$ & 68 & 1,4 & 0,63 & 8,8 & 0 \\
$\mathbf{2}$ & 25 & 1,5 & 0,66 & 7,4 & 5 \\
$\mathbf{3}$ & 31 & 1,8 & 0,79 & 6,1 & 5 \\
$\mathbf{4}$ & 49 & 2,1 & 0,94 & 5,2 & 5 \\
$\mathbf{5}$ & 30 & 2,5 & 1,11 & 4,4 & 5 \\
$\mathbf{6}$ & 79 & 2,8 & 1,25 & 3,9 & 5 \\
$\mathbf{7}^{\mathbf{a}}$ & 73 & 2,1 & 0,94 & 5,2 & 5 \\
$\mathbf{8}^{\mathbf{b}}$ & 60 & 2,8 & 1,25 & 3,9 & 5 \\
$\mathbf{9}^{\mathbf{c}}$ & 53 & 1,5 & 0,65 & 7,5 & 5 \\
\hline
\end{tabular}

${ }^{\mathrm{a}}$ Etapa 7 submetida às mesmas condições operacionais da Etapa 4;

${ }^{\mathrm{b}}$ Etapa 8 submetida às mesmas condições operacionais da Etapa 6;

${ }^{c}$ Etapa 9 submetida às mesmas condições operacionais da Etapa 2. 



\section{Resultados e Discussão}

Como mencionado em Material e Métodos, a investigação experimental foi realizada em seis etapas principais e mais três etapas adicionais, correspondendo no total a 468 dias ininterruptos de operação do reator anaeróbio. A primeira etapa compreendeu o início da operação do reator anaeróbio em 21 de Julho de 2012, operando como um reator UASB contendo biomassa auto-imobilizada, até a adição do material suporte Biobob® no $69^{\circ}$ dia de operação. A segunda etapa compreendeu o início da operação do reator anaeróbio híbrido (HAnR), contendo em seu leito reacional o material suporte Biobob®, tendo sido operado em condições similares às da primeira etapa até o $93^{\circ}$ dia. As etapas subsequentes, terceira a nona, compreenderam a aplicação de diferentes tempos de detenção hidráulica (TDH), por meio da variação da vazão afluente ao HAnR, entre o $94^{\circ}$ e o $468^{\circ}$ dia de operação. Neste capítulo são apresentados os resultados e discussões referentes às nove etapas de operação, bem como os exames para quantificação da biomassa imobilizada no material suporte realizados ao final do trabalho experimental.

\subsection{OPERAÇÃO DO REATOR ANAERÓBIO}

O reator UASB foi posto em marcha sem rampa de alimentação, fixando-se a vazão afluente em $1,4 \mathrm{~m}^{3} \cdot \mathrm{h}^{-1}$, velocidade ascensional aparente (relação entre a vazão afluente e a seção transversal do reator) em $0,63 \mathrm{~m} \cdot \mathrm{h}^{-1}$ e com TDH de 8,8 horas, com base no volume útil do reator $\left(12,5 \mathrm{~m}^{3}\right)$, dando início assim à primeira etapa.

Devido à inoculação do reator UASB com lodo proveniente do reator UASB da ETE Itaipu, o reator piloto teve partida rápida, atingindo eficiências acima de $60 \%$ na remoção de $\mathrm{DQO}_{\mathrm{t}}$ (demanda química de oxigênio total) e SST (sólidos suspensos totais) a partir do $1^{\circ}$ dia de operação. O reator foi operado continuamente nesta condição por um 
período de 68 dias, com temperatura ambiente média de $24 \pm 1^{\circ} \mathrm{C}$, produzindo-se um efluente tratado com valores médios de $236 \pm 83 \mathrm{mg} \mathrm{DQO}_{\mathrm{t} \mathrm{L}} \mathrm{m}^{-1}$ e $95 \pm 63 \mathrm{mg} \mathrm{SST} \mathrm{L}^{-1}$ e obtendo-se eficiências médias na remoção de $\mathrm{DQO}_{\mathrm{t}}\left(\mathrm{E}_{\mathrm{DQO}}\right)$ e SST (ESST) iguais a $61 \pm 12 \%$ e $60 \pm 23 \%$, respectivamente.

No $69^{\circ}$ dia, a operação do reator UASB foi paralisada por um período de 5 h e 5 $\mathrm{m}^{3}$ do material suporte Biobob ${ }^{\circledR}$ foram adicionados, manualmente, em seu leito reacional. De modo semelhante a primeira etapa, o HAnR foi posto em marcha sem rampa de alimentação, mantendo-se a vazão afluente em $1,4 \mathrm{~m}^{3} \cdot \mathrm{h}^{-1}$, velocidade ascensional aparente $\left(\mathrm{v}_{\mathrm{s}}\right)$ em $0,66 \mathrm{~m} \cdot \mathrm{h}^{-1}$, mas com TDH de 7,4 horas, com base no volume útil do reator $\left(11,0 \mathrm{~m}^{3}\right)$, dando início assim a segunda etapa.

Semelhantemente ao reator UASB, o HAnR também teve partida rápida, atingindo eficiências acima de $70 \%$ na remoção de $\mathrm{DQO}_{\mathrm{t}}$ e SST a partir do $1^{\circ}$ dia de operação, devido à inoculação ter ocorrido com lodo proveniente do próprio reator piloto operado na etapa inicial como um reator UASB. O reator foi operado continuamente nesta condição por um período de 25 dias, com temperatura ambiente média de $25 \pm 1^{\circ} \mathrm{C}$, obtendo-se eficiências médias na remoção de DQO $_{t}$ e SST iguais a $72 \pm 10 \%$ e $79 \pm 11 \%$, respectivamente.

A partir do $94^{\circ}$ dia foram aplicados diferentes TDH e cargas orgânicas volumétricas (COV) ao longo da operação do HAnR, acompanhando-se a variação real da DQO e SST do esgoto sanitário estudado. Devido às características do esgoto sanitário, a $\mathrm{DQO}_{\mathrm{t}}, \mathrm{DQO}_{\mathrm{f}}$ e o SST afluentes variaram significativamente ao longo da operação do reator, tendo valores médios de $488 \pm 155 \mathrm{mg} . \mathrm{L}^{-1}$, $177 \pm 58 \mathrm{mg} . \mathrm{L}^{-1}$ e $214 \pm 75 \mathrm{mg} . \mathrm{L}^{-1}$, respectivamente. Apesar destas oscilações, o HAnR mostrou-se robusto aos choques de carga durante toda a operação independentemente do TDH aplicado, produzindo um efluente tratado de melhor qualidade do que o obtido com o reator UASB, com valores médios de $197 \pm 56 \mathrm{mg}$ DQO $_{\mathrm{t}} \mathrm{L}^{-1}, 105 \pm 35 \mathrm{mg} \mathrm{DQO}_{\mathrm{f}} \mathrm{L}^{-1}$ e $69 \pm 35 \mathrm{mg} \mathrm{SST} \mathrm{L}^{-1}$.

Os perfis de DQO e SST afluente e efluente ao reator em cada etapa de operação, bem como os gráficos Box-plot de distribuição dos resultados para cada TDH aplicado são apresentados na Figura 5.1, Figura 5.4, Figura 5.2, Figura 5.3 e Figura 5.5, respectivamente.

A representação Box-plot é uma ferramenta estatística que possibilita a visualização da distribuição dos pontos amostrados, apresentando no box a mediana (50\%), o primeiro quartil (25\%) e o terceiro quartil (75\%). São discriminados também os valores máximos e mínimos da distribuição. Para esse tipo de representação pode-se 
afirmar que quanto maior o comprimento do box interior maior será a heterogeneidade da amostra, consequentemente, maior será o desvio padrão.

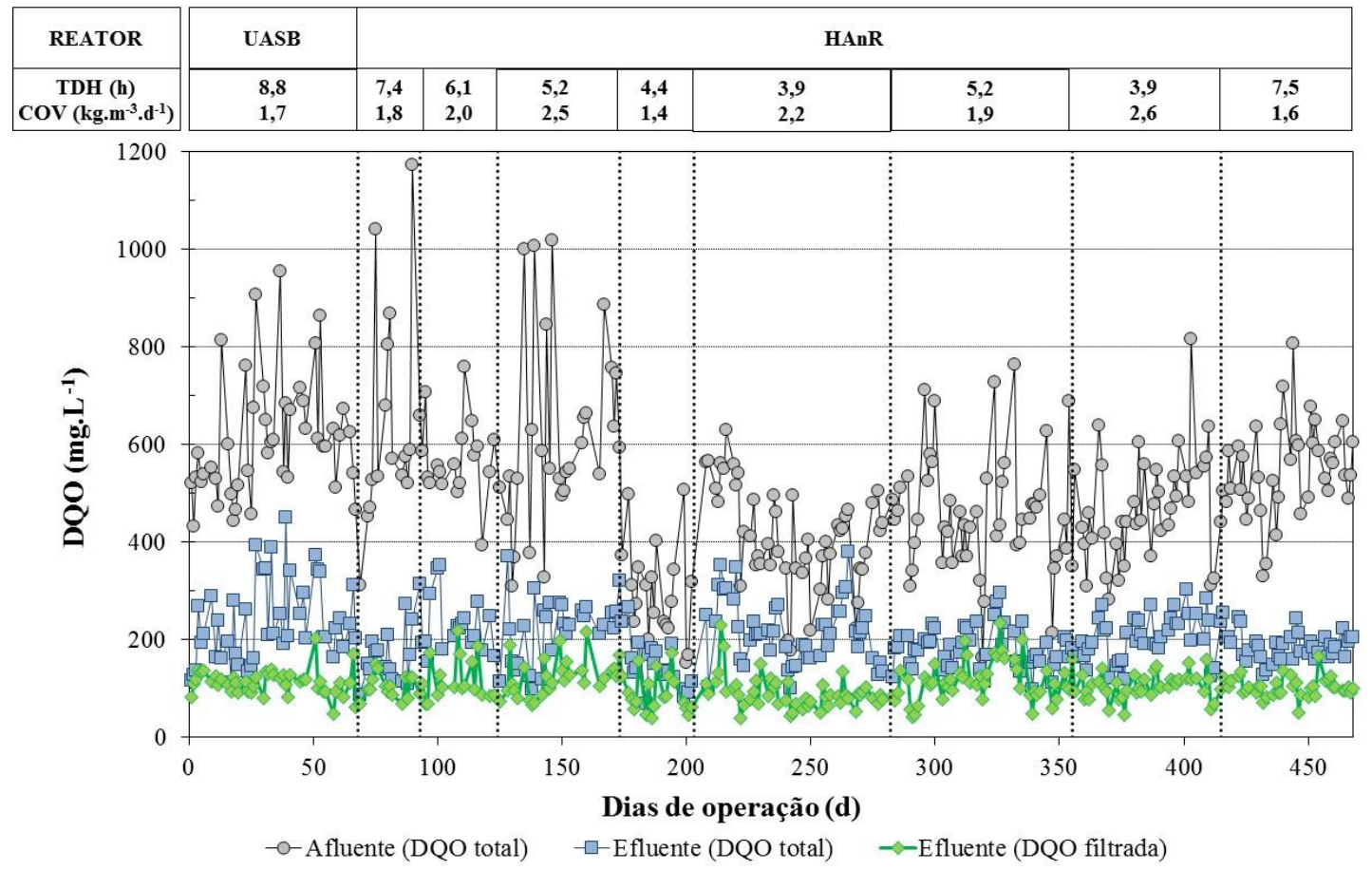

Figura 5.1 - Valores de DQO afluente e efluente ao longo da operação do reator anaeróbio.

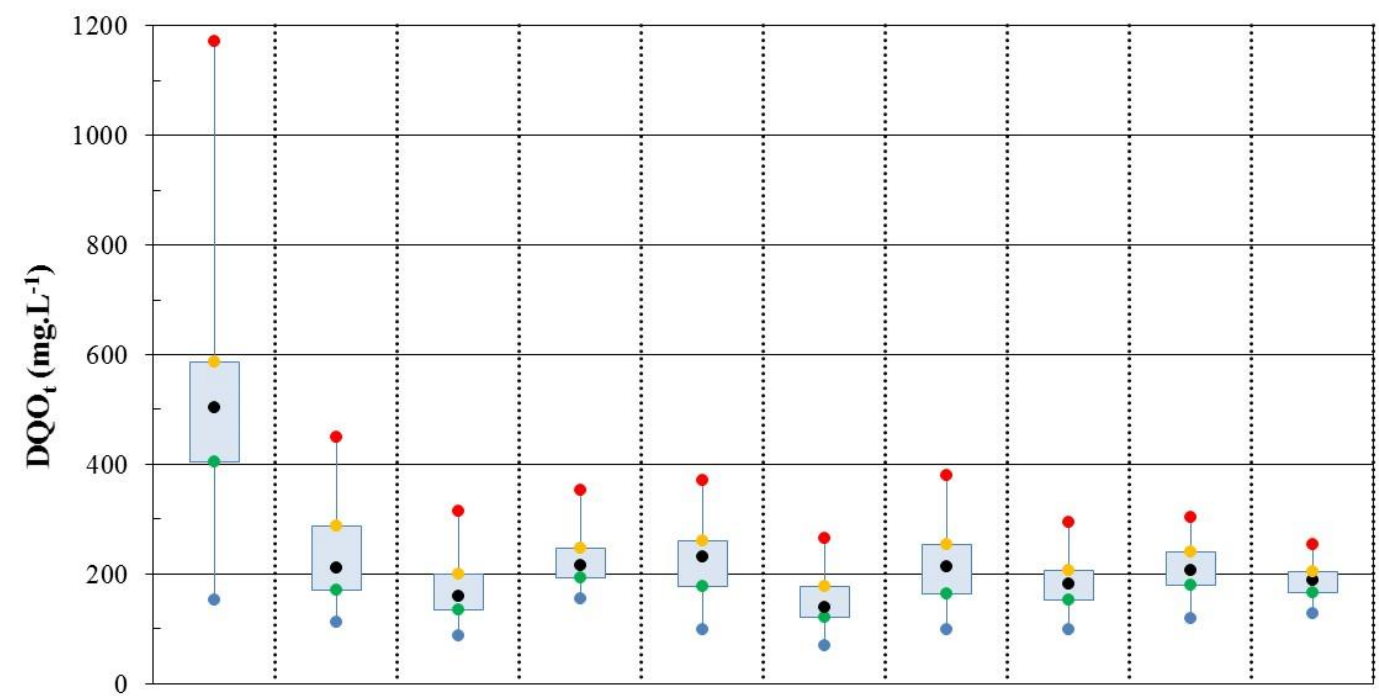

\begin{tabular}{|c|c|c|c|c|c|c|c|c|c|c|}
\hline $\begin{array}{c}\text { TDH (h) } \\
\operatorname{COV}\left(\mathrm{kg} \cdot \mathrm{m}^{-3} \cdot \mathrm{d}^{-1}\right)\end{array}$ & Aflunte & $\begin{array}{l}\mathbf{8 , 8} \\
\mathbf{1 , 7} \\
\end{array}$ & $\begin{array}{l}7,4 \\
1,8 \\
\end{array}$ & $\begin{array}{l}6,1 \\
2,0 \\
\end{array}$ & $\begin{array}{l}5,2 \\
2,5\end{array}$ & $\begin{array}{l}\mathbf{4 , 4} \\
\mathbf{1 , 4} \\
\end{array}$ & $\begin{array}{l}3,9 \\
2,2 \\
\end{array}$ & $\begin{array}{l}5,2 \\
1,9 \\
\end{array}$ & $\begin{array}{l}3,9 \\
2,6 \\
\end{array}$ & $\begin{array}{l}7,5 \\
1,6 \\
\end{array}$ \\
\hline REATOR & & UASB & \multicolumn{8}{|c|}{ HAnR } \\
\hline
\end{tabular}

Figura 5.2 - Gráfico Box-plot de distribuição dos resultados de $\mathrm{DQO}_{\mathrm{t}}$ afluente e efluente para cada TDH aplicado ao longo da operação do reator anaeróbio. 


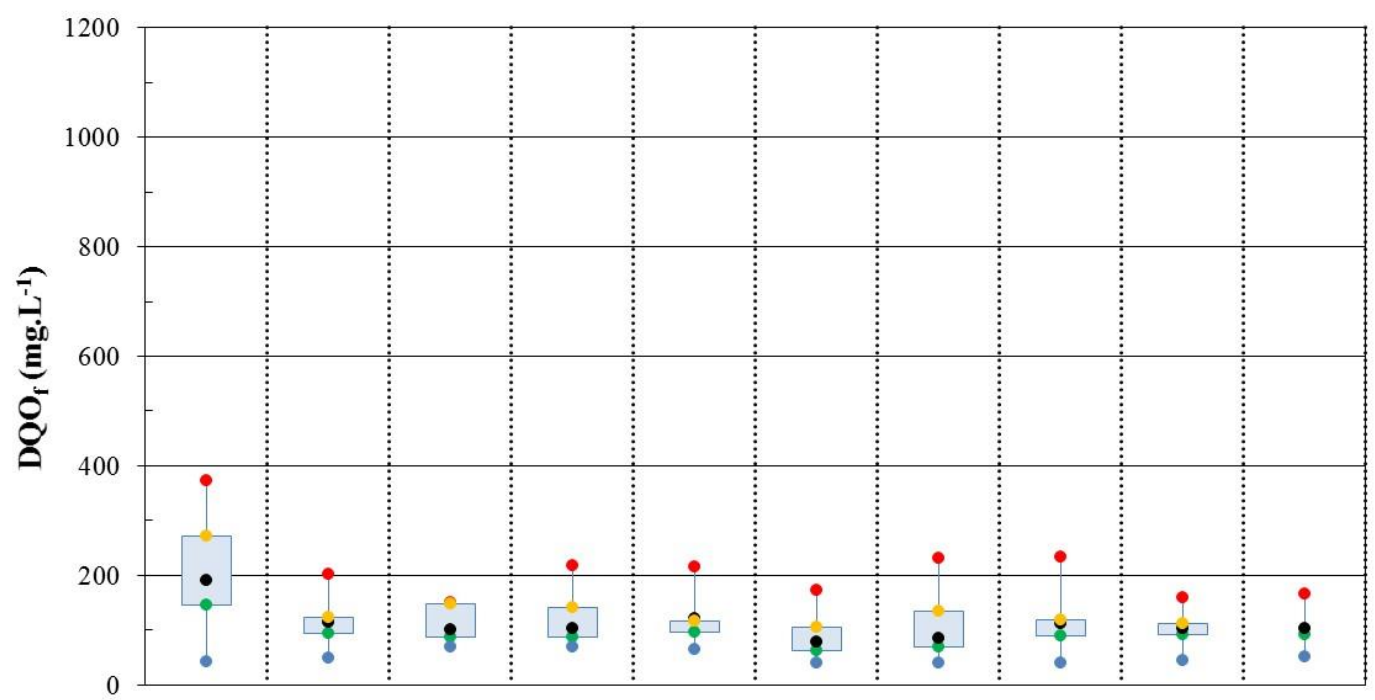

\begin{tabular}{|c|c|c|c|c|c|c|c|c|c|c|}
\hline $\begin{array}{c}\text { TDH }(\mathbf{h}) \\
\operatorname{COV}\left(\mathbf{k g} \cdot \mathrm{m}^{-3} \cdot \mathrm{d}^{-1}\right)\end{array}$ & \multirow{2}{*}{ Afluente } & $\begin{array}{l}8,8 \\
1,7\end{array}$ & $\begin{array}{l}7,4 \\
1,8\end{array}$ & $\begin{array}{l}6,1 \\
2,0\end{array}$ & $\begin{array}{l}5,2 \\
2,5\end{array}$ & $\begin{array}{l}4,4 \\
1,4\end{array}$ & $\begin{array}{l}3,9 \\
2,2\end{array}$ & $\begin{array}{l}5,2 \\
1,9\end{array}$ & $\begin{array}{l}3,9 \\
2,6\end{array}$ & $\begin{array}{l}7,5 \\
1,6\end{array}$ \\
\hline REATOR & & UASB & \multicolumn{8}{|c|}{ HAnR } \\
\hline
\end{tabular}

$\bullet 25 \% \cdot 50 \% \cdot \operatorname{Min} \bullet \operatorname{Max} \cdot 75 \%$

Figura 5.3 - Gráfico Box-plot de distribuição dos resultados de $\mathrm{DQO}_{\mathrm{f}}$ afluente e efluente para cada TDH aplicado ao longo da operação do reator anaeróbio.

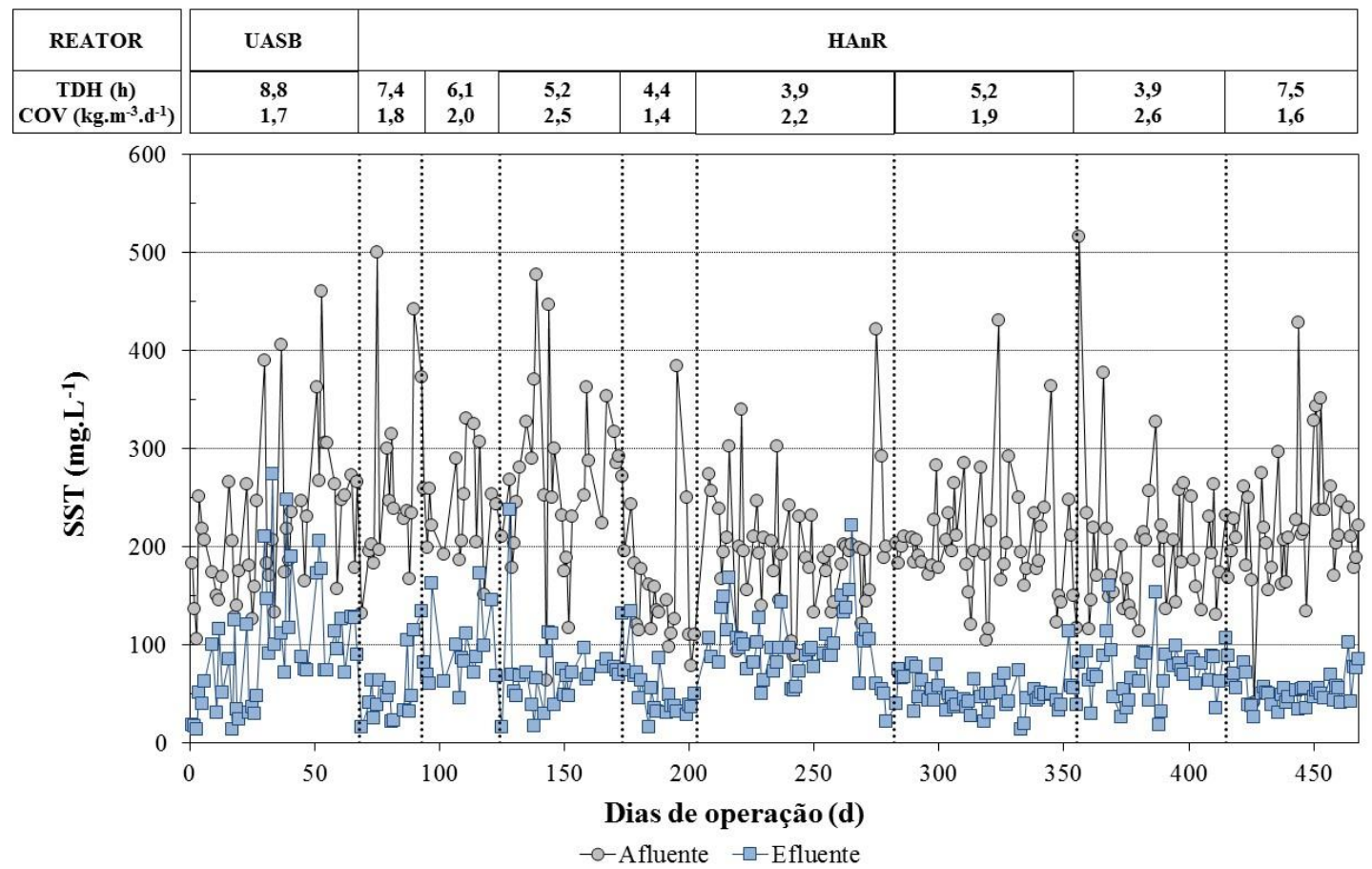

Figura 5.4 - Valores de SST afluente e efluente ao longo da operação do reator anaeróbio. 


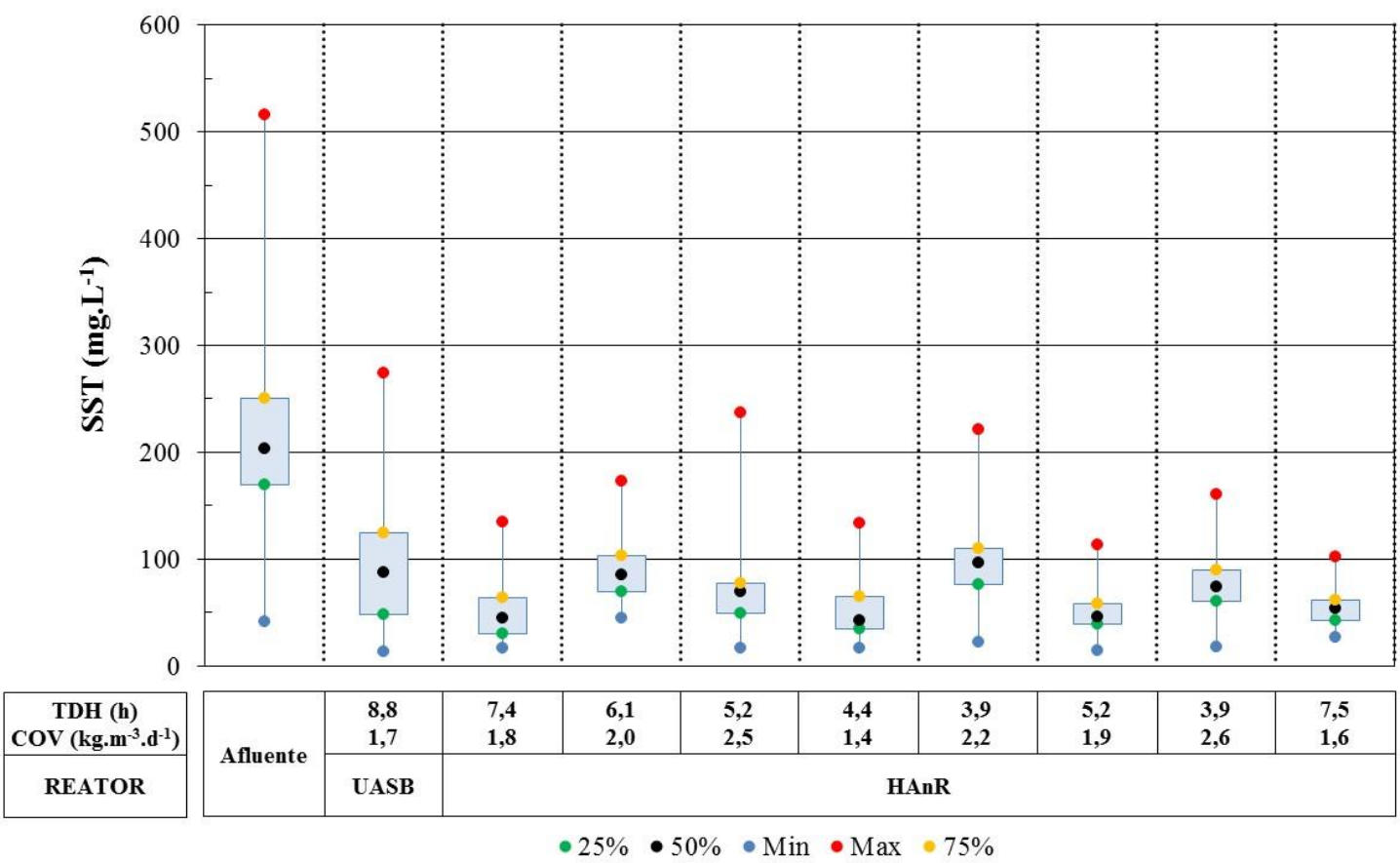

Figura 5.5 - Gráfico Box-plot de distribuição dos resultados de SST afluente e efluente para cada TDH aplicado ao longo da operação do reator anaeróbio.

Como evidenciado na Tabela 5.1, para todas as condições testadas, o HAnR apresentou desempenho satisfatório quanto a remoção de DQO e SST, quando comparado com outros sistemas anaeróbios aplicados ao tratamento de esgotos sanitários citados na literatura (METCALF \& EDDY, 2003), obtendo seu melhor desempenho para TDH igual a $7,4 \mathrm{~h}, \mathrm{v}_{\mathrm{s}}$ igual a $0,66 \mathrm{~m} \cdot \mathrm{h}^{-1}$ com $72 \pm 10 \%$ e $79 \pm 11 \%$ de eficiência na remoção de $\mathrm{DQO}_{\mathrm{t}}$ e SST, respectivamente. 
Tabela 5.1 - Resultados médios de DQO e SST afluente e efluente, eficiência de remoção de DQO e SST em função do tempo de detenção hidráulica (TDH), da velocidade ascensional aparente $\left(\mathrm{v}_{\mathrm{s}}\right)$ e da carga orgânica volumétrica (COV) aplicados.

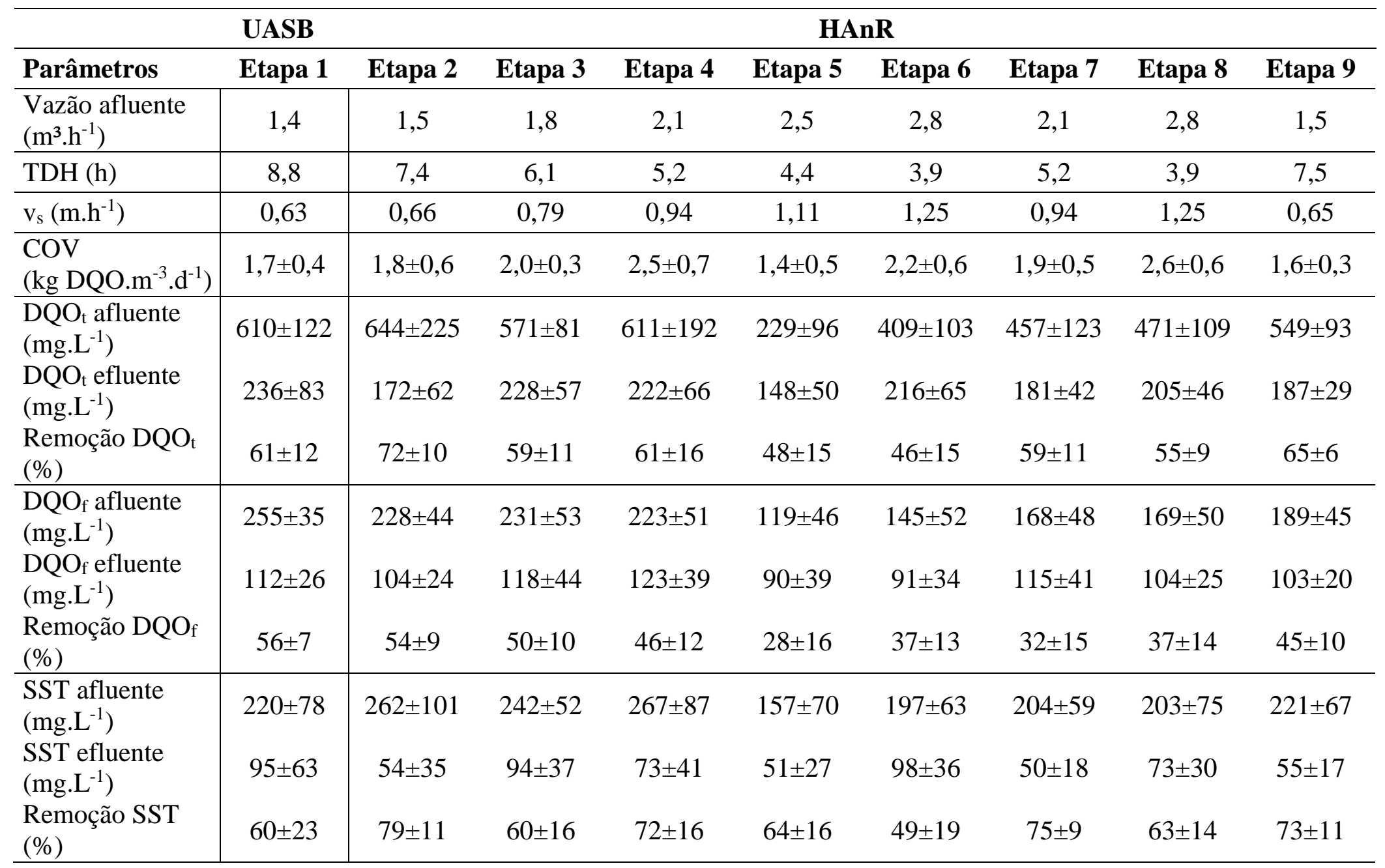


Na Tabela 5.2 são apresentados exemplos de aplicação de reatores anaeróbios no tratamento de esgotos sanitários e os resultados alcançados.

Tabela 5.2 - Parâmetros operacionais e desempenho de sistemas anaeróbios tratando esgotos sanitários.

\begin{tabular}{|c|c|c|c|c|c|c|}
\hline Referências & $\begin{array}{l}\text { Temp. } \\
\left({ }^{\circ} \mathrm{C}\right)\end{array}$ & $\begin{array}{c}\text { CHV } \\
\left(\mathbf{m}^{3} \cdot \mathbf{m}^{-3} \cdot \mathbf{d}^{-1}\right)\end{array}$ & $\begin{array}{c}\text { TDH } \\
\text { (h) }\end{array}$ & $\begin{array}{c}\mathbf{v s} \\
\left(\mathbf{m} \cdot h^{-1}\right)\end{array}$ & $\begin{array}{c}\text { EDQO } \\
(\%)\end{array}$ & $\begin{array}{l}\text { EsST } \\
(\%)\end{array}$ \\
\hline \multicolumn{7}{|c|}{ Reator anaeróbio de manta de lodo e escoamento ascendente (UASB) } \\
\hline $\begin{array}{l}\text { Lettinga et al. (1983) } \\
\text { de Man et al. (1988) apud }\end{array}$ & $8-20$ & 2,0 & 12,0 & 0,17 & $65-85$ & - \\
\hline Oliva, L.C.H.V. (1997) & $>20$ & 3,0 & 8,0 & 0,56 & $71-83$ & $71-85$ \\
\hline Florencio et al. (2001) & 30 & 2,5 & 9,7 & - & 67 & 61 \\
\hline von Sperling at al. (2001) & 30 & 6,0 & 4,0 & - & 85 & - \\
\hline Kalogo et al. (2001) & $25-35$ & 1,4 & 2,4 & 1,25 & 54 & 51 \\
\hline Aiyuk et al. (2004) & 33 & 2,4 & 10 & 1,00 & $55-60$ & - \\
\hline Leitão, R.C. (2004) & $12-20$ & 4,0 & 6,0 & 0,64 & 59 & 76 \\
\hline Carvalho, K.Q. (2006) & $20-25$ & 3,0 & 8,0 & 0,26 & 58 & - \\
\hline de Almeida et al. (2009) & $20-25$ & 3,1 & 7,7 & 0,59 & 65 & 70 \\
\hline
\end{tabular}

\section{Reator anaeróbio de leito fixo}

\begin{tabular}{l|c|c|c|c|c|c}
\hline Elmitwalli et al. (2002) & 13 & 6,0 & 4,0 & 0,53 & 81 & - \\
\hline Araujo Jr et al. (2013) & 26 & 6,7 & 3,0 & 0,56 & 65 & 69 \\
\hline
\end{tabular}

\section{Reator anaeróbio híbrido}

\begin{tabular}{l|c|c|c|c|c|c}
\hline Elmitwalli et al. (2002) $^{\mathrm{a}}$ & 13 & 3,0 & 8,0 & 0,29 & 64 & - \\
\hline Trabalho Atual $^{\mathrm{b}}$ & 27 & 5,5 & 3,9 & 1,25 & 55 & 63 \\
\hline
\end{tabular}

${ }^{a}$ Reatores utilizando espuma de poliuretano como material suporte para imobilização celular.

${ }^{\mathrm{b}}$ Reator utilizando Biobob® como meio suporte para imobilização celular.

${ }^{c}$ Dados extraídos de relatório técnico de planta piloto "Reatores de Leito Fixo Sequenciais Anaeróbio-Aeróbio Utilizando um Inovador Material Suporte no Tratamento de Esgotos

Sanitários”, desenvolvida e operada pela empresa Bio Proj Tecnologia Ambiental Ltda.

Como evidenciado nos gráficos da Figura 5.6 e Figura 5.7, para condições de operação similares, o reator HAnR, submetido a carga hidráulica volumétrica $(\mathrm{CHV})$ de $2,9 \pm 0,1 \mathrm{~m}^{3} \cdot \mathrm{m}^{-3} \cdot \mathrm{d}^{-1}$, apresentou melhor desempenho que o reator UASB, submetido a CHV de $2,7 \pm 0,2 \mathrm{~m}^{3} \cdot \mathrm{m}^{-3} \cdot \mathrm{d}^{-1}$, acrescendo em até $18 \%$ e $32 \%$ as eficiências de remoção de $\mathrm{DQO}_{\mathrm{t}}$ e SST, respectivamente. 


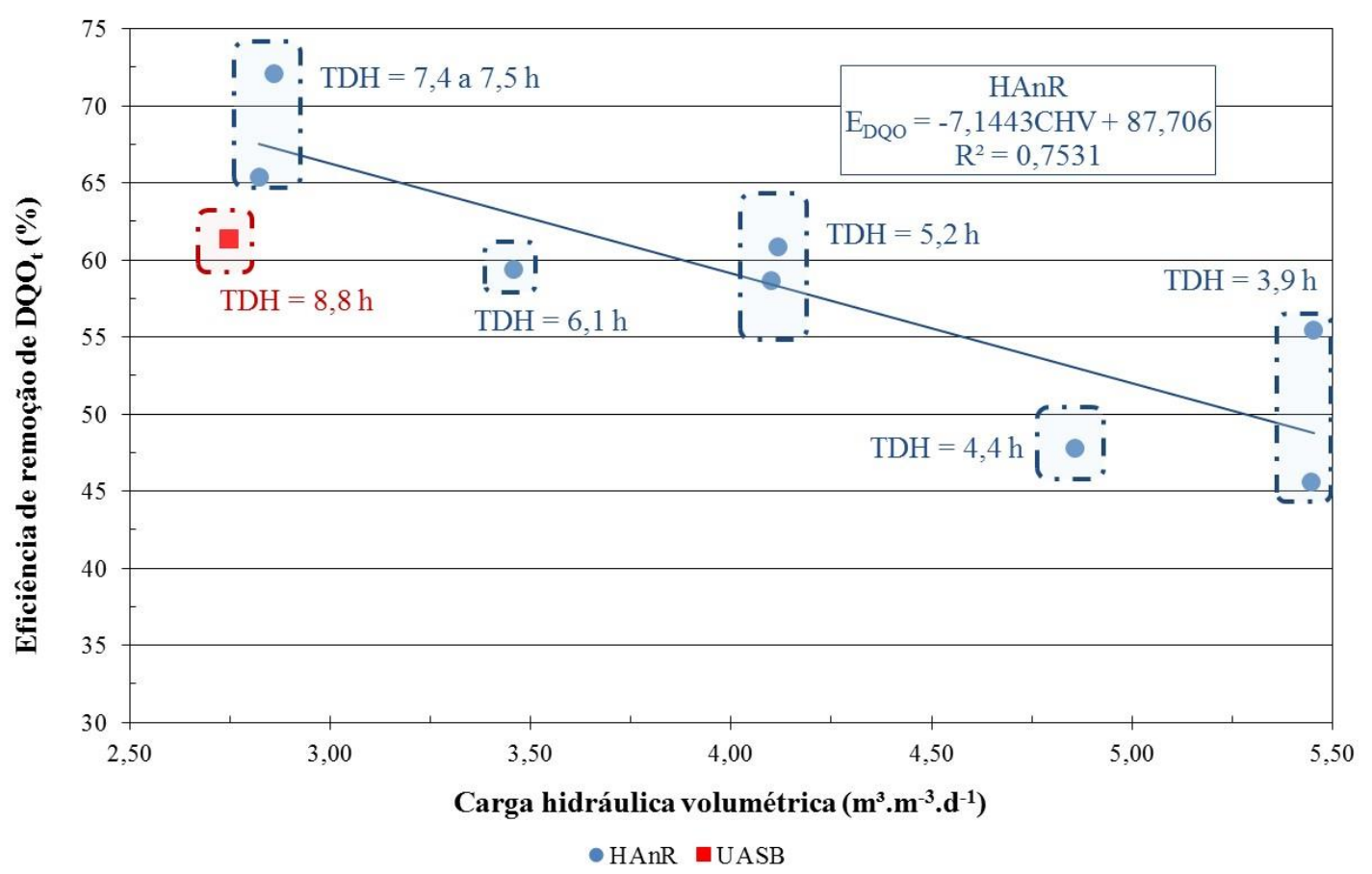

Figura 5.6 - Eficiência de remoção de $\mathrm{DQO}_{\mathrm{t}}$ em função da carga hidráulica volumétrica e TDH aplicados ao reator anaeróbio.

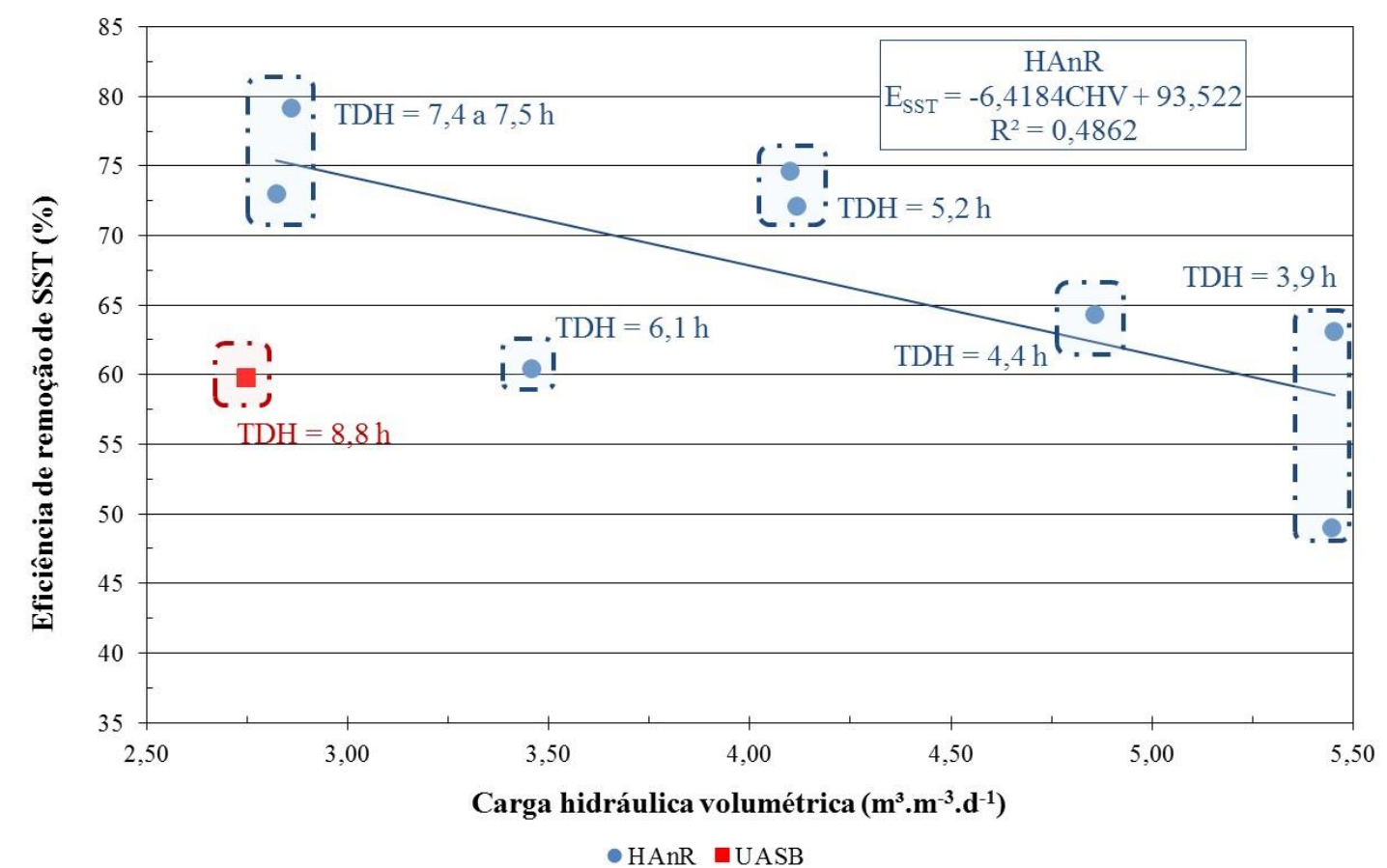

Figura 5.7 - Eficiência de remoção de SST em função da carga hidráulica volumétrica e TDH aplicados ao reator anaeróbio.

Embora o reator UASB, submetido à $\mathrm{v}_{\mathrm{s}}$ de $0,63 \pm 0,05 \mathrm{~m} \cdot \mathrm{h}^{-1}$ e TDH de $8,8 \pm 1,1 \mathrm{~h}$, tenha apresentado boa qualidade do efluente tratado com concentrações médias de

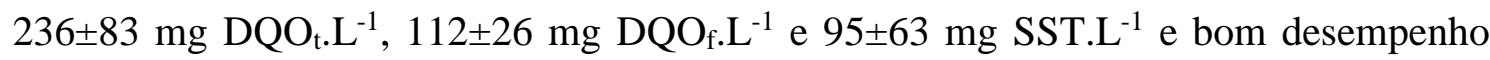

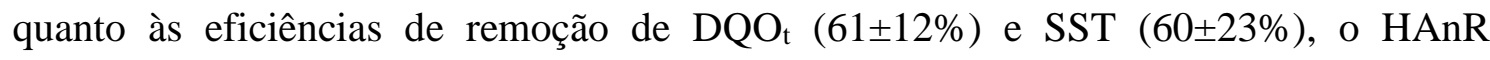


apresentou melhor qualidade do efluente tratado mesmo quando submetido a maiores velocidades ascensionais e menores TDH. Para a $\mathrm{v}_{\mathrm{s}}$ de $1,25 \pm 0,02 \mathrm{~m} \cdot \mathrm{h}^{-1}$ e TDH de 3,9 $\pm 0,1$ h, o HAnR apresentou concentrações médias no efluente tratado de $205 \pm 46 \mathrm{mg} \mathrm{DQO}$.. $\mathrm{L}^{-}$

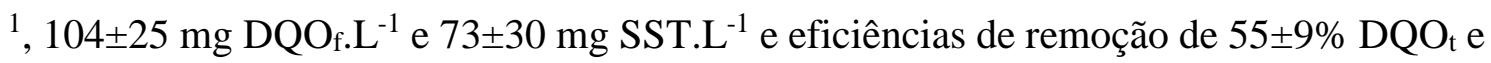
$63 \pm 14 \%$ SST.

Observou-se que não há uma tendência clara de piora da eficiência de remoção de DQO $_{\mathrm{t}}$ com o aumento da COV aplicada. Ou seja, para as condições testadas a COV não foi o fator determinante. Contudo, a variação do TDH teve grande impacto na eficiência de remoção de $\mathrm{DQO}_{\mathrm{t}}$, como pode ser evidenciado nos gráficos da Figura 5.8 e Figura 5.9, respectivamente.

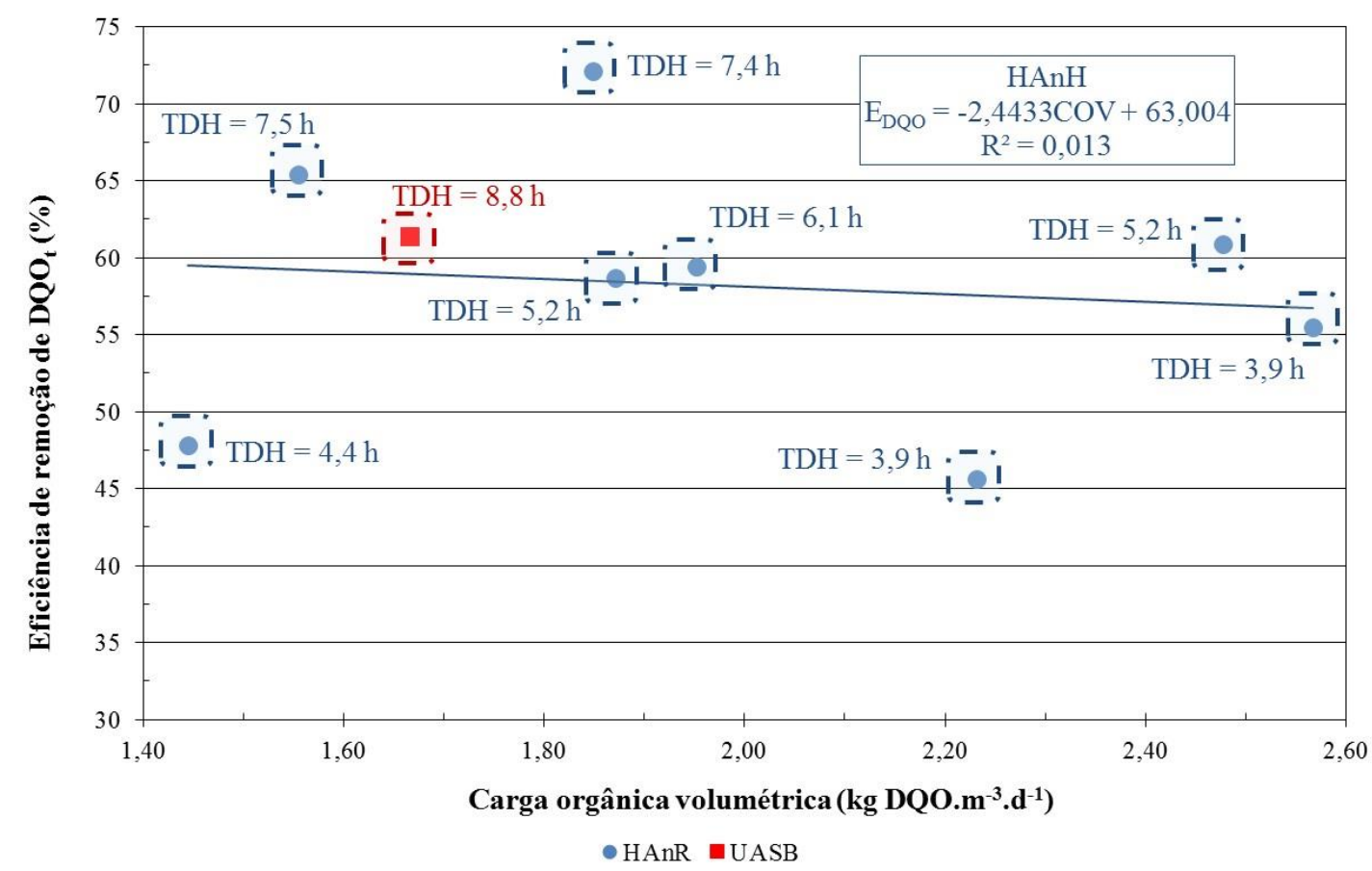

Figura 5.8 - Eficiência de remoção de $\mathrm{DQO}_{\mathrm{t}}$ em função da carga orgânica volumétrica aplicada. 


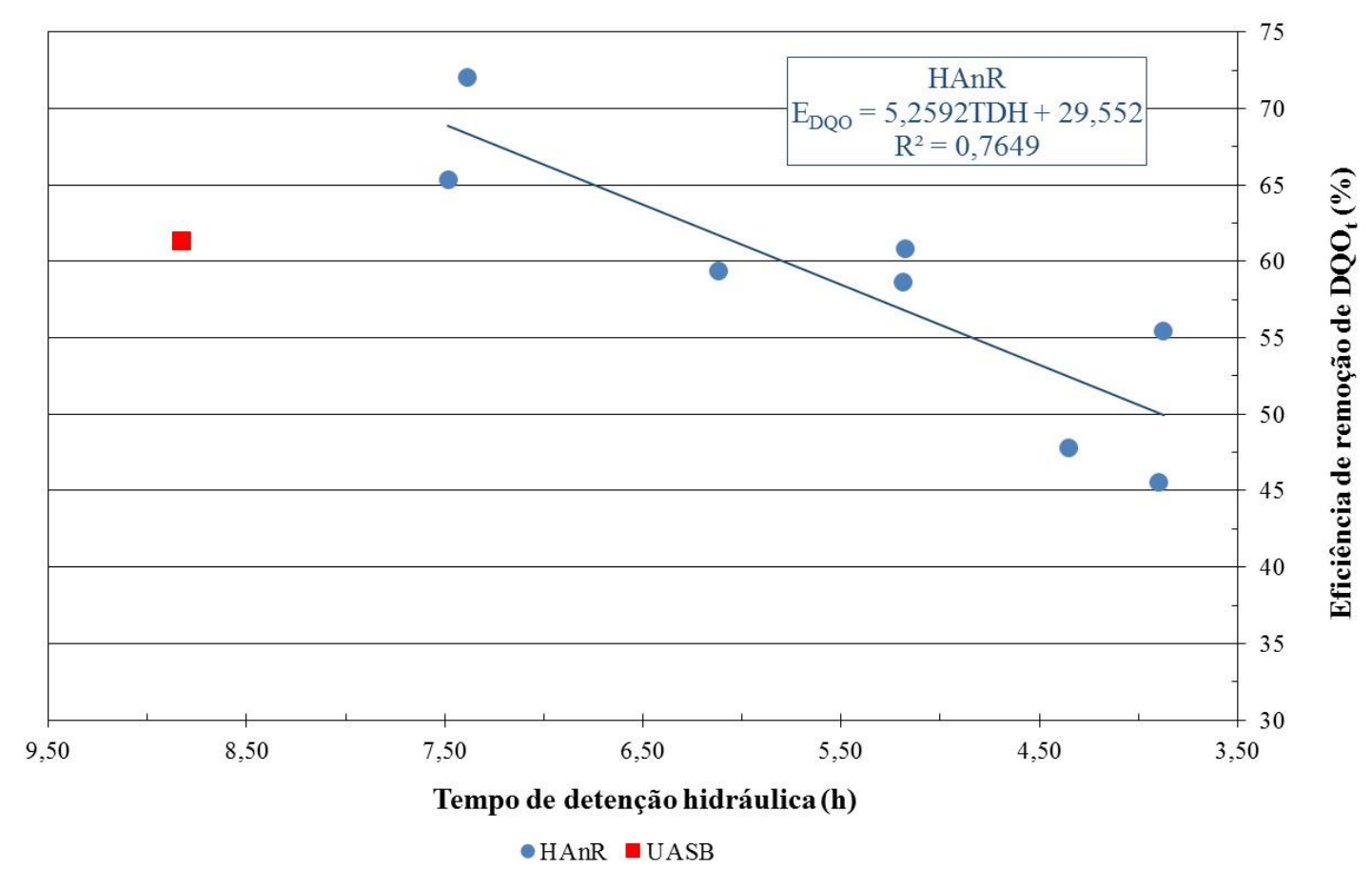

Figura 5.9 - Eficiência de remoção de $\mathrm{DQO}_{\mathrm{t}}$ em função do tempo de detenção hidráulica.

A eficiência na remoção de matéria orgânica do HAnR decresceu de $72 \pm 10 \%$ para $55 \pm 9 \%$ de remoção de $\mathrm{DQO}_{\mathrm{t}}$ quando o $\mathrm{TDH}$ decresceu de 7,4 h para 3,9 h, entretanto, conforme apresentado na Figura 5.10, a DQOt do efluente tratado apresentou

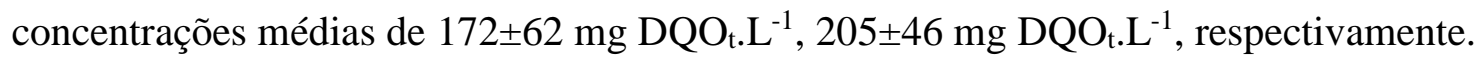

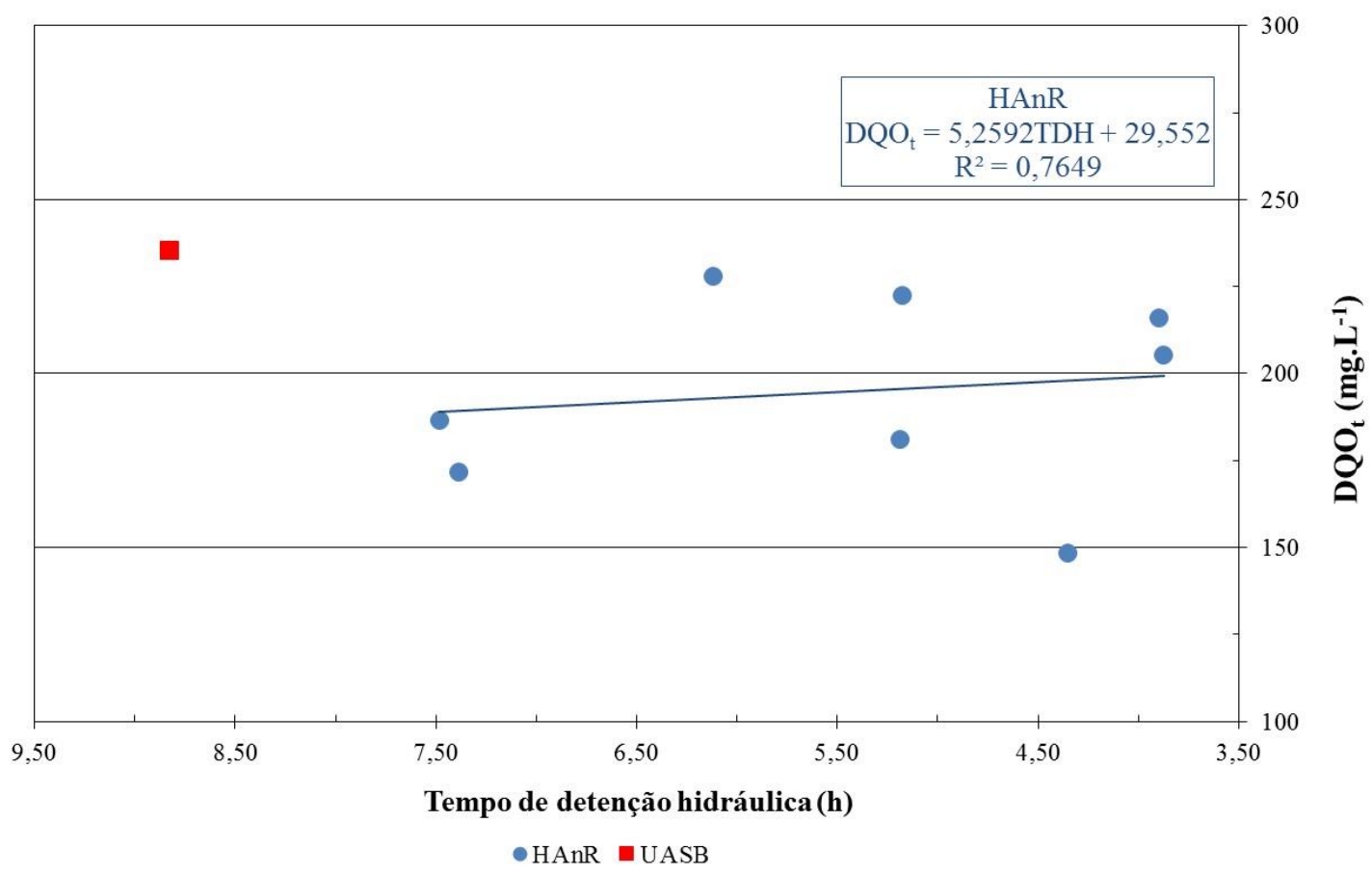

Figura 5.10 - Valores médios de $\mathrm{DQO}_{\mathrm{t}}$ no efluente em função do tempo de detenção hidráulica. 
O HAnR submetido ao TDH de 5,2 e velocidade ascensional aparente de 0,94 m.h ${ }^{1}$ apresentou eficiência na remoção de $\mathrm{DQO}_{\mathrm{t}}(61 \pm 16 \%)$ e concentração média no efluente

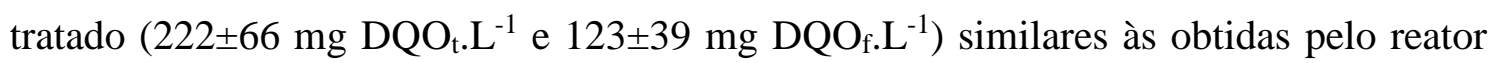
UASB, porém porém com uma CHV de $4,1 \mathrm{~m}^{3} \cdot \mathrm{m}^{-3} \cdot \mathrm{d}^{-1}, 52 \%$ maior do que a aplicada no reator UASB $\left(2,7 \mathrm{~m}^{3} \cdot \mathrm{m}^{-3} \cdot \mathrm{d}^{-1}\right)$ e com uma COV de $2,5 \mathrm{~kg}$ DQO. $\mathrm{m}^{-3} \cdot \mathrm{d}^{-1}, 47 \%$ maior do que a aplicada no reator UASB $\left(1,7 \mathrm{~kg}\right.$ DQO $\left.\mathrm{t}_{\mathrm{t}} \mathrm{m}^{-3} \cdot \mathrm{d}^{-1}\right)$.

Também, observou-se que a eficiência de remoção e a concentração no efluente de SST foi afetada pelas variações do TDH e da velocidade ascensional, como pode ser evidenciado nos gráficos da Figura 5.11, Figura 5.12 e Figura 5.13, respectivamente.

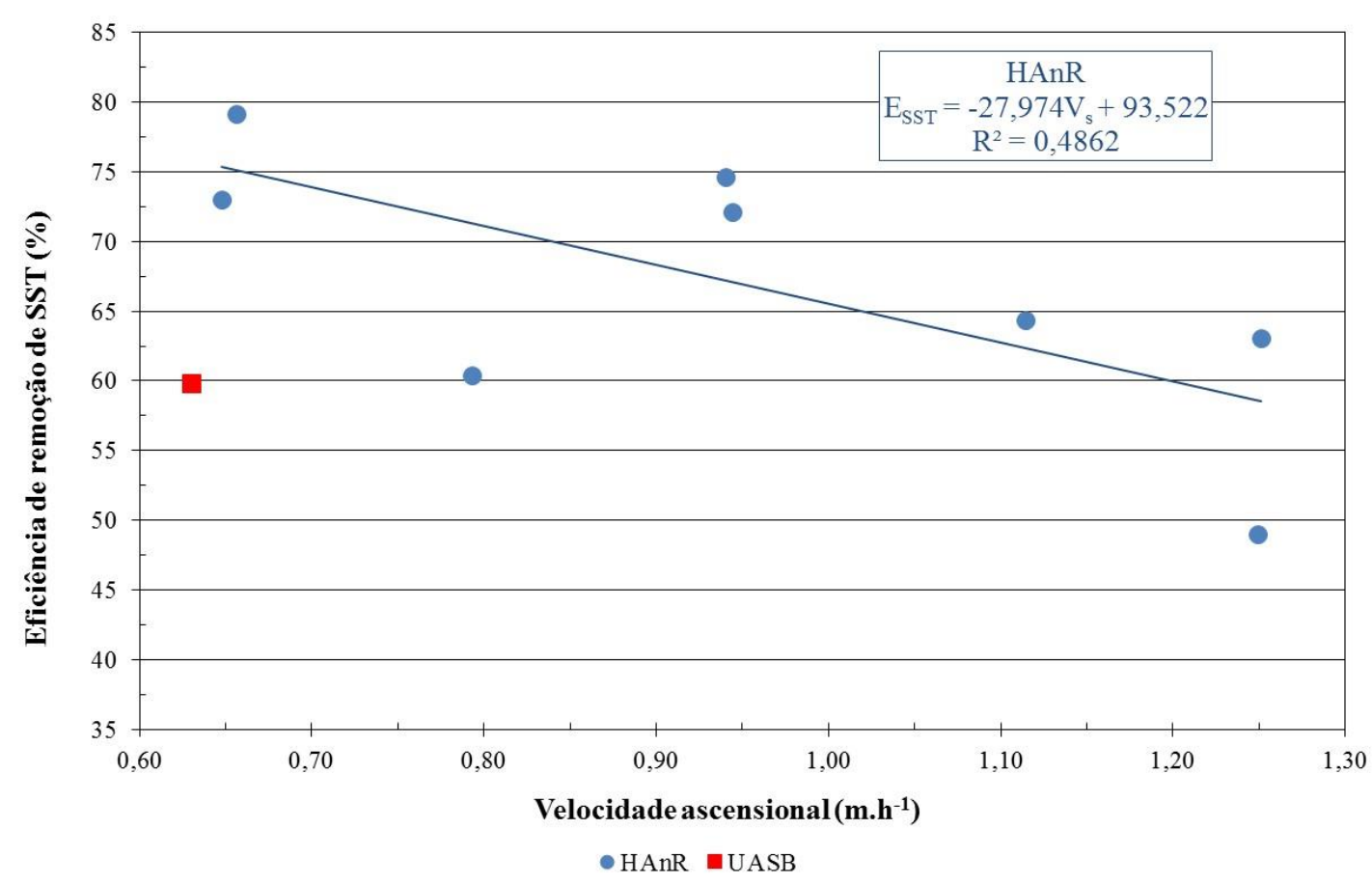

Figura 5.11 - Eficiência de remoção de SST em função da velocidade ascensional aplicada. 


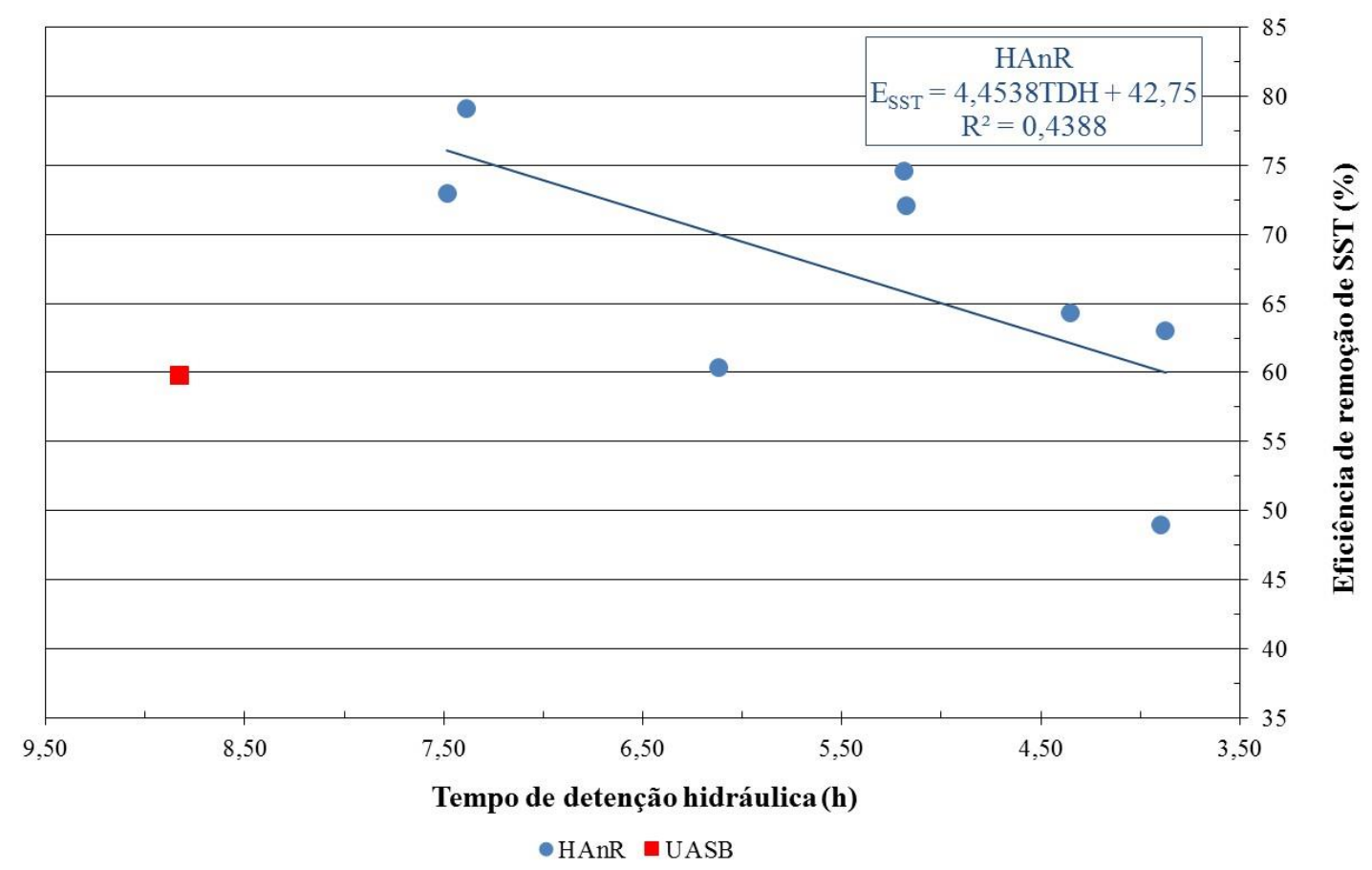

Figura 5.12 - Eficiência de remoção de SST em função do tempo de detenção hidráulica.

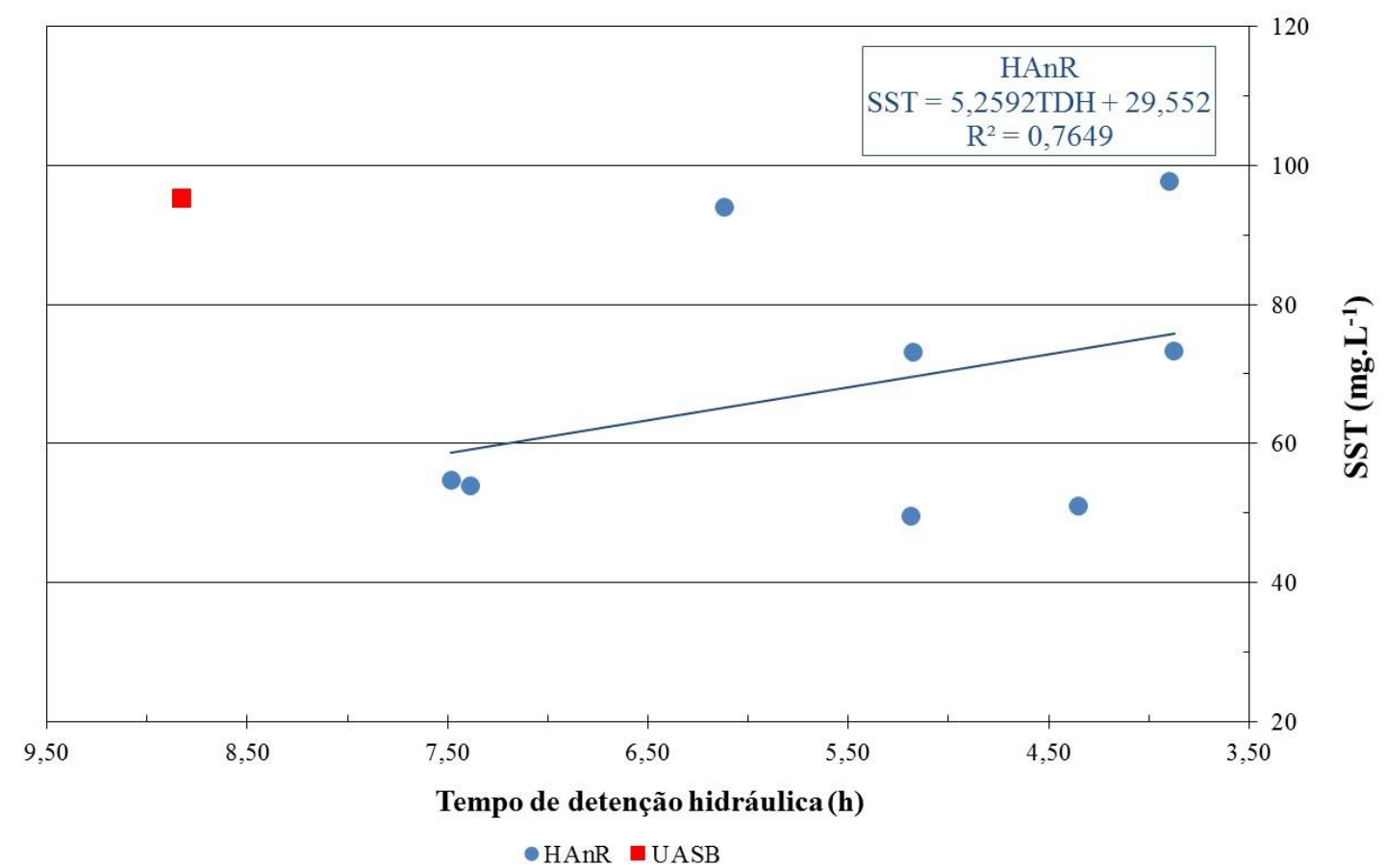

Figura 5.13 - Valores médios de SST no efluente em função do tempo de detenção hidráulica.

Para os valores de TDH de 7,4 a 3,9 h e para as velocidades ascensionais de 0,66 a $1,25 \mathrm{~m} \cdot \mathrm{h}^{-1}$, desconsiderando os resultados da sexta etapa, as eficiências de remoção de sólidos em suspensão totais, com valores médios entre 60 e 79\% SST, bem como as concentrações médias de SST no efluente $\left(54 \pm 35 \mathrm{mg} \mathrm{SST}^{-1} \mathrm{~L}^{-1}\right.$ a $\left.94 \pm 37 \mathrm{mg} \mathrm{SST.L^{-1 }}\right)$ foram 
superiores às apresentadas pelo reator UASB, que foram de $60 \%$ SST e $95 \pm 63$ mg SST.L ${ }^{-}$ 1.

O HAnR submetido a um TDH de 3,9 (oitava etapa), apresentou eficiência na remoção

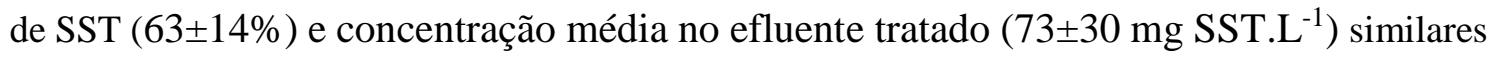
às obtidas pelo reator UASB, porém com velocidade ascensional aparente de $1,25 \mathrm{~m} \cdot \mathrm{h}^{-1}, 98 \%$ maior do que a aplicada no reator $\operatorname{UASB}\left(0,63 \mathrm{~m} \cdot \mathrm{h}^{-1}\right)$.

Na sexta etapa, em que o reator foi operado por um período de 79 dias, também

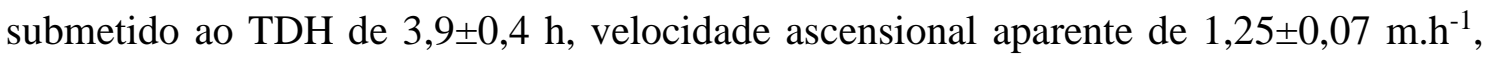
obteve-se concentração média de SST efluente de $98 \pm 36 \mathrm{mg} . \mathrm{L}^{-1}$. A baixa eficiência na remoção de SST, com valor médio na ordem de 49ะ19\%, foi devida ao escape de sólidos do leito reacional para o efluente tratado, ocasionado pelo excesso de lodo acumulado no reator.

Na Figura 5.14 são apresentados os dados de produção de metano, bem como a temperatura do esgoto sanitário afluente ao longo da operação do reator anaeróbio. Os valores médios da produção de metano nas condições normais de temperatura e pressão (CNTP), o volume de biogás e temperatura do esgoto sanitário afluente para cada TDH e COV são apresentados na Tabela 5.3.

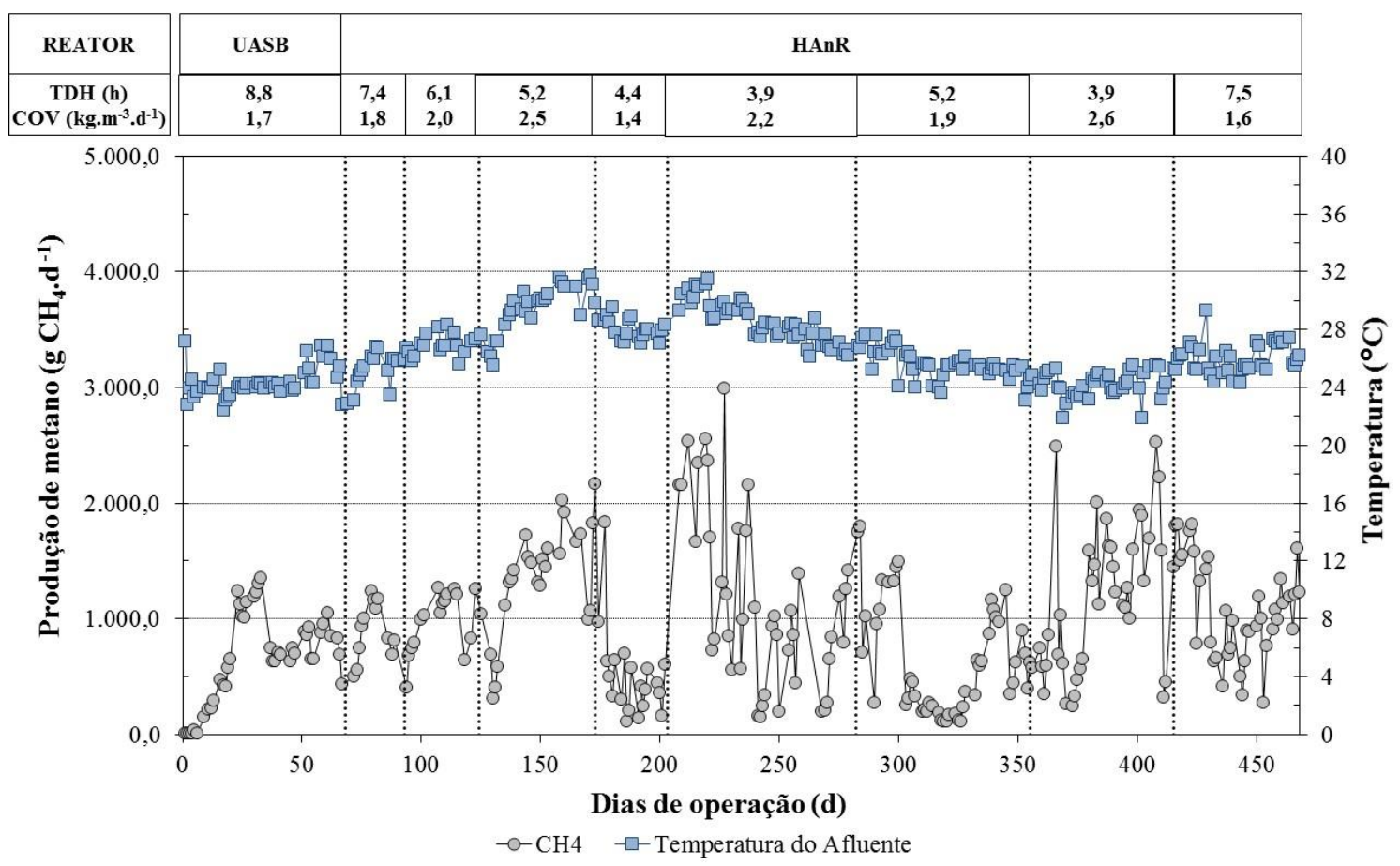

Figura 5.14 - Valores da produção de metano e temperatura do esgoto sanitário afluente ao longo da operação do reator anaeróbio. 
Tabela 5.3 - Os valores médios da produção de metano na CNTP, do volume de biogás e temperatura do esgoto sanitário afluente para cada TDH e COV.

\begin{tabular}{|c|c|c|c|c|c|c|c|c|c|}
\hline \multicolumn{5}{|c|}{ UASB } & \multicolumn{3}{|c|}{ HAnR } & \multirow[b]{2}{*}{3,9} & \multirow[b]{2}{*}{7,5} \\
\hline TDH (h) & 8,8 & 7,4 & 6,1 & 5,2 & 4,4 & 3,9 & 5,2 & & \\
\hline $\begin{array}{l}\text { COV } \\
\left(\mathrm{kg} \mathrm{DQO} \cdot \mathrm{m}^{-3} \cdot \mathrm{d}^{-1}\right)\end{array}$ & $\begin{array}{c}1,7 \pm \\
0,4\end{array}$ & $\begin{array}{c}1,8 \pm \\
0,6\end{array}$ & $\begin{array}{c}2,0 \pm \\
0,3\end{array}$ & $\begin{array}{c}2,5 \pm \\
0,7\end{array}$ & $\begin{array}{c}1,4 \pm \\
0,5\end{array}$ & $\begin{array}{c}2,2 \pm \\
0,6\end{array}$ & $\begin{array}{c}1,9 \pm \\
0,5\end{array}$ & $\begin{array}{c}2,6 \pm \\
0,6\end{array}$ & $\begin{array}{c}1,6 \pm \\
0,3\end{array}$ \\
\hline $\begin{array}{l}\text { Temperatura } \\
\text { afluente }\left({ }^{\circ} \mathrm{C}\right)\end{array}$ & $24 \pm 1$ & $25 \pm 1$ & $27 \pm 1$ & $29 \pm 2$ & $28 \pm 1$ & $29 \pm 1$ & $26 \pm 1$ & $24 \pm 1$ & $26 \pm 1$ \\
\hline $\begin{array}{l}\text { Volume Biogás } \\
\left(\mathrm{m}^{3} \cdot \mathrm{d}^{-1}\right)\end{array}$ & $\begin{array}{c}1,0 \pm \\
0,6 \\
\end{array}$ & $\begin{array}{c}1,4 \pm \\
0,4\end{array}$ & $\begin{array}{c}1,5 \pm \\
0,4\end{array}$ & $\begin{array}{c}2,1 \pm \\
0,7\end{array}$ & $\begin{array}{c}0,8 \pm \\
0,6\end{array}$ & $\begin{array}{c}1,8 \pm \\
1,2 \\
\end{array}$ & $\begin{array}{c}1,0 \pm \\
0,7\end{array}$ & $\begin{array}{c}1,8 \pm \\
1,0\end{array}$ & $\begin{array}{c}1,7 \pm \\
0,6 \\
\end{array}$ \\
\hline $\begin{array}{l}\text { Produção de } \\
\text { Metano }\left(\mathrm{kg} \cdot \mathrm{d}^{-1}\right)\end{array}$ & $\begin{array}{c}0,7 \pm \\
0,4\end{array}$ & $\begin{array}{c}0,9 \pm \\
0,2\end{array}$ & $\begin{array}{c}1,0 \pm \\
0,3\end{array}$ & $\begin{array}{c}1,3 \pm \\
0,5\end{array}$ & $\begin{array}{c}0,5 \pm \\
0,4\end{array}$ & $\begin{array}{c}1,2 \pm \\
0,8\end{array}$ & $\begin{array}{c}0,6 \pm \\
0,5\end{array}$ & $\begin{array}{c}1,2 \pm \\
0,6\end{array}$ & $\begin{array}{c}1,1 \pm \\
0,4 \\
\end{array}$ \\
\hline
\end{tabular}

Observou-se que o aumento da produção de metano foi acompanhada pelo aumento da temperatura do esgoto afluente bem como pelo aumento da COV aplicada ao

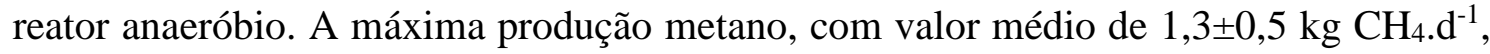
ocorreu para as condições de temperatura do esgoto afluente igual a $29^{\circ} \mathrm{C}, \mathrm{COV}$ de 2,5 $\mathrm{kg}$ DQO $_{\mathrm{t}} \cdot \mathrm{m}^{-3} \cdot \mathrm{d}^{-1}$ e TDH de $5,2 \mathrm{~h}$.

Acredita-se que a composição do biogás foi predominantemente de $\mathrm{CH}_{4}$ em todas as etapas operacionais devido à manutenção do $\mathrm{pH}$ em valor superior a 10 na solução de hidróxido de sódio $(\mathrm{NaOH})$ do selo hídrico (Figura 5.15), removendo assim do biogás o $\mathrm{H}_{2} \mathrm{~S}\left(\mathrm{pKa} \mathrm{HS}{ }^{-}=7,0\right.$ a $\left.25^{\circ} \mathrm{C}\right)$ e o $\mathrm{CO}_{2}\left({\mathrm{pKa} \mathrm{HCO}_{3}}^{-}=6,4\right.$ a $\left.25^{\circ} \mathrm{C}\right)$, formando os sais de sulfeto de sódio $\left(\mathrm{Na}_{2} \mathrm{~S}\right)$ e bicarbonato de sódio $\left(\mathrm{NaHCO}_{3}\right)$, respectivamente.

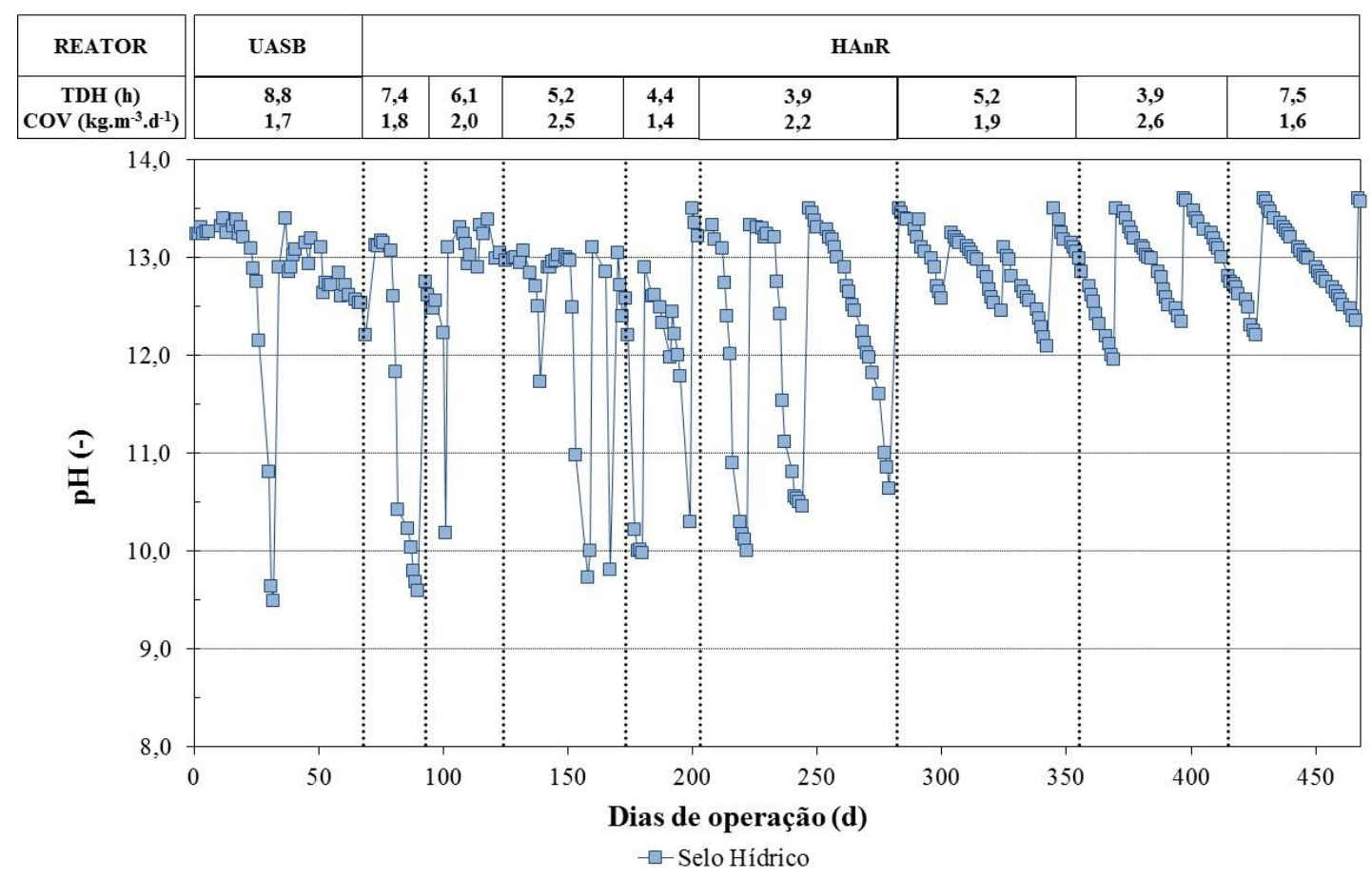

Figura 5.15 - Valores de pH do selo hídrico ao longo da operação do reator anaeróbio. 
Com a diminuição do TDH e o aumento da COV aplicada, houve aumento da remoção de DQO e consequente aumento na produção de biogás. Contudo, como esperado, a relação $\mathrm{CH}_{4}$. DQO removida $^{-1}$ não se alterou significativamente ao longo da operação do HAnR, mantendo-se com valor médio de $31 \%$ do valor máximo estequiométrico (250 g. $\mathrm{kg}^{-1} \mathrm{DQO}_{\mathrm{t} \text { removida }}$ ), como mostrado na Figura 5.16. Outros autores mostraram evidências que, no tratamento de águas com baixas concentrações de matéria orgânica, como esgoto sanitário, uma quantidade substancial do metano produzido encontra-se dissolvido no efluente (SINGH et al., 1996; UEMURA \& HARADA, 2000; AIYUK et al., 2004).

Para Singh et al. (1996), a quantidade relativamente baixa de $\mathrm{CH} 4$ produzido comparada com a DQO removida (40\% em relação ao valor teórico) pode ser atribuída também à ocorrência de reações de redução de sulfato e à supersaturação do CH4 no líquido. Isto implica que o tratamento de esgotos sanitários reduz a vantagem intrínseca de um processo anaeróbio como um sistema de recuperação de energia.

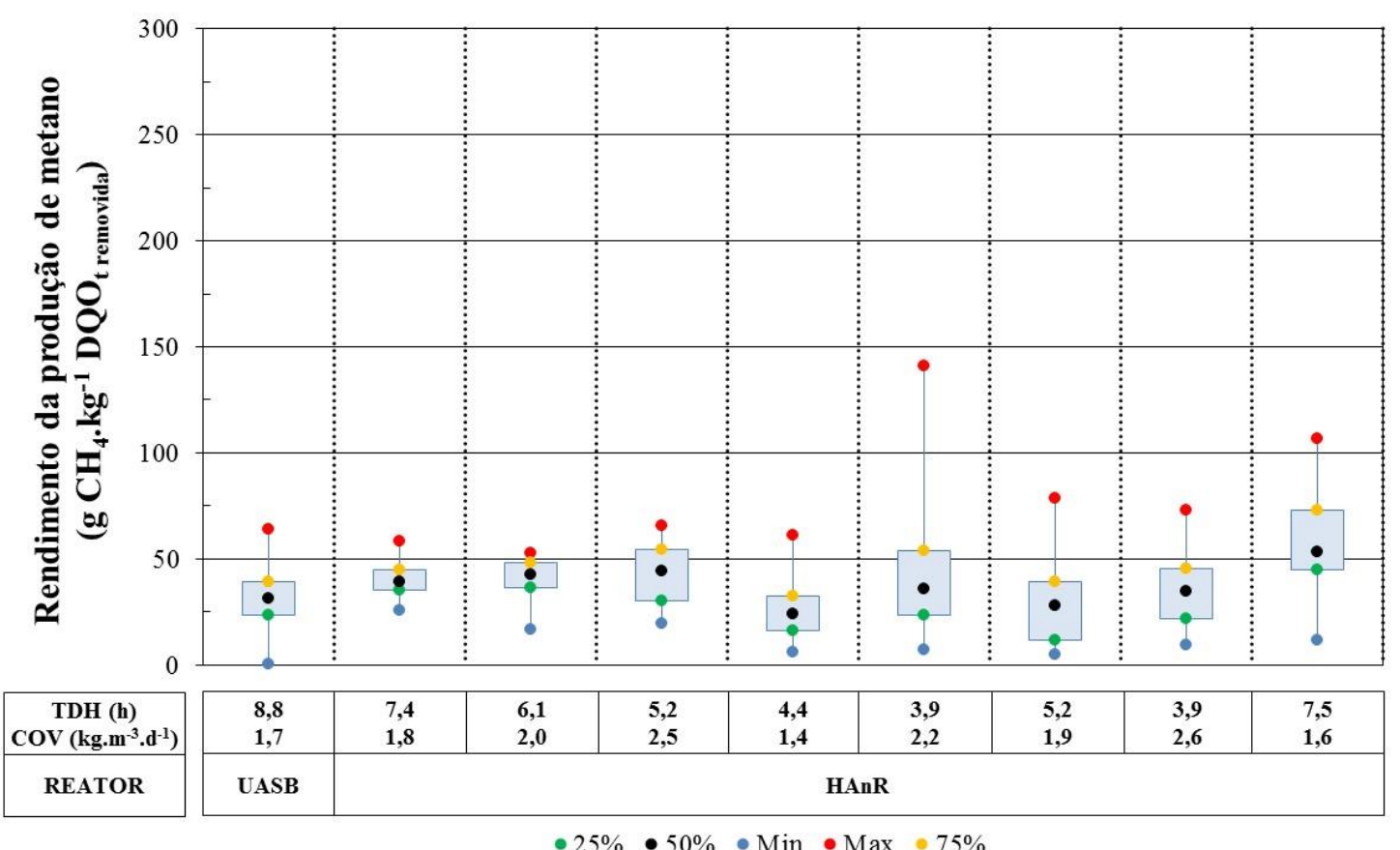

Figura 5.16 - Gráfico Box-plot de distribuição dos resultados de rendimento da produção de metano ao longo da operação do reator anaeróbio.

Conforme apresentado na Figura 5.17, a concentração de ácidos voláteis totais (AVT) no afluente do reator anaeróbio não apresentou grande variação ao longo da

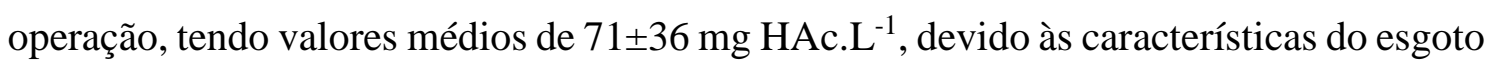
sanitário estudado. Independentemente da COV e do TDH aplicados ao HAnR, em todas as etapas, houve consumo de ácidos orgânicos, com concentração média no efluente 
tratado de $42 \pm 16$ mg HAc. $\mathrm{L}^{-1}$, evidenciando a predominância da atividade metanogênica.

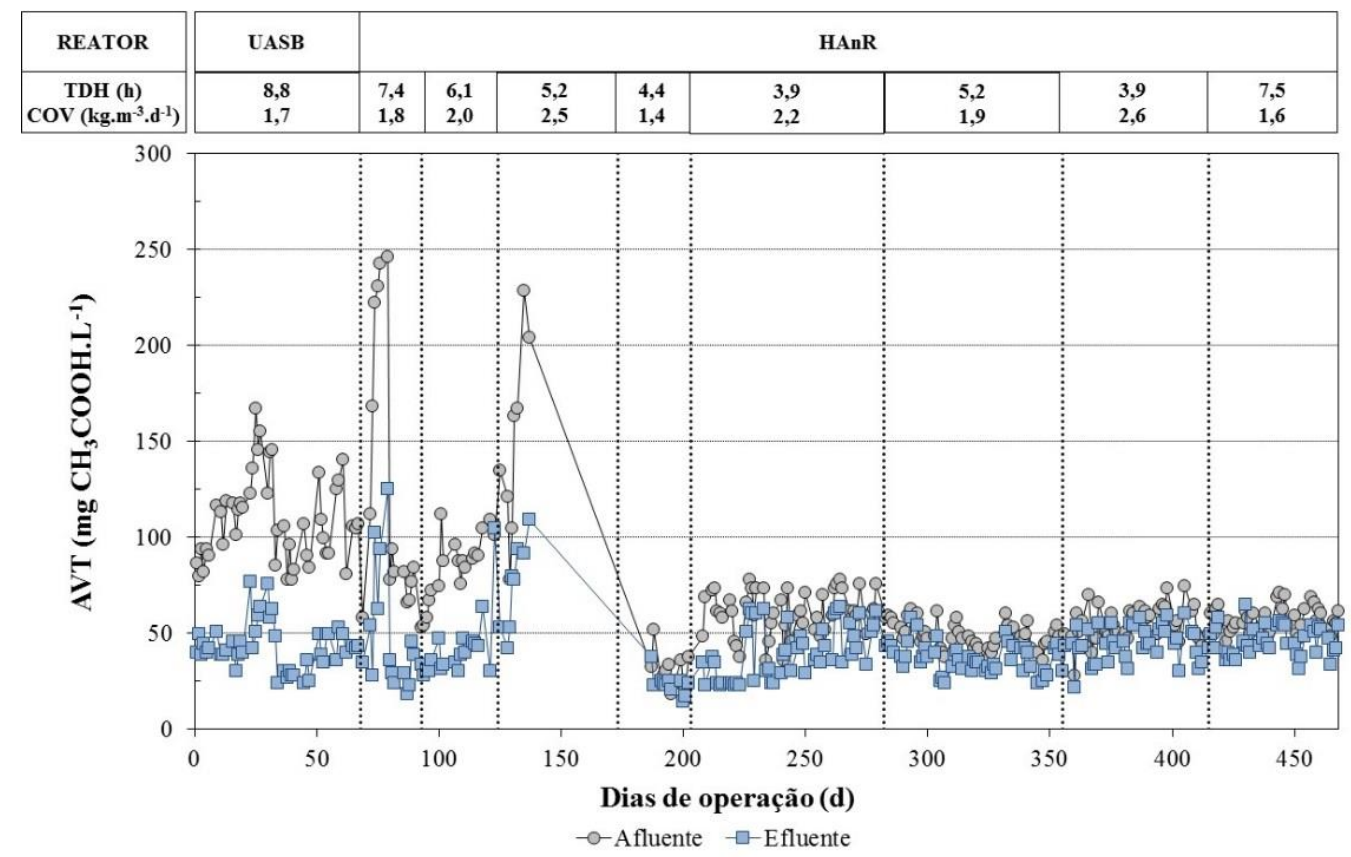

Figura 5.17 - Valores de AVT afluente e efluente ao longo da operação do reator anaeróbio.

Observou-se que os valores de alcalinidade a bicarbonato $(\mathrm{AB})$ no efluente, tendo valores médios de $255 \pm 32 \mathrm{mg} \mathrm{CaCO}_{3} \cdot \mathrm{L}^{-1}$, foram superiores àqueles obtidos no afluente, tendo valores médios de $214 \pm 36 \mathrm{mg} \mathrm{CaCO}_{3} \cdot \mathrm{L}^{-1}$, durante todo o período de operação do reator anaeróbio, indicando o "equilíbrio" entre os microrganismos acidogênicos e metanogênicos, além de indicar a capacidade do sistema de tamponar o meio, como pode ser evidenciado no gráfico da Figura 5.18.

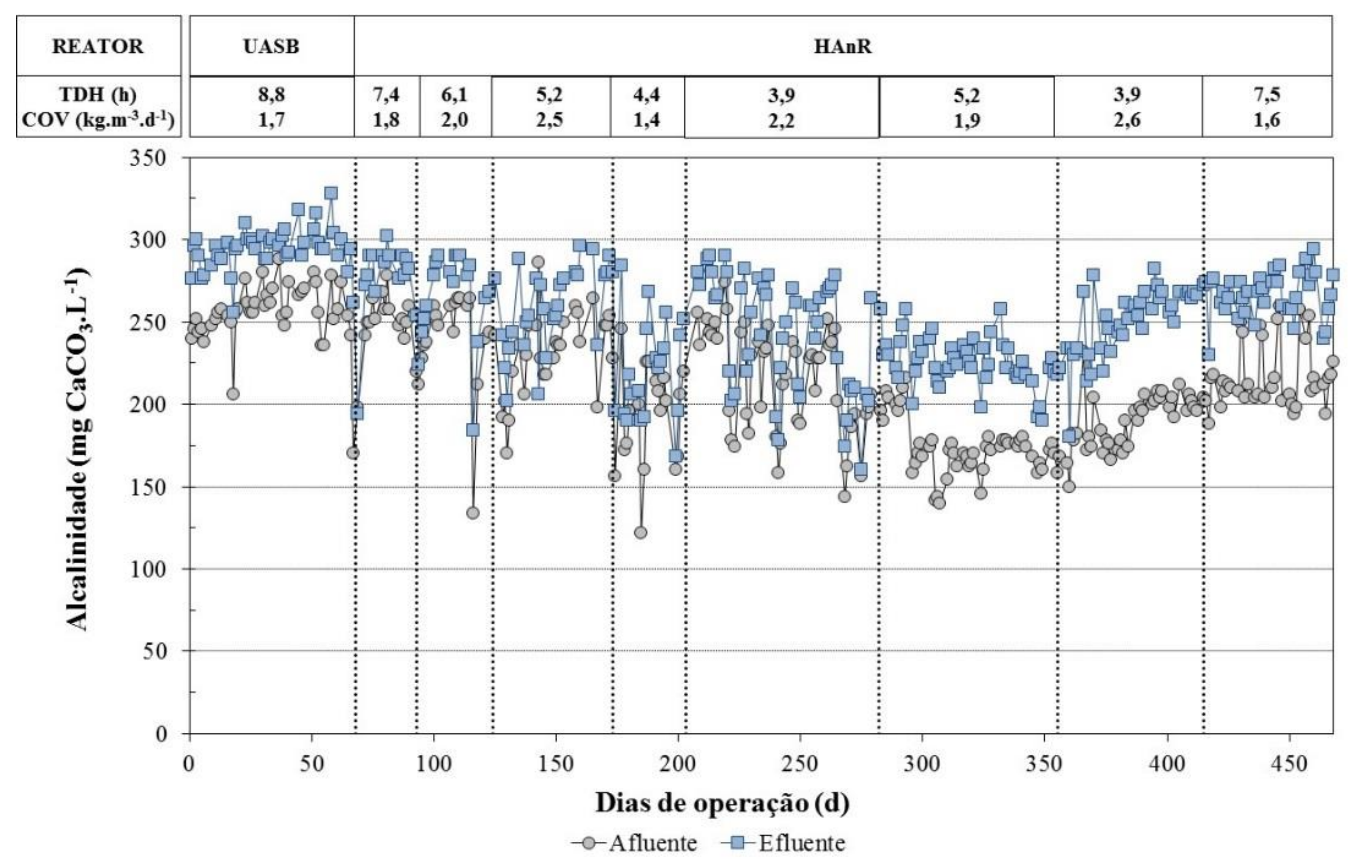

Figura 5.18 - Valores de AB afluente e efluente ao longo da operação do reator. 
Os valores de $\mathrm{pH}$ variaram de 6,9 a 7,9 no afluente e de 6,9 a 8,1 no efluente durante todo o período de operação do reator anaeróbio. Segundo Speece (1983), os resultados obtidos para o $\mathrm{pH}$ afluente estão em faixa recomendada para a digestão anaeróbia, como pode ser evidenciado no gráfico da Figura 5.19.

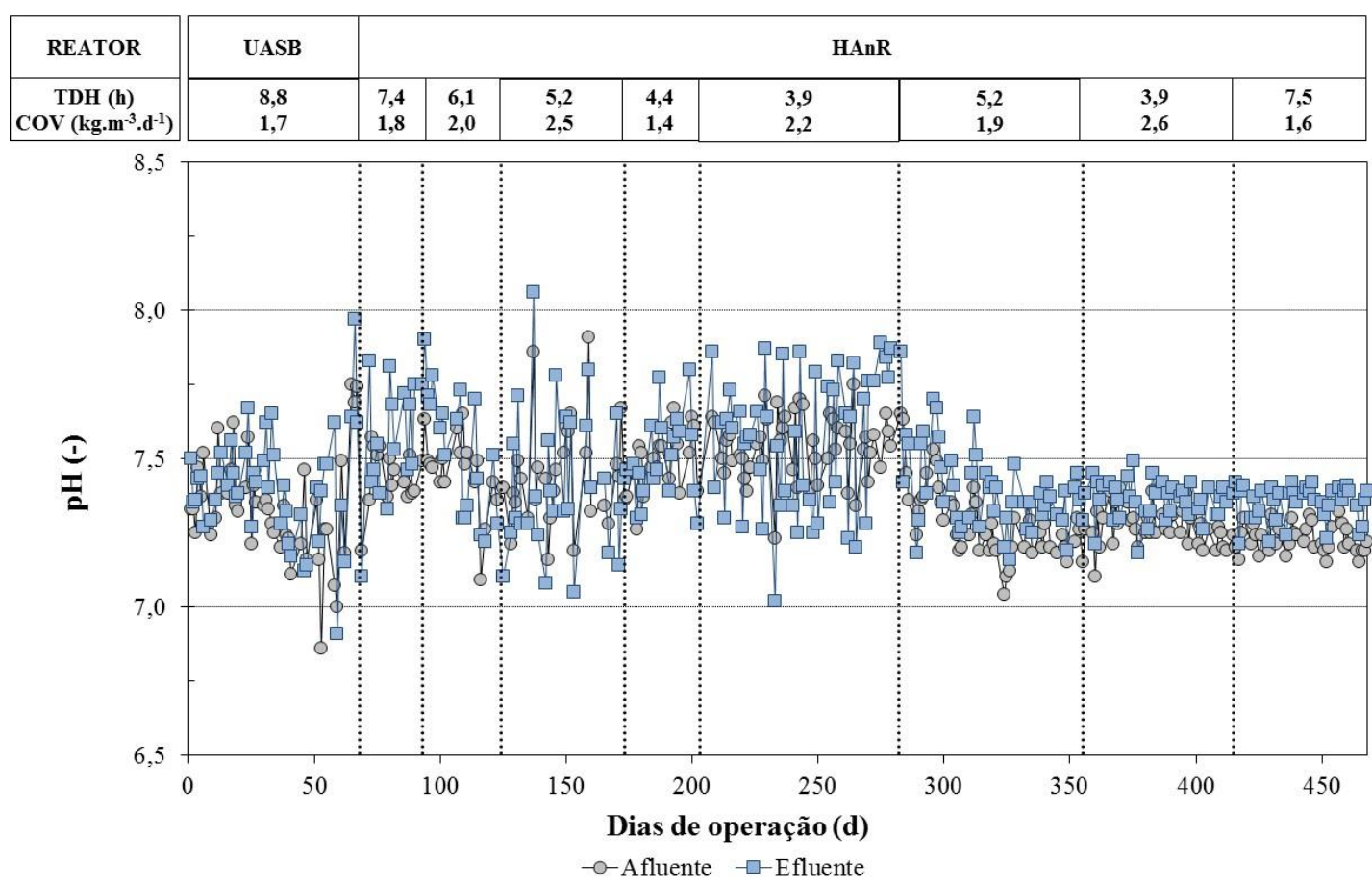

Figura 5.19 - Perfil de pH afluente e efluente ao longo da operação do reator anaeróbio.

A concentração média de nitrogênio total (NT) na alimentação do HAnR foi de $51 \pm 13$ mg N.L ${ }^{-1}$, sendo $27 \%$ na forma orgânica (N-org) e $73 \%$ na forma amoniacal (Namoniacal). Após o tratamento anaeróbio, a fração de nitrogênio na forma amoniacal aumentou para $90 \%$, com valor médio de $47 \pm 10 \mathrm{mg} \mathrm{N} . \mathrm{L}^{-1}$, enquanto que a concentração de nitrogênio orgânico apresentou-se baixa, com valor médio de $6 \pm 5 \mathrm{mg} \mathrm{N}$. $\mathrm{L}^{-1}$. Na Figura 5.20 é apresentada a variação da concentração de nitrogênio total no afluente e efluente e amoniacal no efluente tratado do reator anaeróbio ao longo da operação. 


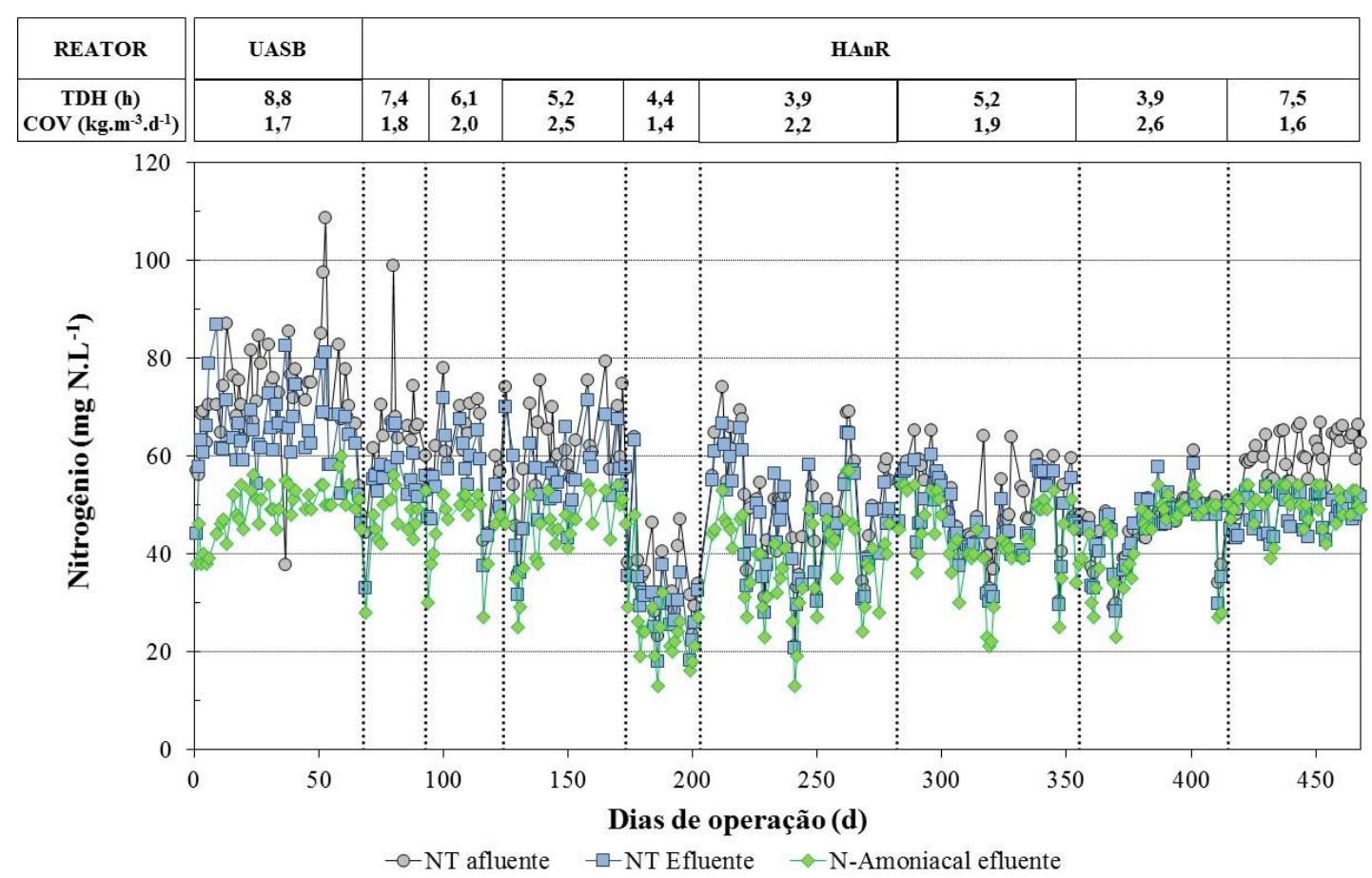

Figura 5.20 - Perfil de nitrogênio total e amoniacal no afluente e efluente ao longo da operação do reator anaeróbio.

Durante toda a operação do HAnR por 399 dias consecutivos, não observou-se aumento da perda de carga no leito reacional, evidenciando que não houve acumulo de sólidos nos interstícios e colmatação do leito. Também não observou-se a formação de escuma na câmara de separação de biogás.

Para efeito ilustrativo, na Figura 5.21 são apresentadas as fotos do afluente e efluente do HAnR, após ter alcançado o estado de equilíbrio dinâmico aparente (Etapa 2).

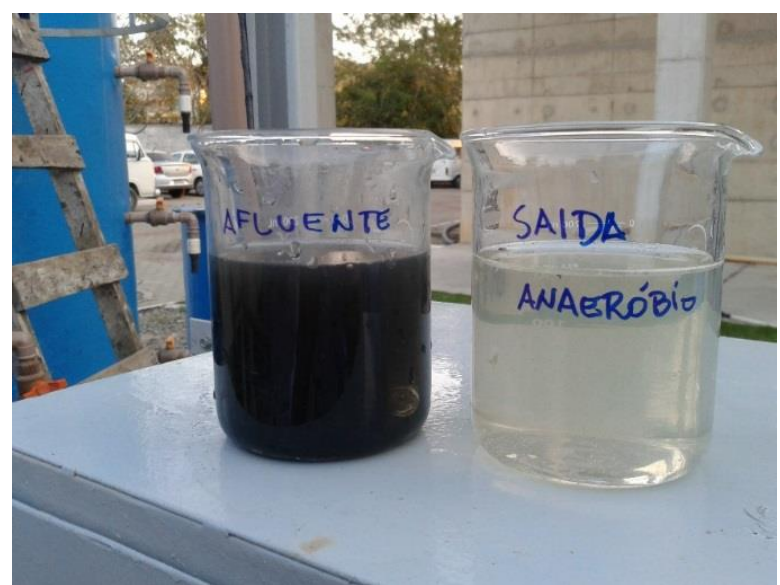

AFLUENTE

EFLUENTE

Figura 5.21 - Fotos do afluente e efluente do HAnR.

Os resultados médios de todos os parâmetros analisados durante a operação do reator anaeróbio são apresentados na Tabela 5.4. 
Tabela 5.4 - Resultados médios dos parâmetros analisados durante a operação do reator anaeróbio.

\begin{tabular}{|c|c|c|c|c|c|c|c|c|c|}
\hline & UASB & & & & & $\mathbf{n R}$ & & & \\
\hline Parâmetros & Etapa 1 & Etapa 2 & Etapa 3 & Etapa 4 & Etapa 5 & Etapa 6 & Etapa 7 & Etapa 8 & Etapa 9 \\
\hline TDH (h) & 8,8 & 7,4 & 6,1 & 5,2 & 4,4 & 3,9 & 5,2 & 3,9 & 7,5 \\
\hline $\begin{array}{l}\text { Temperatura afluente } \\
\left({ }^{\circ} \mathrm{C}\right)\end{array}$ & $24 \pm 1$ & $25 \pm 1$ & $27 \pm 1$ & $29 \pm 2$ & $28 \pm 1$ & $29 \pm 1$ & $26 \pm 1$ & $24 \pm 1$ & $26 \pm 1$ \\
\hline $\begin{array}{l}\text { Temperatura efluente } \\
\left({ }^{\circ} \mathrm{C}\right)\end{array}$ & $24 \pm 1$ & $25 \pm 1$ & $27 \pm 1$ & $29 \pm 2$ & $28 \pm 1$ & $29 \pm 1$ & $26 \pm 1$ & $24 \pm 1$ & $26 \pm 1$ \\
\hline pH afluente & $7,3 \pm 0,2$ & $7,4 \pm 0,1$ & $7,5 \pm 0,1$ & $7,4 \pm 0,2$ & $7,5 \pm 0,1$ & $7,5 \pm 0,1$ & $7,3 \pm 0,1$ & $7,3 \pm 0,1$ & $7,2 \pm 0,0$ \\
\hline pH efluente & $7,4 \pm 0,2$ & $7,6 \pm 0,2$ & $7,5 \pm 0,2$ & $7,4 \pm 0,2$ & $7,5 \pm 0,1$ & $7,6 \pm 0,2$ & $7,4 \pm 0,1$ & $7,4 \pm 0,1$ & $7,4 \pm 0,1$ \\
\hline $\begin{array}{l}\mathrm{AB}^{\mathrm{a}} \text { afluente } \\
\left(\mathrm{mg} \mathrm{CaCO}_{3} \cdot \mathrm{L}^{-1}\right)\end{array}$ & $255 \pm 20$ & $249 \pm 19$ & $240 \pm 31$ & $232 \pm 25$ & $193 \pm 30$ & $215 \pm 31$ & $174 \pm 17$ & $189 \pm 17$ & $217 \pm 20$ \\
\hline $\begin{array}{l}\mathrm{AB}^{\mathrm{a}} \text { efluente } \\
\left(\mathrm{mg} \mathrm{CaCO}_{3} \cdot \mathrm{L}^{-1}\right)\end{array}$ & $294 \pm 13$ & $227 \pm 25$ & $265 \pm 28$ & $259 \pm 26$ & $221 \pm 30$ & $243 \pm 35$ & $226 \pm 15$ & $250 \pm 21$ & $267 \pm 14$ \\
\hline $\begin{array}{l}\text { AVT }^{\mathrm{b}} \text { afluente } \\
\left(\mathrm{mg} \mathrm{HAc} . \mathrm{L}^{-1}\right)\end{array}$ & $109 \pm 22$ & $122 \pm 72$ & $86 \pm 16$ & $150 \pm 50$ & $30 \pm 9$ & $61 \pm 11$ & $49 \pm 7$ & $55 \pm 9$ & $55 \pm 7$ \\
\hline $\begin{array}{l}\text { AVT }^{b} \text { afluente } \\
\left(\mathrm{mg} \mathrm{HAc}^{-1} \mathrm{~L}^{-1}\right)\end{array}$ & $43 \pm 12$ & $48 \pm 32$ & $42 \pm 18$ & $75 \pm 24$ & $23 \pm 6$ & $40 \pm 14$ & $37 \pm 8$ & $44 \pm 9$ & $46 \pm 8$ \\
\hline $\begin{array}{l}\mathrm{DQO}_{\mathrm{t}} \text { afluente }(\mathrm{mg} \\
\left.\mathrm{O}_{2} \cdot \mathrm{L}^{-1}\right)\end{array}$ & $610 \pm 122$ & $644 \pm 225$ & $571 \pm 81$ & $611 \pm 192$ & $229 \pm 96$ & $409 \pm 103$ & $457 \pm 123$ & $471 \pm 109$ & $549 \pm 93$ \\
\hline $\begin{array}{l}\mathrm{DQO}_{\mathrm{t}} \text { efluente (mg } \\
\left.\mathrm{O}_{2} \cdot \mathrm{L}^{-1}\right)\end{array}$ & $236 \pm 83$ & $172 \pm 62$ & $228 \pm 57$ & $222 \pm 66$ & $148 \pm 50$ & $216 \pm 65$ & $181 \pm 42$ & $205 \pm 46$ & $187 \pm 29$ \\
\hline
\end{tabular}

${ }^{\mathrm{a}} \mathrm{AB}$ : Alcalinidade a bicarbonato

${ }^{\mathrm{b}} \mathrm{AVT}$ : Ácidos voláteis totais 
Tabela 5.4 - Continuação.

\begin{tabular}{|c|c|c|c|c|c|c|c|c|c|}
\hline \multirow[b]{2}{*}{ Parâmetros } & \multicolumn{2}{|l|}{ UASB } & \multicolumn{6}{|c|}{ HAnR } & \multirow[b]{2}{*}{ Etapa 9} \\
\hline & Etapa 1 & Etapa 2 & Etapa 3 & Etapa 4 & Etapa 5 & Etapa 6 & Etapa 7 & Etapa 8 & \\
\hline TDH (h) & 8,8 & 7,4 & 6,1 & 5,2 & 4,4 & 3,9 & 5,2 & 3,9 & 7,5 \\
\hline $\begin{array}{l}\mathrm{DQO}_{\mathrm{f}} \text { afluente }(\mathrm{mg} \\
\left.\mathrm{O}_{2} \cdot \mathrm{L}^{-1}\right)\end{array}$ & $255 \pm 35$ & $228 \pm 44$ & $231 \pm 53$ & $223 \pm 51$ & $119 \pm 46$ & $145 \pm 52$ & $168 \pm 48$ & $169 \pm 50$ & $189 \pm 45$ \\
\hline $\begin{array}{l}\mathrm{DQO}_{\mathrm{f}} \text { efluente }(\mathrm{mg} \\
\left.\mathrm{O}_{2} . \mathrm{L}^{-1}\right)\end{array}$ & $112 \pm 26$ & $104 \pm 24$ & $118 \pm 44$ & $123 \pm 39$ & $90 \pm 39$ & $91 \pm 34$ & $115 \pm 41$ & $104 \pm 25$ & $103 \pm 20$ \\
\hline $\begin{array}{l}\mathrm{DBO}_{5,20} \text { afluente } \\
\left(\mathrm{mg} \mathrm{O}_{2} \cdot \mathrm{L}^{-1}\right)\end{array}$ & $215 \pm 54$ & $253 \pm 13$ & $211 \pm 48$ & $251 \pm 73$ & $82 \pm 12$ & $154 \pm 3$ & $168 \pm 37$ & $139 \pm 71$ & $217 \pm 38$ \\
\hline $\begin{array}{l}\mathrm{DBO}_{5,20} \text { efluente } \\
\left(\mathrm{mg} \mathrm{O}_{2} \cdot \mathrm{L}^{-1}\right)\end{array}$ & $78 \pm 22$ & $86 \pm 12$ & $93 \pm 40$ & $105 \pm 30$ & $39 \pm 11$ & $97 \pm 1$ & $73 \pm 12$ & $67 \pm 7$ & $70 \pm 11$ \\
\hline 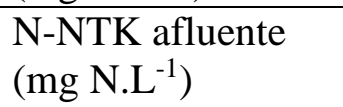 & $72 \pm 12$ & $65 \pm 11$ & $61 \pm 9$ & $61 \pm 11$ & $36 \pm 9$ & $50 \pm 12$ & $51 \pm 8$ & $45 \pm 6$ & $48 \pm 4$ \\
\hline $\begin{array}{l}\text { N-NTK efluente } \\
\left(\mathrm{mg} \mathrm{N}^{-1} \mathrm{~L}^{-1}\right)\end{array}$ & $65 \pm 9$ & $55 \pm 7$ & $56 \pm 9$ & $55 \pm 10$ & $31 \pm 9$ & $47 \pm 11$ & $47 \pm 8$ & $45 \pm 7$ & $52 \pm 3$ \\
\hline $\begin{array}{l}\mathrm{N}-\mathrm{NH}_{4}{ }^{+} \text {afluente } \\
\left(\mathrm{mg} \mathrm{N} \cdot \mathrm{L}^{-1}\right)\end{array}$ & $44 \pm 5$ & $41 \pm 6$ & $40 \pm 7$ & $39 \pm 7$ & $20 \pm 7$ & $34 \pm 9$ & $38 \pm 8$ & $39 \pm 8$ & $44 \pm 5$ \\
\hline $\begin{array}{l}\mathrm{N}-\mathrm{NH}_{4}{ }^{+} \text {efluente } \\
\left(\mathrm{mg} \mathrm{N} \cdot \mathrm{L}^{-1}\right)\end{array}$ & $49 \pm 5$ & $47 \pm 6$ & $45 \pm 8$ & $45 \pm 7$ & $24 \pm 7$ & $38 \pm 9$ & $42 \pm 8$ & $43 \pm 8$ & $50 \pm 4$ \\
\hline $\begin{array}{l}\text { N-org afluente } \\
\left(\mathrm{mg} \mathrm{N} . \mathrm{L}^{-1}\right)\end{array}$ & $29 \pm 9$ & $24 \pm 9$ & $19 \pm 8$ & $22 \pm 6$ & $15 \pm 5$ & $16 \pm 6$ & $13 \pm 5$ & $5 \pm 5$ & - \\
\hline $\begin{array}{l}\text { N-org efluente } \\
\left(\mathrm{mg} \mathrm{N} . \mathrm{L}^{-1}\right)\end{array}$ & $16 \pm 9$ & $9 \pm 4$ & $10 \pm 6$ & $9 \pm 5$ & $7 \pm 3$ & $8 \pm 5$ & $5 \pm 3$ & $4 \pm 2$ & $4 \pm 3$ \\
\hline
\end{tabular}


Tabela 5.4 - Continuação.

\begin{tabular}{|c|c|c|c|c|c|c|c|c|c|}
\hline & UASB & & & & & & & & \\
\hline Parâmetros & Etapa 1 & Etapa 2 & Etapa 3 & Etapa 4 & Etapa 5 & Etapa 6 & Etapa 7 & Etapa 8 & Etapa 9 \\
\hline TDH (h) & 8,8 & 7,4 & 6,1 & 5,2 & 4,4 & 3,9 & 5,2 & 3,9 & 7,5 \\
\hline $\begin{array}{l}\text { SST afluente } \\
\left(\mathrm{mg} \mathrm{SST.L}{ }^{-1}\right)\end{array}$ & $220 \pm 78$ & $262 \pm 101$ & $242 \pm 52$ & $267 \pm 87$ & $157 \pm 70$ & $197 \pm 63$ & $204 \pm 59$ & $203 \pm 75$ & $221 \pm 67$ \\
\hline $\begin{array}{l}\text { SST efluente } \\
\left(\mathrm{mg} \mathrm{SST.L}^{-1}\right)\end{array}$ & $95 \pm 63$ & $54 \pm 35$ & $94 \pm 37$ & $73 \pm 41$ & $51 \pm 27$ & $98 \pm 36$ & $50 \pm 18$ & $73 \pm 30$ & $55 \pm 17$ \\
\hline 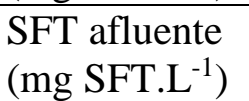 & $49 \pm 28$ & $66 \pm 35$ & $69 \pm 31$ & $77 \pm 35$ & $66 \pm 44$ & $65 \pm 39$ & $54 \pm 28$ & $57 \pm 44$ & $60 \pm 38$ \\
\hline $\begin{array}{l}\text { SFT efluente } \\
\left(\mathrm{mg} \mathrm{SFT.L}{ }^{-1}\right)\end{array}$ & $31 \pm 25$ & $18 \pm 13$ & $20 \pm 3$ & $25 \pm 16$ & $16 \pm 9$ & $34 \pm 15$ & $14 \pm 11$ & $22 \pm 22$ & $15 \pm 11$ \\
\hline $\begin{array}{l}\text { SVT afluente } \\
\left(\mathrm{mg} \mathrm{SVT.L} \mathrm{L}^{-1}\right)\end{array}$ & $172 \pm 57$ & $196 \pm 74$ & $171 \pm 23$ & $190 \pm 65$ & $92 \pm 36$ & $132 \pm 42$ & $150 \pm 43$ & $146 \pm 48$ & $161 \pm 49$ \\
\hline $\begin{array}{l}\text { SVT efluente } \\
\left(\mathrm{mg} \mathrm{SVT.L}{ }^{-1}\right)\end{array}$ & $65 \pm 40$ & $35 \pm 24$ & $50 \pm 7$ & $49 \pm 31$ & $36 \pm 22$ & $64 \pm 23$ & $35 \pm 15$ & $52 \pm 22$ & $39 \pm 11$ \\
\hline
\end{tabular}

${ }^{a} \mathrm{AB}$ : Alcalinidade a bicarbonato

b AVT: Ácidos voláteis totais 


\subsection{QUANTIFICAÇÃO DA BIOMASSA ADERIDA NOS SUPORTES}

Após o término da fase experimental (Etapa 9), o HAnR foi desmontado e amostras representativas do material suporte, Biobob®, foram retiradas do leito fixo do reator para a quantificação da biomassa aderida. Na Figura 5.22 são apresentadas fotos das amostras de Biobob® retiradas do leito fixo do HAnR.

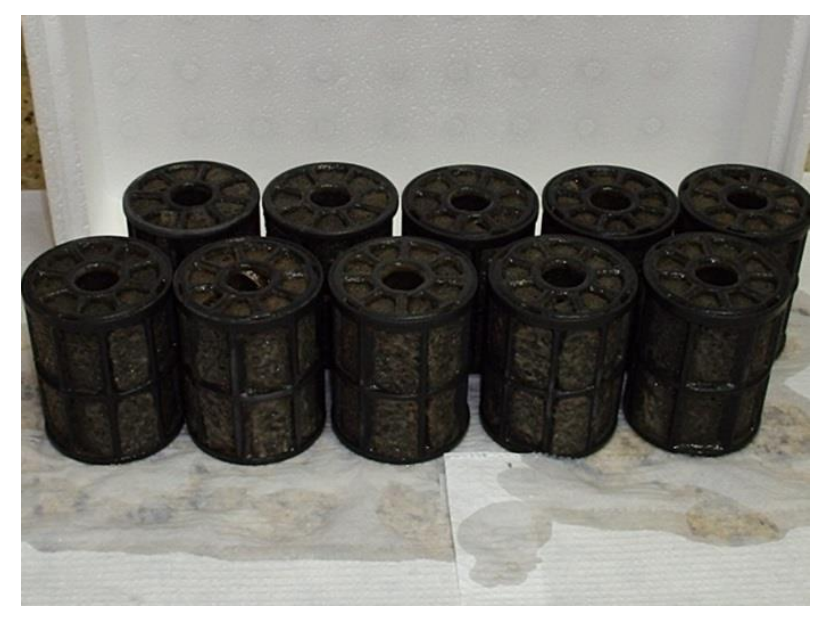

Figura 5.22 - Fotos das amostras de Biobob® coletadas do leito fixo do HAnR.

Embora as amostras do material suporte tenham sido retiradas quando o HAnR estava submetido à baixa COV aplicada, 1,6 $\pm 0,3 \mathrm{~kg} \mathrm{DQO} \cdot \mathrm{m}^{-3} \cdot \mathrm{d}^{-1}$ (TDH de 7,5 h), o Biobob® apresentou alta retenção de biomassa por volume de suporte, com valores médios de 5,7 kg SVT.m ${ }^{-3}$, conforme apresentado na Tabela 5.5.

Tabela 5.5 - Quantificação da biomassa aderida no material suporte.

\begin{tabular}{lc}
\cline { 2 - 2 } & Valores \\
\hline Volume líquido do reator $\left(\mathrm{m}^{3}\right)$ & 11,0 \\
Volume de Biobob® $\left(\mathrm{m}^{3}\right)$ & 5,0 \\
Quantidade de Biobob® (unidade) & 27.500 \\
Biomassa aderida no Biobob® $\left(\mathrm{mg} \mathrm{SVT.und}{ }^{-1}\right)$ & $1028 \pm 114$ \\
Concentração equivalente de biomassa $\left(\mathrm{kg} \mathrm{SVT}^{-3} \mathrm{~m}^{-3}\right)$ & $5,65 \pm 250$ \\
\hline
\end{tabular}

A alta concentração de biomassa acompanha os resultados obtidos por van Rompu et al. (1990) e Tilche et al. (1991), os quais obtiveram concentrações de biomassa aderida

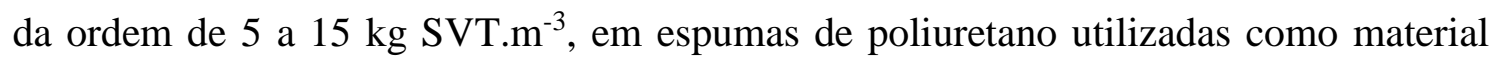
suporte em filtros anaeróbios. 


\subsection{RENDIMENTO E PRODUÇÃO DE SÓlidOS ( $\mathbf{Y}_{\mathrm{obs}}$; P $\mathbf{P}_{\text {Lodo }}$ )}

O rendimento ( $\left.\mathrm{Y}_{\mathrm{obs}}\right)$ e a produção de sólidos ( $\left.\mathrm{P}_{\text {Lodo }}\right)$ para o HAnR foram estimadas para o período experimental compreendido entre o $69^{\circ}$ ao $468^{\circ}$ dia, por meio da quantificação dos sólidos descartados pela via convencional (descarte do leito de lodo), bem como pelos sólidos descartados de modo involuntário no efluente tratado.

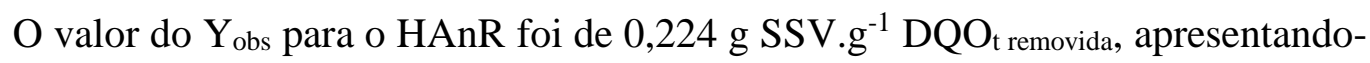
se acima dos valores reportados por Metcalf e Eddy (2003) para reatores anaeróbios (Y

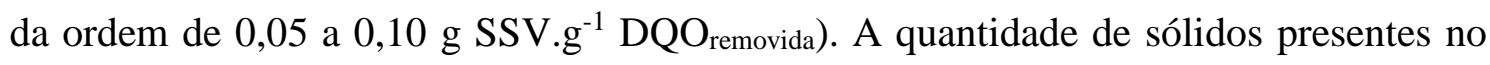
efluente representou $68,7 \%$ do total produzido no reator (expresso como SSV). Deste modo, com o objetivo de minimizar o impacto causado pela parcela dos sólidos no efluente tratado no cálculo do $\mathrm{Y}_{\mathrm{obs}}$, calculou-se o $\mathrm{Y}^{\prime}$ obs, onde a carga orgânica removida foi estimada por meio da DQO total afluente e da DQO filtrada efluente. Assim, o Y' ${ }_{\text {obs }}$

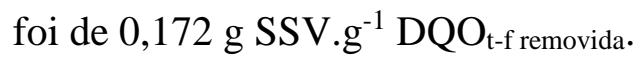

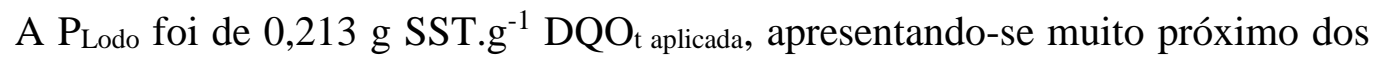
valores reportados por Chernicharo (2007) para reatores anaeróbios $(0,10$ a 0,20 g SST.g${ }^{1}$ DQO $_{\mathrm{t} \text { aplicada). }} \mathrm{O}$ balanço de massa da produção de sólidos no HAnR é apresentada na Tabela 5.6.

Tabela 5.6 - Balanço de massa da produção de sólidos no HAnR durante o período operacional.

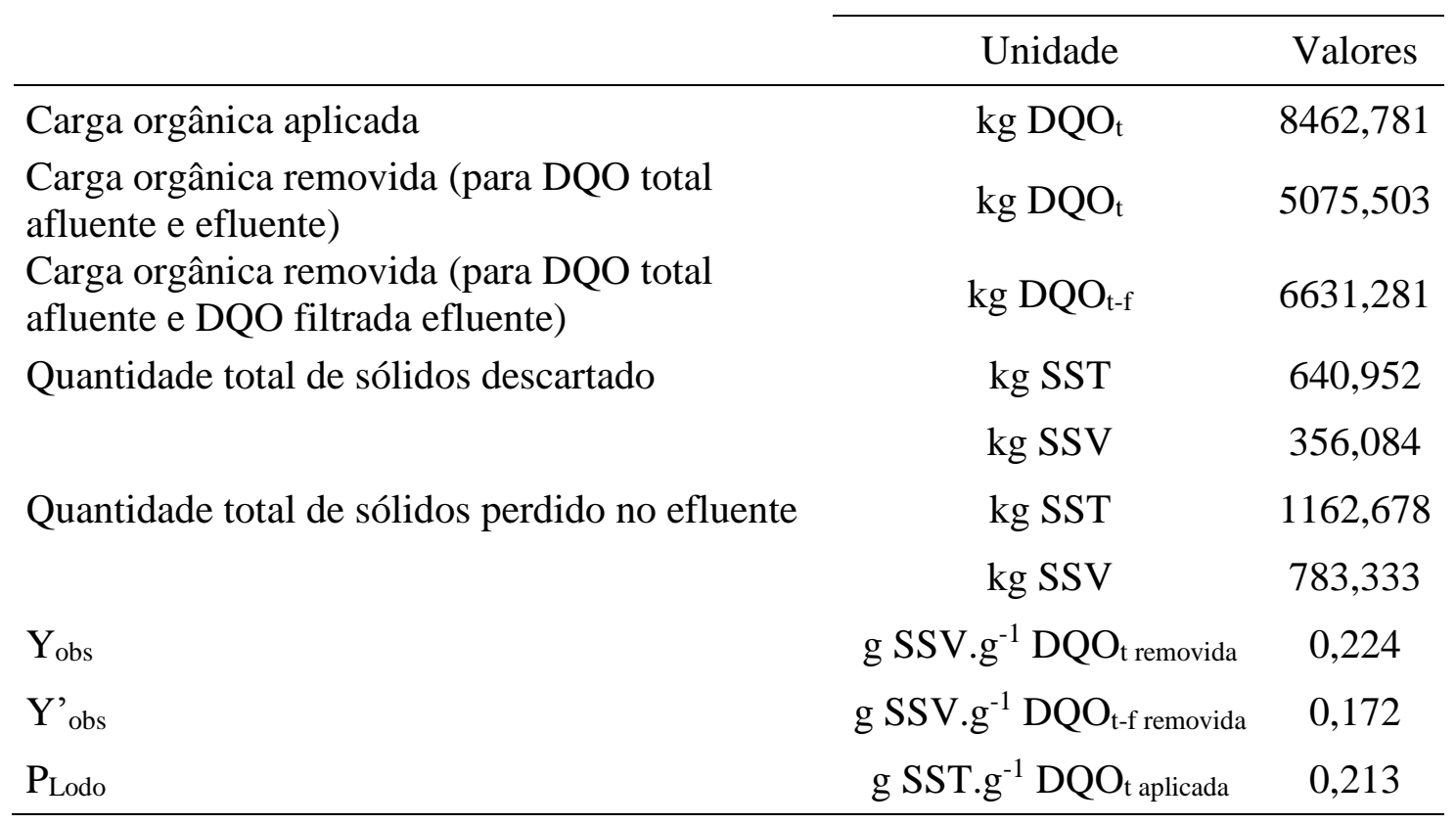





\section{Conclusões}

O principal resultado deste trabalho foi a constatação da viabilidade técnica da aplicação do reator anaeróbio híbrido (leito fixo e manta de lodo) como unidade principal de tratamento de esgotos sanitários quando comparado à utilização de reatores UASB.

Outro resultado também constatado e de igual importância foi a viabilidade técnica da aplicação do material suporte para a imobilização celular, Biobob®, para o aumento de capacidade de tratamento de reatores UASB, sem a necessidade de ampliações físicas do reator.

O reator anaeróbio híbrido $(\mathrm{HAnR})$ se mostra promissor para o tratamento de águas residuárias com baixa concentração de matéria orgânica e alta concentração de sólidos em suspensão, como os esgotos sanitários, tendo algumas vantagens sobre os sistemas convencionais de tratamento anaeróbio por reator UASB, tais como, menor área de implantação, melhor qualidade do efluente tratado, pequena geração de lodo e simplicidade operacional.

A melhor condição operacional do HAnR quando comparado, em termos de eficiências de remoção e qualidade do efluente tratado, com o reator UASB foi conseguida aplicando-se tempo de detenção hidráulica (TDH) de 5,2 h, com base no volume útil do reator, e velocidade ascensional aparente $\left(\mathrm{v}_{\mathrm{s}}\right)$ de $0,94 \mathrm{~m} \cdot \mathrm{h}^{-1}$, apresentando eficiências na remoção de DQO e SST de $61 \pm 16 \%$ e $72 \pm 16 \%$, respectivamente, com

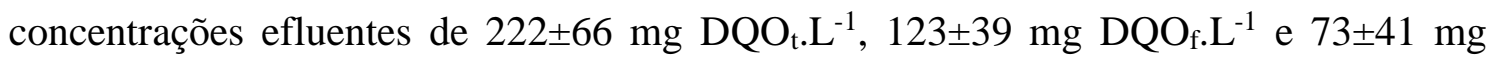
SST.L $L^{-1}$, porém com uma CHV de $4,1 \mathrm{~m}^{3} \cdot \mathrm{m}^{-3} \cdot \mathrm{d}^{-1}, 52 \%$ maior do que a aplicada no reator $\operatorname{UASB}\left(2,7 \mathrm{~m}^{3} \cdot \mathrm{m}^{-3} \cdot \mathrm{d}^{-1}\right)$.

Em relação aos resultados específicos do trabalho, foi possível tirar as seguintes conclusões: 
- Para condições de operação similares, o HAnR submetido a carga hidráulica

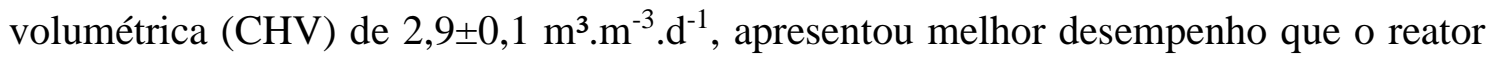

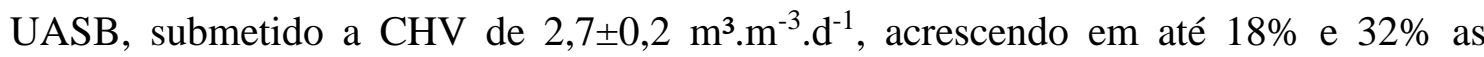
eficiências de remoção de $\mathrm{DQO}_{\mathrm{t}}$ e SST, respectivamente.

- Embora o reator UASB, submetido à $\mathrm{v}_{\mathrm{s}}$ de $0,63 \pm 0,05 \mathrm{~m} \cdot \mathrm{h}^{-1}$ e TDH de $8,8 \pm 1,1 \mathrm{~h}$, tenha apresentado boa qualidade do efluente tratado com concentrações médias de $236 \pm 83 \mathrm{mg}$

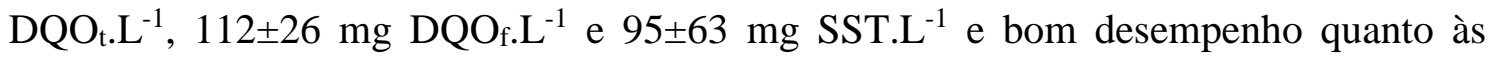
eficiências de remoção de $\mathrm{DQO}_{\mathrm{t}}(61 \pm 12 \%)$ e SST $(60 \pm 23 \%)$, o HAnR apresentou melhor qualidade do efluente tratado mesmo quando submetido a maiores velocidades

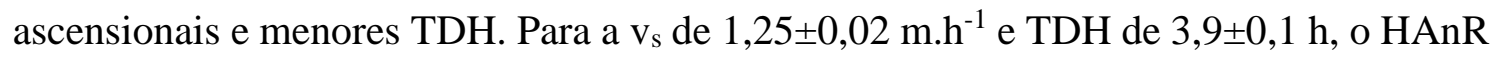
apresentou concentrações médias no efluente tratado de $205 \pm 46 \mathrm{mg} \mathrm{DQO}_{\mathrm{t} . \mathrm{L}^{-1}}, 104 \pm 25$

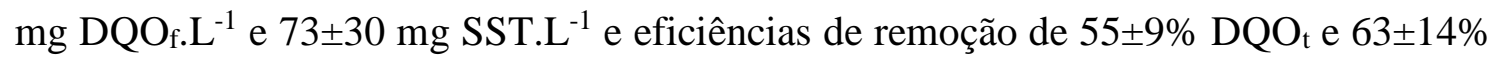
SST.

- O rendimento da produção de sólidos observada ( $\left.\mathrm{Y}_{\mathrm{obs}}\right)$ para o HAnR foi de 0,224 g

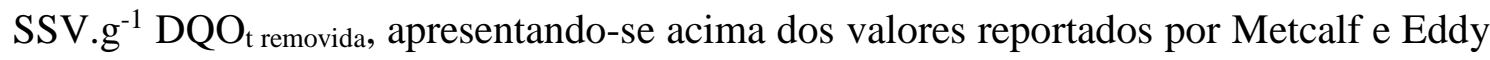
(2003) para reatores anaeróbios (Y da ordem de 0,05 a 0,10 g SSV.g-1 DQO removida). Entretanto, é importante ressaltar que os autores Metcalf e Eddy (2003) utilizam para o cálculo do rendimento da produção de biomassa (Y) a DQO solúvel e biodegradável, enquanto que o presente trabalho, devido as limitações do método utilizado, utilizou a DQO total afluente e efluente para o cálculo da carga orgânica removida. Outro fato importante é que a quantidade de sólidos presentes no efluente representou $68,7 \%$ do total produzido no reator (expresso como SSV). Deste modo, o Y ${ }^{\prime}$ obs de 0,172 g SSV.g g $^{-1}$ DQO $_{\mathrm{t}}$ f removida, onde a carga orgânica removida foi estimada por meio da DQO total afluente e da DQO filtrada efluente, representa de modo mais adequado o rendimento da produção de sólidos observada.

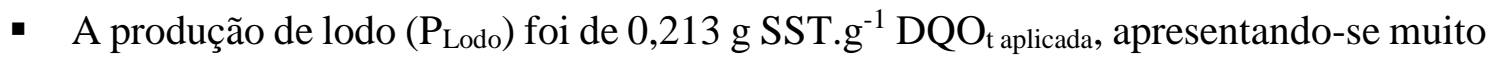
próximo dos valores reportados por Chernicharo (2007) para reatores anaeróbios $(0,10$ a 0,20 g SST.g ${ }^{-1}$ DQO $_{\text {t aplicada }}$ ). 


\section{Sugestões}

A partir dos resultados obtidos neste trabalho, propõem-se as seguem sugestões para o aprimoramento de reatores anaeróbios híbridos:

- Estudar novos suportes para imobilização celular, bem como o arranjo destes suportes no leito reacional (leito empacotado e ordenado);

- Aumentar a escala do reator anaeróbio híbrido e estudar a distribuição hidrodinâmica do sistema;

- Investigar as diferenças entre as substâncias poliméricas extracelulares produzidas pela biomassa presente no leito de lodo e aderida ao material suporte;

- Investigar o desempenho do reator anaeróbio híbrido tratando esgotos sanitários pré-tratado (após tratamento preliminar e primário);

- Investigar o desempenho do reator anaeróbio híbrido tratando outros tipos de água residuária. 



\section{Referências Bibliográficas}

AIYUK, S.; AMOAKO, J.; RASKIN, L.; van HAANDEL, A.; VERSTRAETE, W. (2004). Removal of carbon and nutrients from domestic wastewater using a low investment, integrated treatment concept. Water Research, 38(13): 3031-3042.

AIYUK, S.; FORSTER, I.; LIEVEN, D.K.; van HAANDEL, A.; VERSTRAETE, W. (2006). Anaerobic and complementary treatment of domestic sewage in regions with hot climates - a review. Bioresource Technology, 97(17): 2225-2241.

AIYUK, S.E. \& VERSTRAETE, W. (2004). Sedimentological evolution in an UASB treating SYNTHES, a new representative synthetic sewage, at low loading rates. Bioresource Technology, 93: 269-278.

ALVES, M.M. (1999). A new device to select microcarries for biomass immobilization to an anaerobic consortium. Water Environment Research, 71(2): 209-217.

ANDERSON, G.K.; KASAPGIL, B.; INCE, O. (1994). Comparison of porous and nonporous media in upflow anaerobic filters when treating dairy wastewater. Water Research, 28: 1619-1624.

ARAUJO JUNIOR, M.M. (2006). Reator combinado anaeróbio-aeróbio de leito fixo para remoção de matéria orgânica e nitrogênio de água residuária de indústria produtora de lisina. Tese de Doutorado. Escola de Engenharia de São Carlos, Universidade de São Paulo. 
ARAUJO JUNIOR, M.M.; ZAIAT, M. (2009). An upflow fixed-bed anaerobic-aerobic reactor for removal of organic matter and nitrogen from L-lysine plant wastewater. Can. J. Civil Eng. 36: 1085-1094.

ARAUJO JUNIOR, M.M.; ARAUJO, T.L.S.; ZAIAT, M. Submitted for publication. Sequential anaerobic-aerobic fixed-bed reactors employing an innovative packing material for domestic wastewater treatment. Water Science and Technology.

ATKINSON, B. (1974). Biochemical reactors. Pion, London.

BORJA, R. \& BANKS, J.C. (1995). Response of an anaerobic fluidized bed reactor treating ice-cream wastewater to organic, hydraulic, temperature and $\mathrm{pH}$ shocks. Journal of Biotechnology, 39(3): 251-259.

BRITO, A.G. \& MELO, L.F. (1999). Mass transfer coefficients within anaerobic biofilms: effects of external liquid velocity. Water Research, 33(17): 3673-3678.

BUTLER, D.; FRIEDLER, E.; GATT, K. (1995). Characterizing the quantity and quality of domestic wastewater inflows. Water Science and Technology, 31(7): 13-24.

CALZADA, J.F.; de ARRIOLA, M.C.; CASTANEDA, J.E.; GODOY, J.E.; ROLZ C. (1984). Methane from coffee pulp juice: experiments using polyurethane foam reactors. Biotechnology Letters, 6: 385-388.

CAMPOS, H.M.; von SPERLING, M. (1996). Estimation of domestic wastewater characteristics in a developing country based on socio-economic variables. Water Science and Technology, 34(3/4): 71-77.

CÁNOVAS-DÍAZ, M. \& HOWELL, J.A. (1988). Downflow fixed-film anaerobic reactors stability studies under organic and hydraulic overloading at different working volume. Water Research, 22(5): 529-536. 
CARVALHO, K.Q. (2006). Resposta dinâmica de reator UASB em escala piloto submetido a cargas orgânicas e hidráulicas cíclicas: modelos matemáticos e resultados experimentais. Tese de Doutorado. Escola de Engenharia de São Carlos, Universidade de São Paulo.

CASTILlO, A.; CECCHI, F.; MATA-ALVAREZ, J. (1997). A combined anaerobicaerobic system to treat domestic sewage in coastal areas. Water Research, 31(12): 3057-3063.

CHERNICHARO, C.A.L. (2007). Biological wastewater treatment. Anaerobic reactors. IWA Publishing, 4: 175.

CHERNICHARO, C.A.L.; van HAANDEL, A.C.; CYBIS, L.F.; FORESTI, E. (2001). Pós-tratamento de efluentes de reatores anaeróbios. (CHERNICHARO, C.A.L., coordenador). Finep/PROSAB, Rio de Janeiro, RJ, Brasil, cap. 1: 544.

CHUA, H.; HU, W.F.; YU, P.H.F.; CHEUNG, M.W.L. (1997). Response of an anaerobic fixed-film reactor to hydraulic shock loadings. Bioresource Technology, 61: 79-83.

COHEN, A.; BREURE, A.M.; van ANDEL, J.G.; van DEURSEN, A. (1982). Influence of phase separation on the anaerobic digestion of glucose-II: stability, and kinetic response to shock loadings. Water Research, 16: 449-455.

CORDOBA, P.R.; FRANCESE, A.P.; PROIMI F.S. (1995). Improved performance of a hybrid design over an anaerobic filter for the treatment of dairy wastewater at laboratory scale. Journal of Fermentation and Bioengineering, 79(3): 270-272.

CRITES, R. \& TCHOBANOGLOUS, G. (1998). Small and decentralized wastewater management systems, McGraw Hill, Boston, USA.

DAMIANOVIC, M.H.R.Z. \& FORESTI, E. (2009). Dynamics of sulfidogenesis associated to methanogenesis in horizontal-flow anaerobic immobilized biomass reactor. Process Biochemistry, 44: 1050-1054. 
de ALMEIDA, P.G.S.; CHERNICHARO, C.A.L.; SOUZA, C. L. (2009). Development of compact UASB/trickling filter systems for treating domestic wastewater in small communities in Brazil. Water Science and Technology, 59(7): 1431-1439.

de MAN, A.W.A.; GRIN, P.C.; ROERSMA, R.; GROLLE, K.C.F.; LETTINGA, G. (1986). Anaerobic treatment of sewage at low temperatures. Proceedings of the Anaerobic Treatment a Grown-up Technology, Amsterdam, The Netherlands: 45166.

de MAN, A.W.A.; van der LAST, A.R.M.; LETTINGA, G. (1988). The Use of EGSB and UASB anaerobic systems for low strength soluble and complex wastewaters at temperatures ranging from 8 to $30^{\circ} \mathrm{C}$. In: Hall, E.R. \& Hobson, P.N. (Eds). Proceedings of the fifth international symposium on anaerobic digestion. Bologna, Italy: 735-738.

DERYCKE, D. \& VERSTRAETE, W. (1986). Anaerobic treatment of domestic wastewater in a lab and pilot scale polyurethane carrier reactor. Proceedings of the Anaerobic Treatment a Grown-up Technology, Amsterdam, The Netherlands: 437450.

DILALLO, R. \& ALBERTSON, O.E. (1961). Volatile acids by direct titriation. Journal Water Pollution Control Federation, 31(10): 2495-2499.

DUGAN, P.R. (1987). The function of microbial polysaccharides in bioflocculation and biosorption of mineral ions. In: Attia, Y.A. (Ed.). Proceedings of the Flocculation in Biotechnology and Separation Systems. Elsevier Science Publishers B.V., The Netherlands: $337-350$.

ELMITWALLI, T.A.; OAHN, K.L.T.; ZEEMAN, G.; LETTINGA, G. (2002). Treatment of domestic sewage in a two-step anaerobic filter/ anaerobic hybrid system at low temperature. Water Research, 36: 2225-2232. 
ELMITWALLI, T.A.; SOELLNER, J.; de KEIZER, A.; ZEEMAN, G.; BRUNING, H.; LETTINGA, G. (2001). Biodegradability and change of physical characteristics of particles during anaerobic digestion of domestic sewage. Water Research, 35(5): 1311-7.

ELMITWALLI, T.A.; van DUN, M.; ZEEMAN, G.; BRUNING, H.; LETTINGA, G. (2000). The role of filter media in removing suspended and colloidal particles in anaerobic reactor treating domestic sewage. Bioresource and Technology, 72(3): 235-40.

ELMITWALLI, T.A.; ZANDVOORT, M.; ZEEMAN. G.; BRUNING, H.; LETTINGA, G. (1999). Low temperature treatment of domestic sewage in upflow anaerobic sludge blanket and anaerobic hybrid reactors. Water Science and Technology, 39(5): 177-85.

ENG, S.C.; FERNANDES, X.A.; PASKINS, A.R. (1986). Biochemical effects of administering shock loads of sucrose to a laboratory-scale anaerobic (UASB) effluent treatment plant. Water Research, 20(6): 789-794.

ERIKSSON, L. \& AXBERG, C. (1981). Direct influence of wastewater pollutants on flocculation and sedimentation behaviour in biological wastewater treatment: 1 Model system E. coli B. Water Research, 15: 421-431.

FLEMMING, H.-C. (1995). Sorption sites in biofilms. Water Science and Technology, 32(8): 27-33.

FLORENCIO, L.; KATO, M.T.; DE MORAIS, J.C. (2001). Domestic sewage treatment in full-scale UASBB plant at Mangueira, Recife, Pernambuco. Water Science and Technology, 44(4): 71-77.

FONGASTITKUL, P.; MAVINIC, D.S.; LO, K.V. (1994). A two-phased anaerobic digestion process: concept, process failure and maximum system loading rate. Water Environment Research, 66(3): 243-254. 
FORESTI, E. (2001). Anaerobic treatment of domestic sewage: established technologies and perspectives. In: Proceedings of the $9^{\text {th }}$ World Congress on Anaerobic Digestion - Anaerobic Conversion for Sustainability, Antwerp, Belgium: 37-42.

FORESTI, E.; FLORENCIO, L.; van HAANDEL, A.; ZAIAT, M.; CAVALCANTI, P. F.F. (1999). Fundamentos do tratamento anaeróbio. In: Tratamento de esgotos sanitários por processo anaeróbio e disposição controlada no solo. ABES, Rio de Janeiro: 29-52.

FORESTI, E.; ZAIAT, M.; VALLERO, M. (2006). Anaerobic processes as the core technology for sustainable domestic wastewater treatment: Consolidated applications, new trends, perspectives, and challenges. Reviews in Environmental Science and Bio/Technology, 5: 3-19.

FORSTER, C.F. (1981). Preliminary studies on the relationship between sewage sludge viscosities and the nature of the surfaces of the component particles. Biotechnology Letters, 3(12): 707-712.

FORSTER, C.F. \& DALLAS-NEWTON, J. (1980). Activated sludge settlement: some suppositions and suggestions. Journal of the Water Pollution Control Federation, 79: $338-351$.

FROLUND, B.; PALMGREN, R.; KEIDING, K.; NIELSEN, P.H. (1996). Extraction of extracellular polymers from activated sludge using a cation exchange resin. Water Research, 30(8): 1749-1758.

FYNN, G.H. \& WHITMORE, T.N. (1984). Retention of methanogens in colonised reticulated polyuethane foam biomass support particle. Biotechnology Letters, 6: 8186.

GIJZEN, H.J.; SCHOENMAKERS, T.J.M.; CAERTELING, C.G.M.; VOGELS, G.D. (1988). Anaerobic degradation of papermill sludge in a two-phase digester containing rumen microorganisms and colonized polyurethane foam. Biotechnology Letters, 10(1): 61-66. 
GHOSH, S. \& LALL, U. (1981). Kinetics of anaerobic digestion of solid substrates. In: Anaerobic digestion. Proceedings of the $5^{\text {th }}$ International Symposium on Anaerobic Digestion: 365-373.

GONÇALVES, R.F.; CHA LIER, A.C.; SAMMUT, F. (1994). Primary fermentation of soluble and particulate organic matter for wastewater treatment. Water Science and Technology, 30(6): 53-62.

GONÇALVES, R.F.; PASSAMANI, F.R.F.; SALIM, F.P.; SILVA, A.L.B.; MARTINELI, G.; BAUER D.G (2000). Associação de um reator UASB e biofiltros aerados submersos para tratamento de esgoto sanitário. Pós-tratamento de efluentes de reatores anaeróbios - Coletânea de Artigos Técnicos, 1:119-134, FINEP/PROSAB.

GUIOT, S.R. \& van den BERG, L. (1984). Performance and biomass retention of the anaerobic reactor combining a sludge blanket and a filter. Biotechnology Letters, 6(3): 161-164.

GUO, W., NGO, H.H., DHARMAWAN, F., PALMER, C.G. (2010). Roles of polyurethane foam in aerobic moving and fixed bed bioreactors. Bioresource and Technology, 101(5): 1435-1439.

HALL, E.R. (1984). Improving hydraulic efficiency in high rate anaerobic systems. In: Pollution Control Association of Ontario and the Ontario Ministry of the Environment. Ontario Seminar "Bridging the Gap Between Research and Full-Scale Operation in Wastewater Treatment", Burlington, Canada: 55.

HANAI, F.Y. (1997). Caracterização qualitativa e quantitativa de esgotos sanitários. Dissertação de Mestrado. Escola de Engenharia de São Carlos, Universidade de São Paulo.

HANG, S.S. \& BYEONG, C.P. (1990). Improved performance of upflow anaerobic sludge blanket (UASB) reactors by operating alternatives. Biotechnology Letters, 12 : 469-474. 
HAPPER, S.R. \& POHLAND, F.G. (1986). Recent developments in hydrogen management during anaerobic biological wastewater treatment. Biotechnology \& Bioengineering, 28: 585-602.

HARADA, H.; ENDO, G.; TOHYA, Y.; MOMONOI, K. (1988). High rate performance and its related characteristics of granulated sludges in UASB reactors treating various wastewaters. In: Proceedings of the $5^{\text {th }}$ International Symposium on Anaerobic Digestion, Bologna, Italy: 1011-1019.

HENZE, M.; HARREMO€ES, P.; JANSEN, J.; ARVIN, E. (1995). Wastewater treatment: biological and chemical processes. Springer-Verlag, Berlin, Heidelberg.

HULSHOFF POL, L.W., DE CASTRO LOPES, S.I., LETTINGA, G., LENS P.N.L. (2004). Anaerobic sludge granulation. Reviews in Water Research, 38: 1376-1389.

HUYSMAN, P.; van MEENEN, P.; van ASSCHE, P.; VERSTRAETE, W. (1983). Factors affecting colonization of nonporous packing materials in model upflow methane reactors. Biotechnology Letters, 5: 643-648.

IBGE - INSTITUTO BRASILEIRO DE GEOGRAFIA E ESTATÍSTICA (2010). Pesquisa nacional de saneamento básico 2008. Rio de Janeiro, Brasil.

IWAI, S. \& KITAO, T. (1994). Wastewater treatment with microbial films. Technomic Inc., USA.

JAWED, M. \& TARE, V. (2000). Post-mortem examination and analysis of anaerobic filters. Bioresource and Technology, 72(1): 75-84.

JERIS, J.S. \& McCARTY, P.L.J. (1965). Biochemistry of methane fermentation using C 14 tracers. Journal Water Pollution Control Federation, 37: 178.

JIA, X.S.; FURUMAI, H.; FANG, H.H.P. (1996). Yields of biomass and extracellular polymers in four anaerobic sludges. Environmental Technology, 17: 283-291. 
KALOGO, Y. \& VERSTRAETE, W. (2000). Technical feasibility of the treatment of domestic wastewater by a CEPS-UASB system. Environmental Technology, 21(1): $55-65$.

KAlOGO, Y. \& VERSTRAETE, W. (2001). Potentials of anaerobic treatment of domestic sewage under temperate climate conditions. In: Lens, P.; Zeeman, G.; Lettinga, G. (Eds). Descentralised sanitation and reuse: Concepts, systems and implementation. IWA Publishing, London, UK: 181-204.

KASSAB, G. (2010). Sequential anaerobic-aerobic treatment for domestic wastewater a review. Bioresource and Technology, 101: 3299-3310.

KATO, M.T. (1994). The Anaerobic Treatment of Low Strength Soluble Wastewaters. Ph.D. Thesis. Wageningen University, The Netherlands.

KATO, M. T., NETO, C. O. A., CHERNICHARO C.A.L; FORESTI, E., CYBIS, L. F. (1999). Configurações de reatores anaeróbios. In: Tratamento de esgotos sanitários por processo anaeróbio e disposição controlada no solo (CAMPOS, J.R., coordenador). Finep/CNPq/Caixa/PROSAB, ed. Rima, São Carlos, SP, Brasil, cap. 3: $155-198$.

KENNEDY, K.J. \& DROSTE, R.L. (1991). Anaerobic wastewater treatment in downflow stationary fixed film reactors. Water Science and Technology, 24(8): 157177.

KENNEDY, K.J. \& GUIOT, S.R. (1986). Anaerobic upflow development and application. Water Science and Technology, 18(12): 71-86.

KOBAYASHI, H.A.; STENSTRON, M.K.; MAH, R.A. (1983). Treatment of low strength wastewater using the anaerobic filter. Water Research, 17(8): 903-909.

LEITÃO, R.C. (2004). Robustness of UASB reactors treating sewage under tropical conditions. Ph.D. Thesis. Wageningen University. 
LEITÃO, R.C.; VAN HAANDEL, A.C.; ZEEMAN, G.; LETTINGA, G. (2005). The effects of operational and environmental variations on anaerobic wastewater treatment systems: A review. Bioresource Technology, 97: 1105-1118.

LETTINGA, G.; van VELSEN, A.F.M.; HOBMA, S.W.; de ZEEUW, W.; KLAPWIJK, A. (1980). Use of the upflow sludge blanket (UASB) reactor concept for biological wastewater treatment, especially for anaerobic treatment. Biotechnology \& Bioengineering, 22: 699-734.

LETTINGA, G.; ROERSMA, R.; GRIN, P. (1983). Anaerobic treatment of raw domestic sewage at ambient temperature using a granular bed UASB reactor. Biotechnology \& Bioengineering, 25: 1701-1723.

LETTINGA, G.; de ZEEUW, W.; WIEGANT, W.; HOLSHOFF POL, L. (1987). Highrate anaerobic granular sludge UASB-reactors for wastewater treatment. Bioenviron. Syst., 1: 132-159.

LETTINGA, G. \& HULSHOFF POL, L.W. (1991). UASB Process design for various types of wastewaters. Water Science and Technology, 24: 87-107.

LETTINGA, G.; HULSHOFF POL, L.W.; ZEEMAN G. (1996). Biological wastewater treatment. Part I: Anaerobic wastewater treatment. Lecture notes. Wageningen Agricultural University, January 1996.

LETTINGA, G.; HULSHOFF POL, L.W.; ZEEMAN, G.; FIELD, J.; van LIER, J.B.; van BUNSEN, J.C.L.; JANSSEN, A.J.H.; LENS, P. (1997). Anaerobic treatment in sustainable environmental production concepts. In: Proceedings of the $8^{\text {th }}$ Conference on Anaerobic Digestion, 1: 32-39.

LETTINGA, G. (2001). Potential of anaerobic pre-treatment (AnWT) of domestic sewage under tropical conditions. In: Lens, P.; Zeeman, G.; Lettinga, G. (Eds). Descentralised sanitation and reuse: Concepts, systems and implementation. IWA Publishing, London, UK: 205-216. 
LEVINE, A.D.; TCHOBANAGLOUS, G.; ASANO, T. (1985). Characterization of the size distribution of contaminants in wastewater: treatment and reuse implications. Journal Water Pollution Control Federation, 57(7): 805-816.

LIM, J.W.; SENG, C.E.; LIM, P.E.; NG, S.L.; SUJARI, A.N.A. (2011). Nitrogen removal in moving bed sequencing batch reactor using polyurethane foam cubes of various sizes as carrier materials. Bioresource and Technology, 102: 9876-9883.

MAGERA, Y.; NAMBU, S.; UTOSAWA, K. (1976). Biochemical and physical properties of an activated sludge on settling characteristics. Water Research, 10: 7177.

MAHMOUD, N.; ZEEMAN, G.; GIJZEN, H.; LETTINGA, G. (2003). Solids removal in upflow anaerobic reactors: A review. Bioresource and Technology, 90: 1-9.

MARSHALL, K.C. (1967). Electrophoretic properties of fast- and slow-growing species of rhizobium. Australian Journal of Biological Sciences, 20: 429.

McCARTY, P.L. (1982). One hundred years of anaerobic treatment. In: Hughes, E.; Stafford, D.A.; Wheatley, B.I.; Baader, W.; Lettinga, G.; Nyns, E.J.; Verstraete, W.; Wentworth, R.L. (1981). Anaerobic digestion. Elsevier Biomedical Press BV, Amsterdam: 3-22.

METCALF \& EDDY, Inc. (2003). Wastewater Engineering: Treatment and Reuse. McGraw Hill, $4^{\text {th }}$ edition: 1819.

MIYAHARA, T. \& NOIKE, T. (1994). Behaviour of suspended solids and anaerobic bacteria in an anaerobic fixed bed reactor. Water Science \& Technology, 30(12): 7586.

MORGAN, J.W.; FORSTER, C.F.; EVISON, L. (1990). A comparative study of the nature of biopolymers extracted from anaerobic and activated sludges. Water Research, 24(6): 743-750. 
MOSEY, F.E. (1983). Mathematical modelling of the anaerobic digestion process: regulatory mechanisms for the formation of short-chain volatile acids from glucose. Water Science and Technology, 15: 209-232.

MUYZER, G. \& STAMS, A.J.M. (2008). The ecology and biotechnology of sulphatereducing bacteria. Nature Reviews Microbiology, 6: 441-454.

ODEGAARD, H. (1999). The influence of wastewater characteristics on choice of wastewater treatment method. In: Proceedings of the Nordic Conference on: Nitrogen Removal and Biological Phosphate Removal, Oslo, Norway.

OLIVA, L.C.H.V. (1997). Tratamento de esgotos sanitários com reator anaeróbio de manta de lodo (UASB) protótipo: desempenho e respostas dinâmicas às sobrecargas hidráulicas. Tese de Doutorado. Escola de Engenharia de São Carlos, Universidade de São Paulo.

ORHON, D. et al. (1997). Characterization and COD fractionation of domestic wastewaters. Environmental Pollution, 95(2): 191-204.

PASSIG, F.H.; VILLELA, L.H.; FERREIRA, O.P. (2000). Piracicamirim sewage treatment plant-conception utilizing anaerobic process followed by aerobic process: evaluation of operational conditions and compatibility of the processes. In: Foresti et al. (Eds). Proceedings of the IV Latin-American Workshop and Seminar on Anaerobic Digestion, 1: 53-59.

POXON, T.L. \& DARBY, J.L. (1997). Extracellular polyanions in digested sludge: measurement and relationship to sludge dewaterability. Water Research, 31(4): 749758.

REYNOLDS, P.J. \& COLLERAN, E. (1986). Comparison of start-up and operation of anaerobic fixed-bed and hybrid sludge-bed/fixed-bed reactors treating whey wastewater. Proc. EWPCA Conf. on Anaerobic Treatment, Amsterdam: 515. 
RATUSZNEI S.M.; RODRIGUES, J.A.D.; CAMARGO, E.F.M.; ZAIAT, M.; BORZANI, W. (2000). Feasibility of a stirred anaerobic sequencing batch reactor containing immobilized biomass for wastewater treatment. Bioresource Technology, 75(2): 127-132.

RIPLEY, L.E.; BOYLE, W.C.; CONVERSE, J.C. (1986). Improved alkalinimetric monitoring for anaerobic digestion of high-strength wastes. Journal Water Polution Control Federation, 58: 406-411.

SCHELLINKHOUT, A. \& OSARIO, C.J. (1992). Full-scale application of the UASB technology for sewage treatment. Water Science and Technology, 5(7): 157-66.

SINGH, K.S. \& VIRARAGHAVAN, T. (2003). Impact of temperature on performance, microbiological, and hydrodynamic aspects of UASB reactors treating municipal wastewater. Water Science and Technology, 48(6): 211-217.

SMITH, P.H. \& MAH, R.A. (1966). Kinetics of acetate metabolism during sludge digestion. American Society for Microbiology, 14: 1980.

SPEECE, R.E. (1983). Anaerobic biotechnology for industrial wastewaters. Environmental Science \& Technology, 17: 416A-427A.

SPEECE, R.E. (1988). A survey of anaerobic sludge digesters and diagnostic activity assays. Water Research, 22(3): 365-372.

SPROUSE, G. \& RITTMANN, B.E. (1991). Colloidal removal in fluidized-bed biofilm reactor. Journal of Environmental Engineering, 116(2): 314-329.

STANDARD METHODS FOR THE EXAMINATION OF WATER AND WASTEWATER (2005). American Public Health Association, American Water Works Association, Water Environment Federation, $21^{\text {st }}$ edition, Washington D.C.

STAMS, A. J. M. (1994). Metabolic interactions between anaerobic bacteria in methanogenic environments. Antonie van Leeuwenhoek, 66: 271-294. 
STEINER, A.E.; McLAREN, D.A.; FORSTER, C.F. (1976). The nature of activated sludge flocs. Water Research, 10: 25-30.

STUMM, W. \& MORGAN, J.J. (1996). Aquatic Chemistry. John Wiley \& Sons, $3^{\text {rd }}$ edition, New York, USA.

SUTHERLAND, I.W. (1984). Microbial exopolysaccharides: their role in microbial adhesion in aqueous systems. CRC Critical Reviews in Microbiology, 10: 173-201.

SWITZENBAUM, M.S. \& JEWELL, W.J. (1980). Anaerobic attached-film expandedbed reactor treatment. Journal Water Pollution Control Federation, 52: 1953-1965.

TCHOBANOGLOUS, G. \& BURTON, F.L. (1991). Wastewater Engineering: Treatment, Disposal and Reuse. McGraw Hill Inc., $3^{\text {rd }}$ edition.

TEIXEIRA, A.R.; ALVES, C.V.P.; DE PAULA, F.S.; AQUINO S.F.; CHERNICHARO C.A.L. (2005). Influência do peneiramento forçado do esgoto bruto no desempenho de reator UASB tratando esgotos domésticos. In: Anais do $23^{\circ}$ Congresso Brasileiro de Engenharia Sanitária e Ambiental, Campo Grande, Brasil.

THIELE, J.H.; CHARTRAIN, M.; ZEIKUS, J.G. (1988). Control of interspecies electron flow during anaerobic digestion: role of the floc formation. Applied and Environmental Microbiology, 54: 10-19.

TILCHE, A. \& VIEIRA, M.M. (1991). Discussion report on reactor design of anaerobic filters and sludge bed reactors. Water Science and Technology, 24(8): 193-206.

TIWARI, M.; GUHA, S.; HARENDRANATH, C.; TRIPATHI, S. (2006). Influence of extrinsic factors on granulation in UASB reactor. Applied Microbiology and Biotechnology, 71(2): 145-154.

TORRES, P. \& FORESTI, E. (2001). Domestic sewage treatment in a pilot system composed of UASB and SBR reactors. Water Science and Technology, 44(4): 247253. 
UEMURA, S. \& HARADA, H. (2000). Treatment of sewage by a UASB reactor under moderate to low temperature conditions. Bioresource Technology, 72: 275-282.

URBAIN, V.; BLOCK, J.C.; MANEM, J. (1993). Bioflocculation in activated sludge: an analytic approach. Water Research, 27(5): 829-838.

van den BERG, L. \& KENNEDY, K.J. (1983). Dairy waste treatment with anaerobic stationary fixed film reactors. Water Science and Technology, 15(8/9): 359-368.

van den BERG, L. \& LENTZ, C.P. (1977). Food processing waste treatment by anaerobic digestion. Proceeding of the $32^{\text {nd }}$ Industrial Waste Conference, Purdue University, Lafayette, Indiana: 252-258.

van der LAST, A.R.M. \& LETTINGA, G. (1992). Anaerobic treatment of domestic sewage under moderate climatic (Dutch) conditions using upflow reactors at increased superficial velocities. Water Science and Technology, 25(7): 167-178.

van der MERWE M. \& BRITZE T. J. (1993). Anaerobic digestion of baker's yeast factory effluent using an anaerobic filter and a hybrid digester. Bioresource Technology, 43: 169-174.

van HAANDEL, A.; KATO, M.T.; CAVALCANTI, P.F.F.; FLORENCIO, L. (2006). Anaerobic reactor design concepts for the treatment of domestic wastewater. Reviews in Environmental Science and Bio/Technology, 5:21-38.

van HANDEL, A.C. \& LETTINGA, G. (1994). Anaerobic sewage treatment. In: A practical guide for regions with a hot climate. John Willey \& Sons Ltd., Chichester, UK.

van LIER, J.B.; TILCHE, A.; AHRING, B.K.; MACARIE, H.; MOLETTA, R.; DOHANYOS, M.; HULSHOFF POL, L.W.; LENS, P.; VERSTRAETE, W. (2001). New perspectives in anaerobic digestion. Water Science and Technology, 43(1): 118. 
van ROMPU, K.; D'HAENE, S.; VERSTRAETE (1990). Mass transport in anaerobic polyurethane carrier reactor. Process Biochemistry, 25(1): 3-6.

VARESCHE, M.B.; ZAIAT, M.; VIEIRA, L.G.T.; VAZOLLER, R.F.; FORESTI, E. (1997). Microbial colonization of polyurethane foam matrices in horizontal-flow anaerobic immobilized-sludge reactor. Applied Microbiology Biotechnology, 48: 534-538.

VAVILIN, V.A.; RYTOV, S.V.; LOKSHINA, L.Y. (1996). A description of hydrolysis kinetics in anaerobic degradation of particulate organic matter. Bioresource Technology, 56(2-3): 229-237.

VIEIRA, S.M.M. (1988). Anaerobic treatment of domestic sewage in Brasil - Research results and full-scale experience. In: Vieira et al. (Eds). Proceedings of the $5^{\text {th } I n t e r n a t i o n a l ~ S y m p o s i u m ~ o n ~ A n a e r o b i c ~ D i g e s t i o n . ~ P e r g a m o n ~ P r e s s, ~ N e w ~ Y o r k: ~}$ 185-196.

von SPERLING, M. \& CHERNICHARO, C.A.L. (2001). Performance evaluation of a UASB-activated sludge system treating municipal wastewater. Water Science and Technology, 43(11): 323-328.

WANG, K. (1994). Integrated anaerobic and aerobic treatment of sewage. Ph.D. Thesis. Department of environmental technology, Wageningen University, Wageningen, The Netherlands.

WANG, K.; ZEEMAN, G.; LETTINGA, G. (1995). Alteration in sewage characteristics upon aging. Water Science Technology, 31(7): 191-200.

WIEGANT, W.M. (2001). Experience and potential of anaerobic treatment in tropical regions. Water Science Technology, 44(8): 107-113

WIRTZ, R.A. \& DAGUE, R.R. (1997). Laboratory studies on enhancement of granulation in the anaerobic sequencing batch reactor. Water Science Technology, 36: 279-286. 
WOESE, C.R. \& FOX, G.E. (1977). Phylogenetic structure of the prokaryotic domain: the primary kingdoms. Proceedings of the National Academy of Sciences of the United States of America, 74: 5088-5090.

YOUNG, J.C. (1991). Factors affecting the design and performance of upflow anaerobic filters. Water Science and Technology, 24(8): 133-155.

YOUNG, J.C. \& DAHAB, M.F. (1983). Effect of media design on the performance of fixed-bed anaerobic reactors. Water Science amd Technology, 15(8/9): 369-383.

YOUNG, J.C. \& McCARTY, P.L. (1969). The anaerobic filter for waste treatment. Journal Water Pollution Control Federation, 41(5): 160-173.

ZAIAT, M. (1996). Development of horizontal-flow anaerobic immobilized sludge (HAIS) reactor for wastewater treatment. Ph.D. Thesis. Escola de Engenharia de São Carlos, Universidade de São Paulo.

ZAIAT, M. (2003). Desenvolvimento e análise de biorreatores anaeróbios contendo células imobilizadas para tratamento de águas residuárias: reator anaeróbio horizontal de leito fixo reator anaeróbio operado em bateladas sequenciais. Texto (Livre Docência). Escola de Engenharia de São Carlos, Universidade de São Paulo.

ZAIAT, M.; CABRAL, A. K. A.; FORESTI, E. (1994). Reator anaeróbio de leito fixo para tratamento de águas residuárias: concepção e avaliação preliminar de desempenho. Revista Brasileira de Engenharia - Caderno de Engenharia Química, 11: 33-42.

ZAIAT, M.; CABRAL, A.K.A.; FORESTI, E. (1996). Cell wash-out and external mass transfer resistance in horizontal-flow anaerobic immobilized sludge (HAIS) reactor. Water Research, 10: 2435-2439.

ZAIAT, M.; PASSIG, F.H.; FORESTI, E. (2000). Treatment of domestic sewage in horizontal-flow biomass reactor. Environmental Technology, 21(10): 1139-1145. 